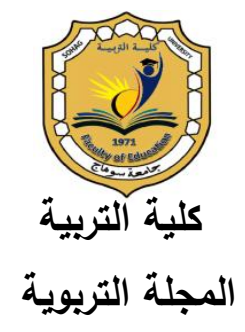

\title{
أساليب المعاملة الوالدية وعلاقتها بالتفكير الابتكاري لدى التلاميذ الموهوبين ذوي صعوبات التعلم
}

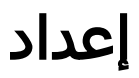 \\ د د سهى بلدوي محمل منصور \\ أستاذ مساعد التريية الخاصة- كلية العلوم واللاراسات الإنساتية \\ جامعة الامام عبد الرحمن بن فيصل - المملكة العربية السعودية
}

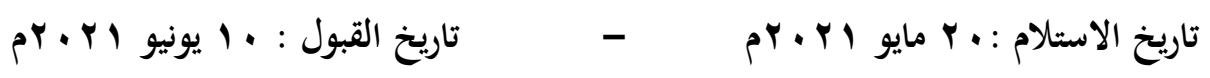

\section{DOI: 10.12816/EDUSOHAG.2021.}


المستخمص

هدفت هذه الدراسة للتعرف العلاقة بين أساليب المعاملة الوالدية وعلاقتها بالتفكير الابتكاري لاي التلاميذ الموهوبين ذوي صعويات التعلم ، واعتمدت الدراسة على استبيان أساليب المعاملة الوالدية ، واستبيان التفكير الابتكاري لاى الموهوبين ذوي صعويات التعلم

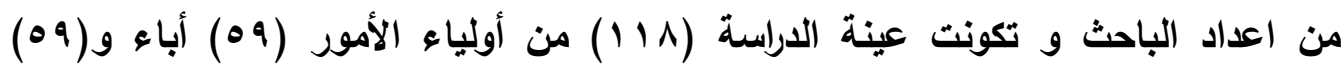
امهات ، لأجمالي(ه) طقل من الموهوبين ذوي صعويات التعلم والذين تم تثخيصهم باستخدام اختبارات التشخيص لمستويات الأداء والإنجاز في المجالات الأكاديمية ذات لمات

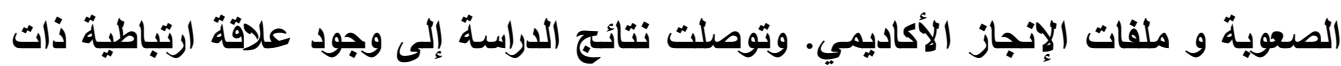
دلالة إحصائية بين الأساليب الايجابية المتمثلة في(أسلوب الايمقراطية، أسلوب التشجيع والمكافأة ) وبين ارتفاع مستوي التفكير الإيجابي لدى الأبناء من التلاميذ ذوي صعويات التعلم ، ووجود علاقة ارتباطية عكسية ذات دلالة إحصائية بين الأساليب السلبية (القسوة والتسلط الإبنائ ، إثارة الألم النفسي) وإنخفاض مستوي التفكير الابتكاري لاي الأبناء وكاتت أكثر أساليب التهابله

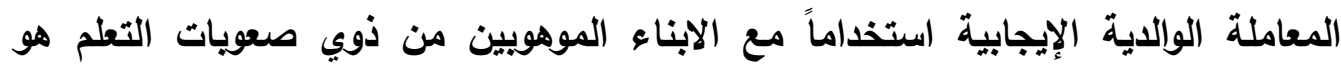
أسلوب (التشجيع والمكافأة ، التقبل والاهتمام ، الديمقرطية) أما في الأساليب السلبية فكاتت أكثر الأساليب استخداماً هو أسلوب (النبذ، الحماية الزائدة).

الكلمات المفتاحية: أساليب المعاملة الوالدية - التفكير الابتكاري - الموهوبين ذوي صعويات التعلم 


\title{
Parental treatment styles and its relationship to creative thinking among gifted students with learning difficulties
}

\begin{abstract}
This study aimed to identify the relationship between parental treatment styles and its relationship to creative thinking among gifted with learning difficulties students. The study relied on a questionnaire on parenting styles and to creative thinking among gifted with learning difficulties students prepared by the researcher. The study sample consisted (118) of parents (59). ) fathers and (59) mothers, and the results of the study concluded that there is a statistically significant correlation between the positive methods represented in (democracy style, encouragement and reward style) and the high level of positive thinking among children of students with learning difficulties, and the presence of a significant inverse correlation A statistic between the negative methods (cruelty and bullying, provoking psychological pain) and the low level of innovative thinking among the children. The most used positive parental treatment methods with gifted children with learning difficulties was (encouragement and reward, acceptance and attention, democracy), while in the negative methods it was the most Commonly used is the (untouchability, overprotection) method.
\end{abstract}

Key words: Parenting Styles-Creative Thinking- Gifted with Learning Disabilities 


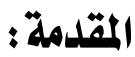

تعتبر التنشئة الاجتماعية من أهم العمليات الاجتماعية التي تسهر على بناء شخصية

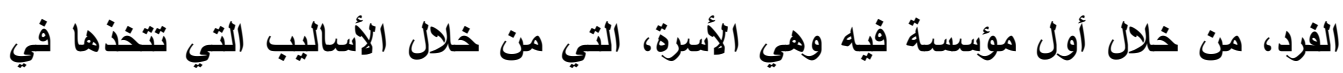

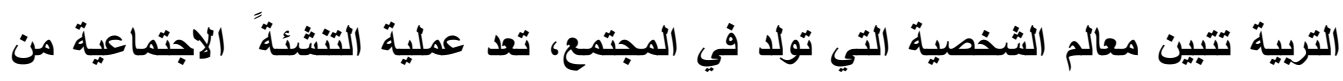

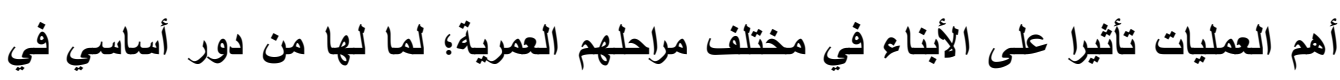

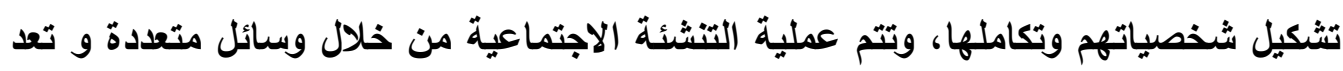

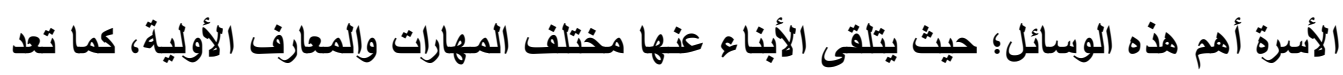

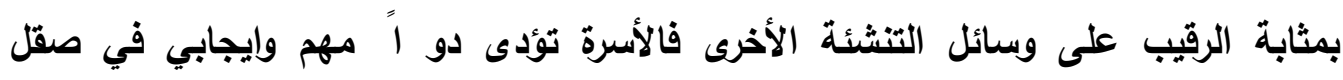

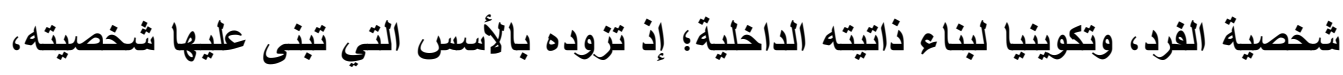

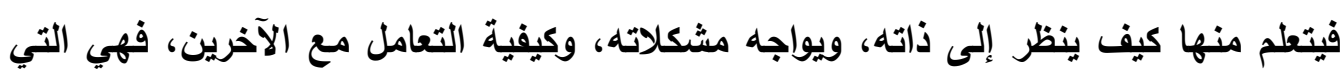

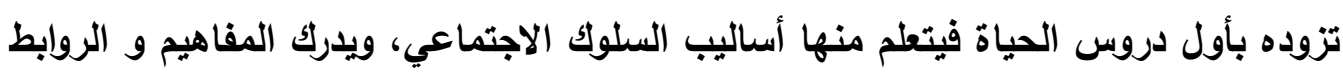

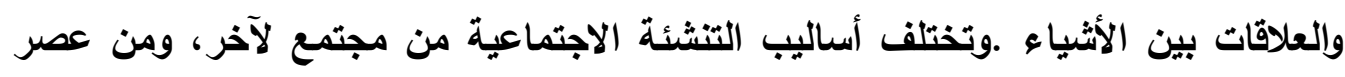

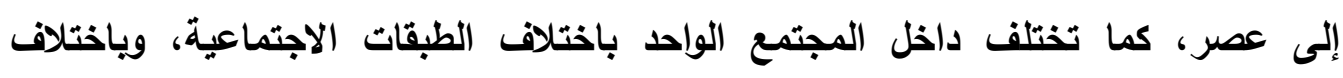

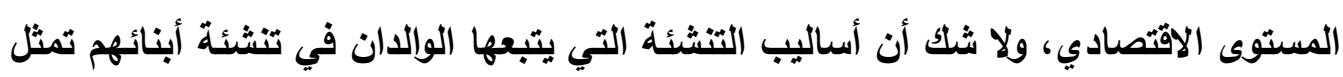

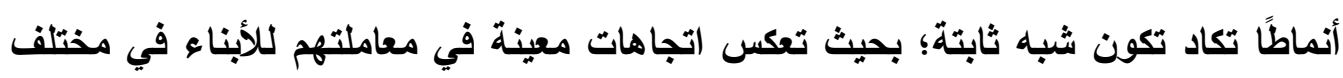

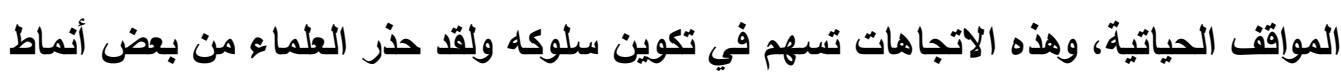

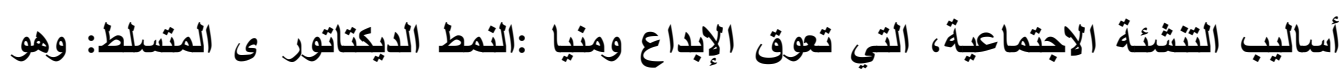

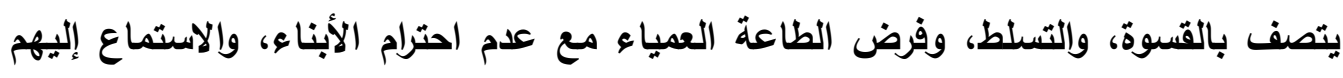

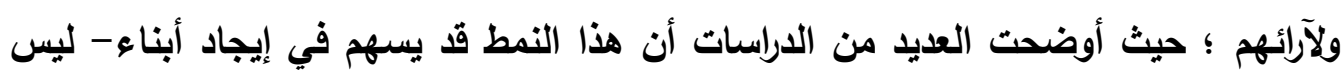

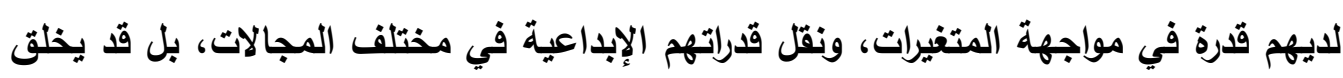

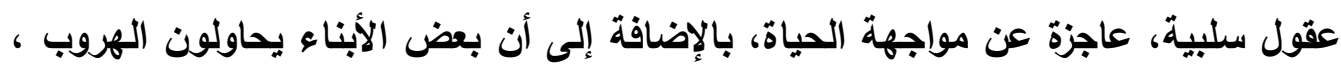

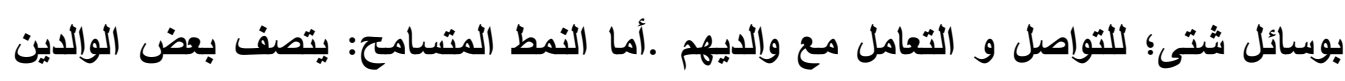

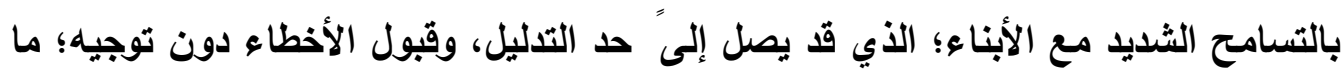

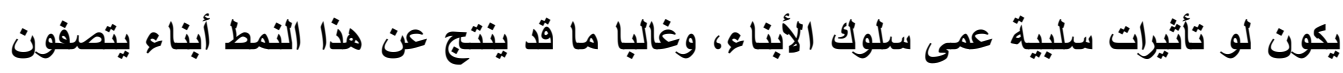
بالفشل والانحراف، وغير قادرين على تكوين علاقات اجتماعية سوية .في حين أن الأسرة

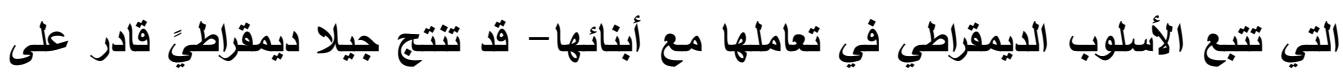


تحمل المسؤولية وتعزز ثقتهم بأنفسهم، وتكيف شخصياتهم، وتمكنهم من مجابهة المواقف المتعدة التي يمرون ن بها خلال مراحل تكوينهم. وتعد الأسرة أحد أهم الركائز في إظهار موهبة الطقل وقدراته الشخصية ،وتقديمها إلى هراتى المجتمع ، فهي اللبنة الأولى التي ينمو فيها هذا الطفل ،وتلعب دورا محوريا في عملية تظوير مهاراته واستعداداته ؛ وتعد البوصلة التي ترصد اكتثافات هذه المواهب ومعارفهم و فنياتهم ، والأخذ بأيديهم وتقديم لهم جميع أساليب الرعاية التريوية والصحية السليمة من أجل هل المحافظة على إبداعهم وتفوقهم ؛ لكنها تعجز أحيانا لعوامل عدة أهمها غياب الوعي ، إضافة إلى نقص الخبرة ، وقلة التدريب، أو عوامل خارجية أخرى كنقص اهتمام الدولة بهذه الفئة كعجزها على إنشاء مدارس الخاصة لهم ونقص الكفاعات العلمية وعدم ملائمة مناهجها الدراسية مع قدراتهم وإمكانياتهم ، لذلك يعد دور الأسرة والمجتمع دورا مهما في نهوض أو مدأ خمود مواهب وتفوق هذه الفئة ومن هذا المنطلق كرس العديد من المربين والمتخصصين والباحثين جهودهم لرعاية هذه الثريحة الاجتماعية أمثال "هولنجوث" و"تيرمان" و "بنيه" والبرازيلية هلينا أنتوف "وغيرهم....... ، وسعت هذه الجهود إلى رصد قيمة الموهويين وفاعليتهم داخل مجتمعاتهم وذلك من خلال دراسة مختلف جوانبهم الثخصية كالعقلية والجسمية والمعرفية والنفسية والاجتماعية وقد ركز الاتجاه العالمي نحو التعليم الثامل على هلى الطلاب الذين يعانون من مجموعة واسعة من الإعاقات الذين يتم تعليمهم في المدارس العادية، لكنه تجاهل حتى الآن أولئك الذين لديهم مواهب أو مواهب مختلفة بالإضافة إلى دئ سلى إعاقاتهم. من السهل نسبيًا تحديد الطلاب الموهوبين والمتفوقين الذين تنعكس قدرتهم على هلى الأداء العالي في مختلف مقاييس الإنجاز التعليمي أو في مجموعة من أنواع الأنشطة الفنية

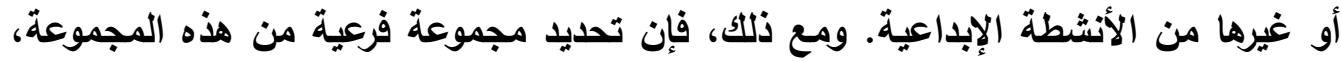

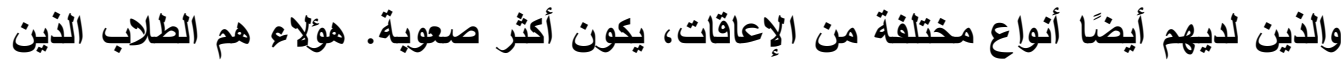
يُعتبرون لايهم استثناءات مزدوجة أو متعددة، أو يُطلق عليهم اسم ذوي صعويات تعلم Coleman, el ) الموهويين، أو يشار إليهم بمفهوم الأطفال مزدوجو الاستثنائية (al.,2015) ، ويمكن تعريف هؤلاء التلاميذ بأنهم " المتعلمون المتميزون مرتين وهم الذين يظهرون إمكانات تحقيق عالية أو إنتاجية إبداعية في مجال واحد أو أكثر مثل الرياضيات أو داء

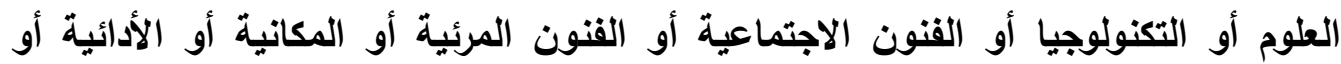


غيرها من مجالات الإنتاجية البشرية ومن نظهر إعاقة واحدة أو أكثر على النحو المحدد في

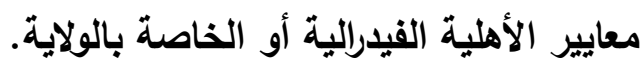

(Reis, el al.,2014)

ويعتبر الطلاب مزدوجو الاستثنائية عندما يتم تحديدهم على أنهم موهويون في مجال واحد أو أكثر بينما يعانون أيضًا من إعاقة في التعلم أو في الجوانب العاطفية أو الجسدية أو مرئ

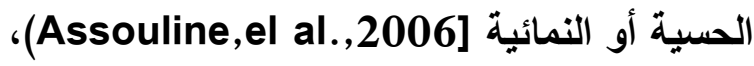

(Yewchuk, el al.,1993)

ويعد تعليم التفكير أحد المجالات المهمة في تكوين شخصية الطالب، إذ إن الهدف الأسمى للتربية هو إعداد المواطن ليصبح أكثر فاعلية في مجتمعه وأكثر قدرة على تلبية متطلبات مراحل العمر المختلفة، لذلك حينما يدرب الطالب على إدارة العمليات الذهنية وزيادة سرعتها لكي يستطيع مواكبة التطور المعرفي والتكنولوجي، فإنتا نسهم في تثكيل شخصية

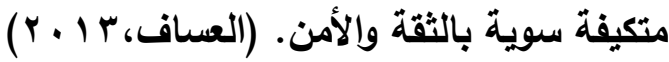
ولعل من بين الأسباب التي دفعت إلى إجراء الدراسة الحالية هو التركيز على شريحة مهمة في المجتمع ولبنة أساسية في تنميته وازدهاره، وذلك من خلال معرفة الأساليب الأسرية المتبعة مع هذه الفئة وتأثيرها على شخصية الطقل، ومحاولة تحديدها وخاصة السوية منها التي تساعده على إبراز مواهبه وتكوينه وتوجهيه لمواجهة متطلبات الحياة

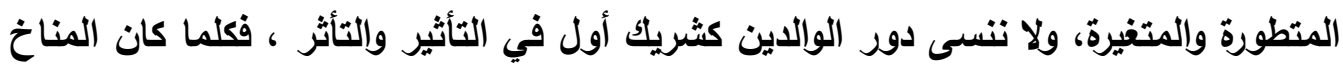
الأسري مشجع ومحفز على التفوق والإبداع ، وملبي لاحتياجاته الأساسية لتنمية و تطوير قدراته الفائقة وتوظيفها جعله أكثر فاعلية في المجتمع. ولذا يجب على الوالدين العمل على تشجيع ابنهم الموهوب (المتفوق) على التعبير عن ذاته بكل حرية واستقلالية وإظهاره خبراته وتجاريه، و مرافقته والسهر على تعليمه وتدريبه

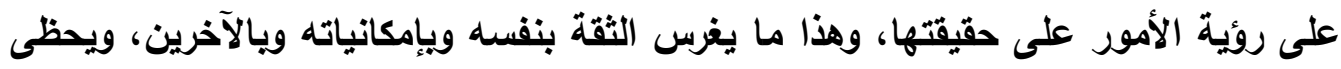
بقبول وتقدير اجتماعي مما يساهم في علاج المشكلة الرئيسة عنده وهي صعوية التعلم ، ويتطلب هذا حزمة من المجهودات التريوية والنفسية .من أجل تقديم ما لايه من استعدادات وخبرات تفيد أسرته ومجتمعه، وذلك بالحرص على مراعاة أساليب المعاملة التي يتبعها الآباء 
مع أبنائهم سواء كانوا موهوبين فقط او موهوبين ذوي صعويات واجتناب جميع الأساليب السلبية .

ومن هنا جاءت الحاجة إلى اجراء الدراسة الحالية لتوضح العلاقة بين أساليب

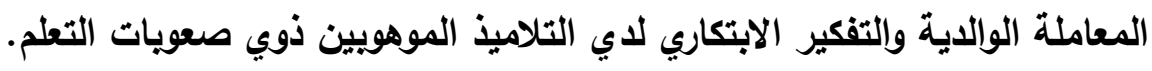

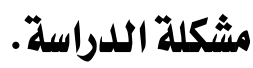

أكلت بعض الدراسات على أهية دور اساليب المعاملة الوالدية السوية في تنمية

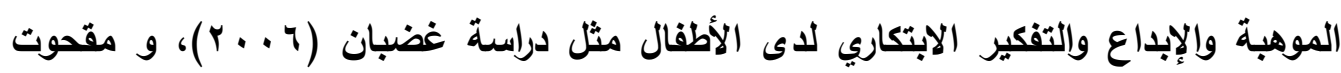

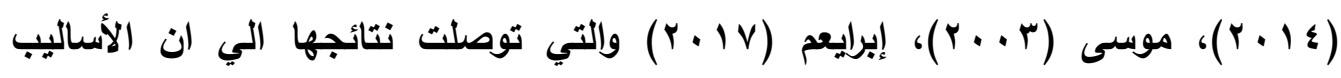

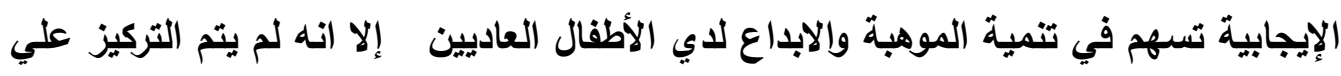

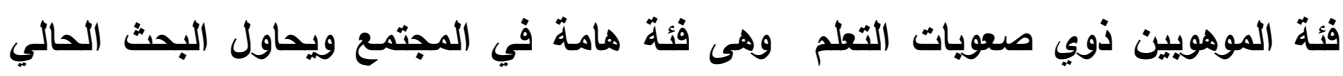

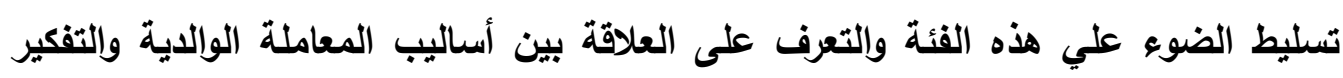

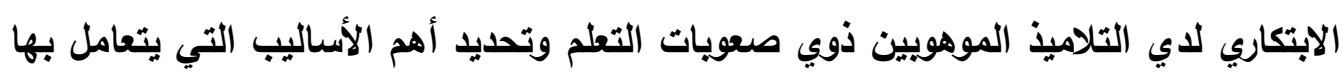

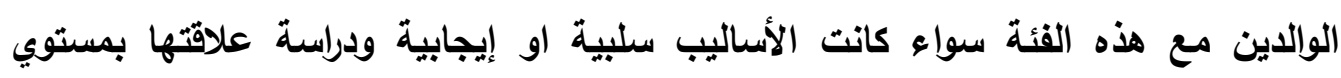

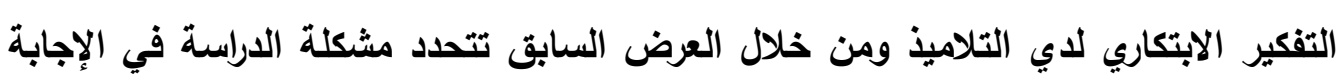
عن التساؤلات الاتية : الايكائ - هل هل توجد علاقة ذات دلالة إحصائية بين أساليب المعاملة الوالاية ومستوى التفكير

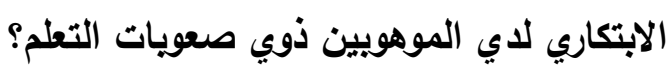

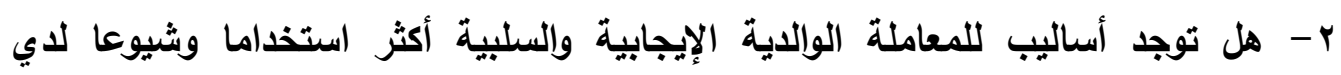

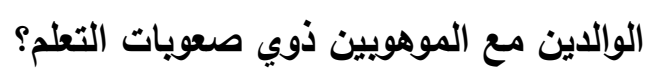
r- هل توجد فروق ذات دلالة إحصائية بين كلا من الاب والام في استخدام الاساليب

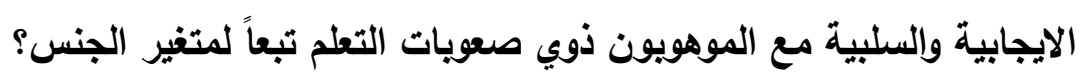

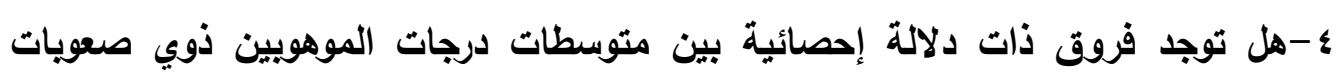

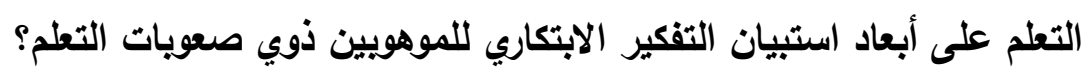




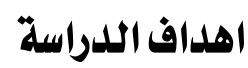

1- التعرف على العلاقة بين أساليب المعاملة الوالاية ومستوى التفكير الابتكاري لاي الموهوبين ذوي صعويات التعلم.

r- التعرف على أساليب المعاملة الوالدية الإيجابية والسلبية الاكثر استخداما وشيوعا لاي الوالدين مع الموهوبين ذوي صعويات التعلم؟ ץ-التعرف على الفروق بين كلا من الاب والام في استخام الاساليب الايجابية والسلبية مع دعائ

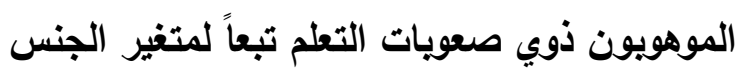
§ - التعرف على الفروق بين متوسطات درجات الموهوبين ذوي صعويات التعلم على أبعاد استبيان التفكير الابتكاري للموهوبين ذوي صعوين التوبيات التعلم أهمية الدراسة تستمد الدراسة الحالية أهميتها بتناول فئة الموهوبين ذوي صعويات التعلم بالدراسة

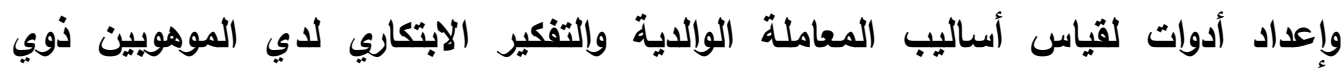
صعوبات التعلم وتعد هذه المتغيرات جانباً هاماً سواء من الناحية النظرية أو التطبيقية.

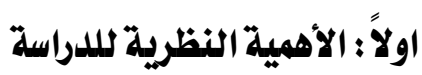
- تكمن أهمية الدراسة نظرياً في تناول فئة الموهوبين ذوي صعويات التعلم وأساليب المعاملة الوالدية الإيجابية والسلبية التي تؤثر على التفكير الابتكاري لاي هذه الفئة حيث أن فئة

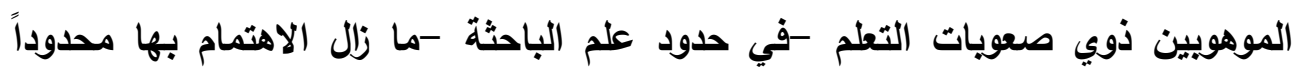
ويقتصر على قضايا الكثف والتثخيص. - ضرورة الاهتمام بمهارات التفكير الابتكاري حيث انها من المتغيرات التي قد يؤدي الاهتمام بها ويتنميتها الى حل المشكلة الرئيسة لاى هذه الفئة وهي صعويات التعلم ثانياً الأهمية التطبيقية للدراسة - تصميم الأدوات من خلال: استبيان لقياس أساليب المعاملة الوالدية واخر لقياس التفكير الابتكاري لاي الموهوبين ذوي صعويات التعلم 
- حث الوالدين للاستفادة من نتائج الدراسة في تركيز الوالدين على استخام الأساليب

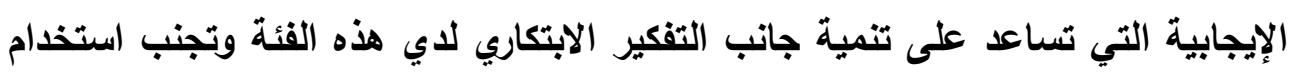

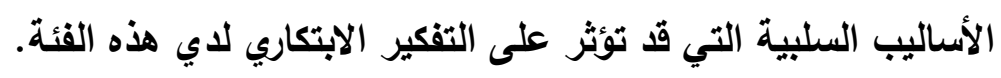

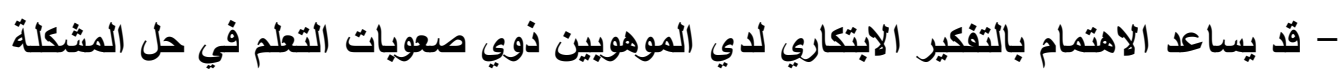
الرئيسية لديهم وهي صعويات التعلم.

مصطلحات الدراسة

التعريف الاجرائي لأساليب المعاملة الواللدية

هي الأساليب التي يستخدمها الوالدين بقصد تثكيل وتعديل سلوك الأبناء أو الوالئ تنمية هذا السلوك بما يتمشى مع معايير وقيم المجتمع واستثارة القدرات الابتكارية

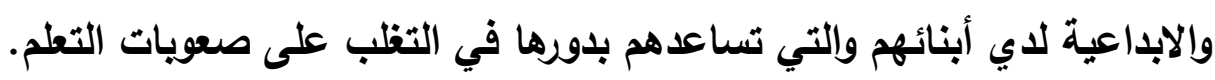
التعريف الاجرائي للتفكير الابتكاري

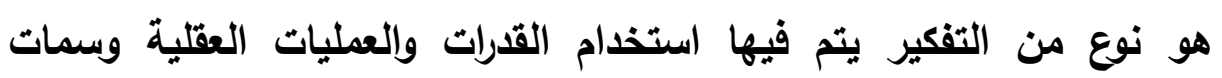
الثخصية لاكتشاف المواهب والمعارف والفنيات التي تيسر عملية الابتكار وخلق أفكار جليدة تساعد الطفل علي صقل مهاراته وحل مشكلاته. التعريف الاجرائي للموهوبين ذوي صعوبات التعلم هم التلاميذ الذين تم تثخيصهم رسمياً من قبل وزارة التربية والتعليم السعودية تبعاً

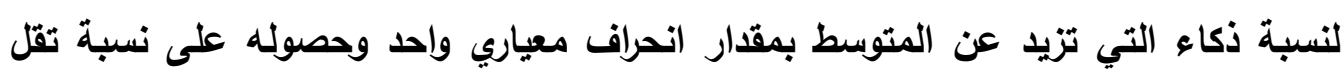
على ( • \%\%) بالتحصيل الداسي من مادة لمادتين على الأقل.

\section{محدذات الدراسة أنة}

حدود موضوعية: تناولت الدراسة أساليب المعاملة الوالدية كما يدركها اولياء أمور

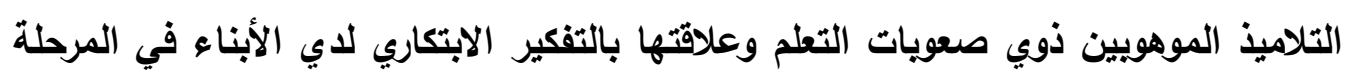
الابتدائية.

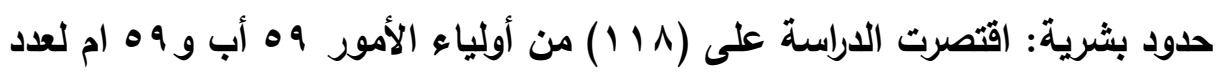
(9ه) طقل من الأطفال الملتحقين بالمدارس الابتدائية بمدينة الجبيل في المملكة العربية

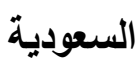


حدود زمانية: اقتصر تطبيق الدراسة في الفصل الثاني من العام الدراسي $\cdot r \cdot r / / r \cdot r \cdot$.

حدود مكانية: تم تطبيق الدراسة على أولياء امور الطلبة الموهوبين ذوي صعويات التعلم الملتحقين بالبرامج الخاصة في مدارس المرحلة الابتائية (الابتدائية الثامنة والسادسة والثالثة عشر والخامسة عشر) في مدينة الجبيل في المملكة العربية السعودية.

الإطار النظري

\section{أولاً: أساليب المعاملة الواللية Parental treatment styles}

مفهوم أساليب المعاملة الواللدية

تعرف أساليب المعاملة الوالدية بانها" هي تلك الطرق التي يتبعها الوالدان في معاملة ابنائهما خلال عملية التنشئة الاجتماعية التي تحدث التغيير والتي تؤثثر أثثير سلباً او إيجاباً على سلوك الطقل من خلال استجابة الوالدين السلوكية"

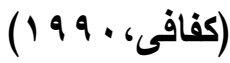

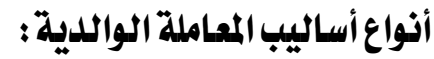
تعددت أنواع أساليب المعاملة الوالدية من عالم إلى أخر كل حسب وجهة نظره وهذا

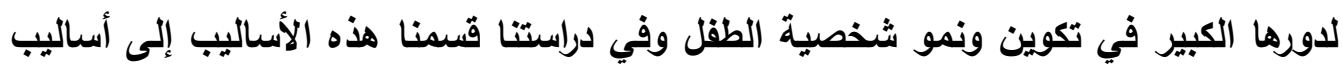

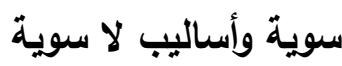
الأساليب السوية :وهي مجموعة من الأساليب الإيجابية التي يمارسها الآباء أثناء التعامل مع أبنائه بهدف تحقيق التوازن النفسي والاجتماعي لهم، وتطبيعهم بالأنماط الاطياء السلوكية المقبولة اجتماعيا وقيما وأخلاقيا. وتتمثل هذه الأساليب فيما يأتي: الأسلوب الايمقراطي: هو البعد عن فرض النظام الصارم على الأطفال والتثاور معهم

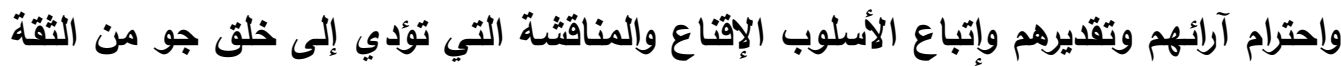

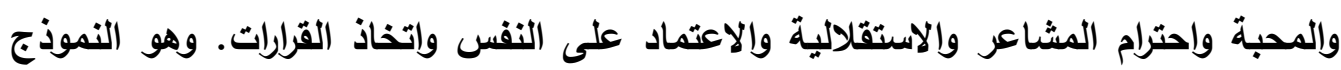

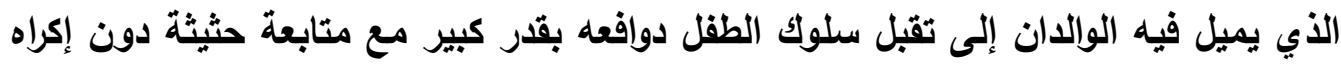
واحترام شخصية الطفل وارداته وتوجيه سلوكه وهما لا يريان في تربية الطفل مهمة صعبة الطبل

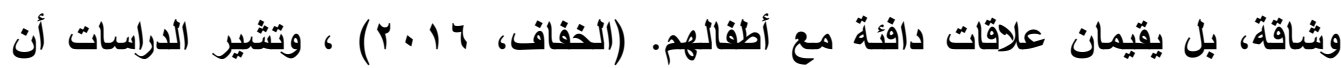


استخدام الأسلوب الايمقراطي من قبل الوالدين في تربية أبنائهم، يؤثثر بطريقة ملحوظة على

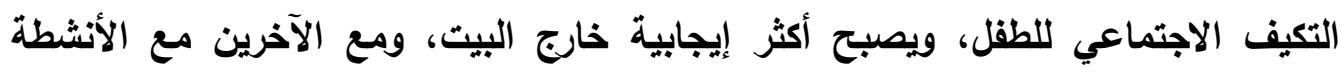

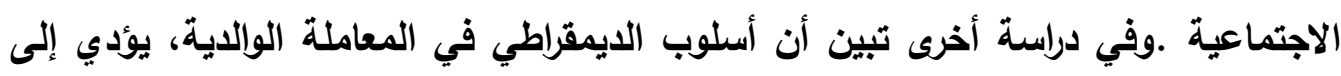
زيادة إنتاجية الأبناء، ويكونون اقل اعتداء على الممتلكات الغير وأكثر مواظبة وأكثر اعتمادية

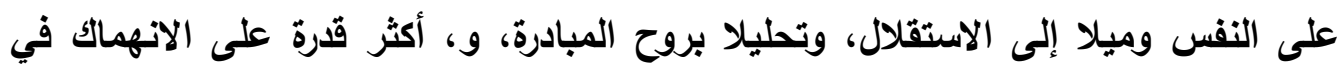
نشاط عقلي تحت ظروف صعبة، أكثر اتصافا بالود، أقل عدوانية وأكثر أصالة وتلقائية

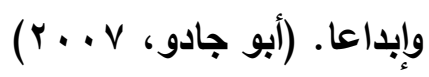

أسلوب التقبل :يعد هذا الأسلوب من الأساليب المعاملة الوالدية الصحيحة ويتمثل في

الحب القاطع من الأبوين للطقل والاستعدادات لرعايته واحتضانه في الأسرة والتهيؤ الاستجابة الاسبة

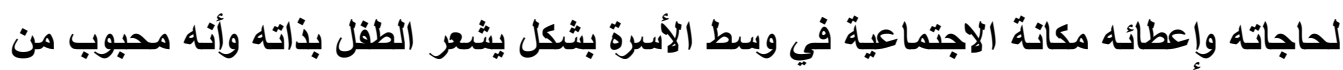
قبل واللايه ويشير "سيمونذر" في دراسة له إن القبول الاجتماعي للطفل في الأسرة له مظاهره وتتمثل في اهتمام الوالدين بتنشئة الطقل وفي رعايته والمحافظة عليه والاهتمام بمستقبله والتخطيط له وتثجيعه وكذلك يشعرون الطقل بالحب والحنان والاحترام ويشركانه في أنشطة

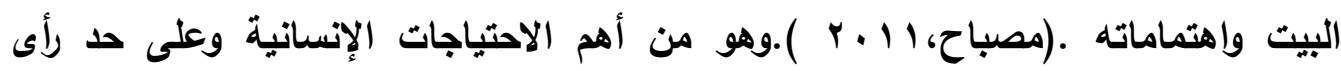

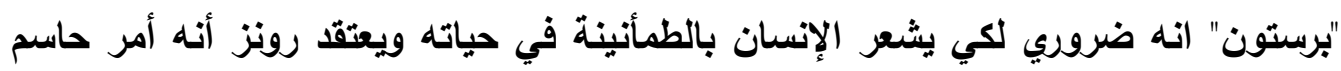
في نموه الثخصية، يترتب عليه آثار تنعكس سلوك الأبناء ونموهم وأدائهم الوظيفي وتقديرهم الإيجابي لأنفسهم ونظرتهم الإيجابية للحياة في مرحلة الرشد ويؤيد ذلك الرأي هرون وزملائه

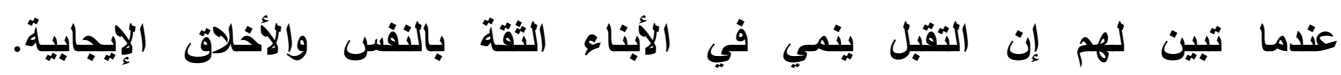

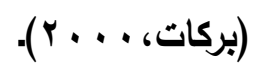

أسلوب التشجيع :وهو يعني على حرص الوالدين تشجيع أبنائهم على أداء الأعمال

الموكلة إليهم وإتقانها وتحفيزهم باستمرار على النجاح في المدرسة وفي الحياة العامة. ولهذا

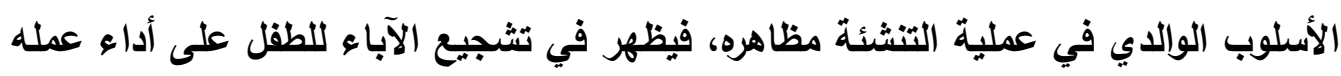
مهما كان صعبا، ورفع معنوياته، وتجديد ثقته في نفسه وفي قدراته الذاتية، ومساعدته بالإمكانيات التي تمكنه من ذلك، وكما يظهر هذا الأسلوب في اهتمام الوالدين بإنجازات الطقل

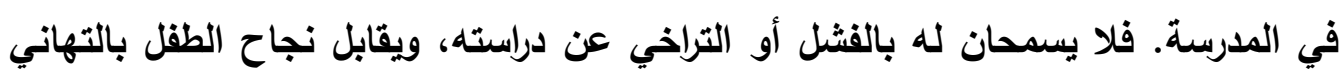


والفرح والجوائز والمكافئات، حتى يحافظ عليه، كما يشجع الآباء باستمرار الأبناء على أن تكون لهم أنشطة متعددة خارج المدرسة. (مصباح، 11 ـ بـ) . أسلوب المساواة والعدل :ويقصد بها توخي العدل في معاملة الأبناء وعدم المفاضلة

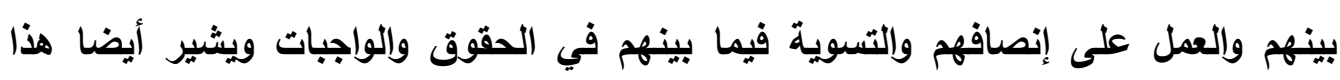

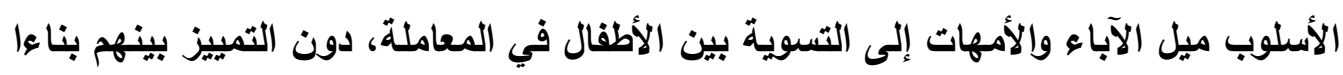

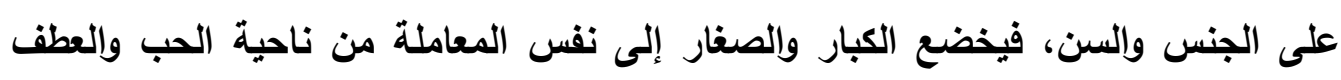
والمكافئة والمعاقبة والتشجيع والتثبيط ويخضع الجميع إلى نفس الأوامر والتوجيهات ولا

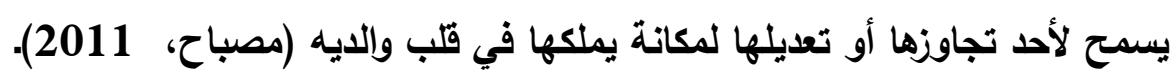

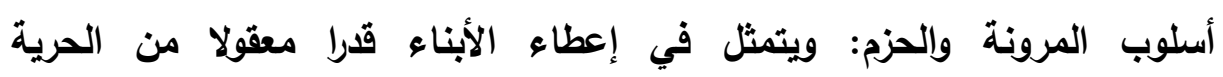

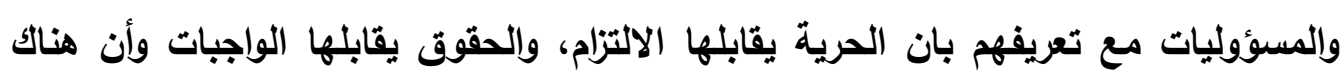

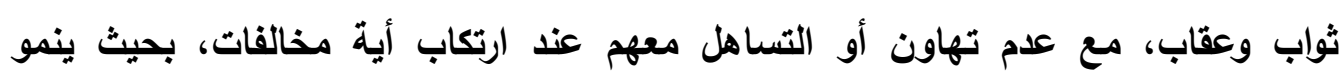

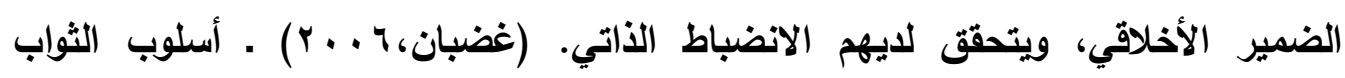
والمكافأة :الثواب والمكافأة المتوقعة المقرة للعمل المقبول قد تكون حاجة الأفئ غير مادية كالكلمة الحلوة أو الابتسامة والههمة الحانية أو النظرة الحنون، وقد تكون تصفيقا أو الو استحسانا

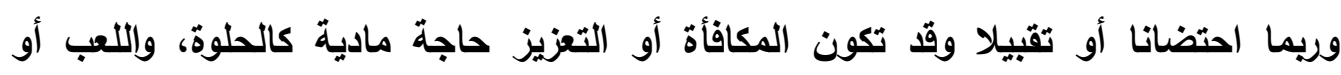

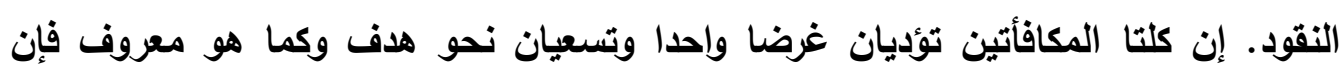
للمكافأة دورا هاما في دعم السلوك (موسى، ب . . ب). الأساليب اللاسوية :وتتمثل في الأساليب الخاطئة التي يتبنونها الوالدين أثناء التعامل

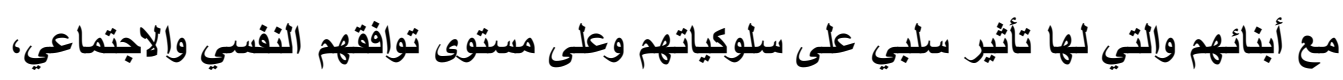
وتتمثل فيما يلي : ابناتهم ولئي أسلوب الحماية الزائدة :وهو حماية الطقل بشكل غير مناسب بحيث يمنع الطقل من

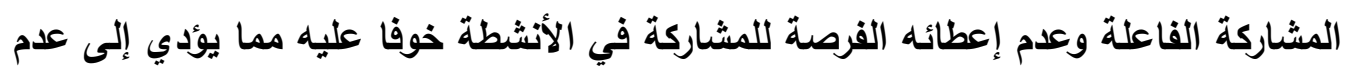

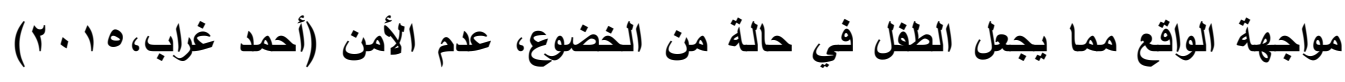

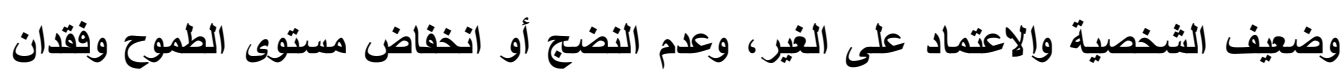

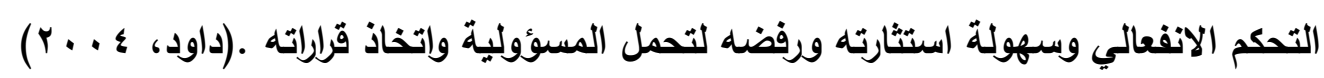


أسلوب الإهمال الزائد :يقصد به ترك الطقل دون تشجيع على السلوك المرغوب، او

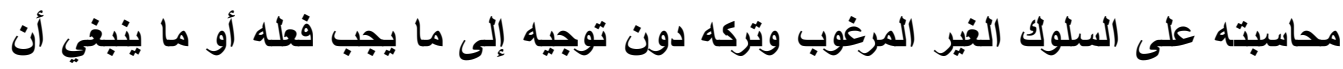
يتجنبه وقد يكون السبب في إهمال الوالدين هو عدم قرتهم على تعليم أطفالهم احترام السلطة وإتباع القواعد الاجتماعية، أو بسبب الطلاق أو موت احدهما، ويالتالي لا يتزود

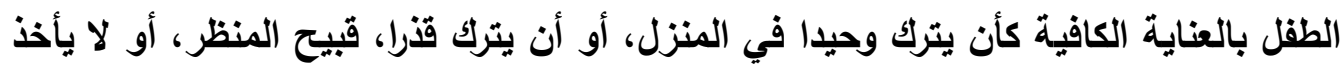

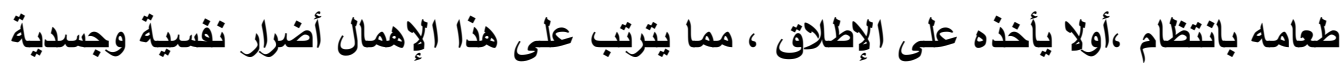

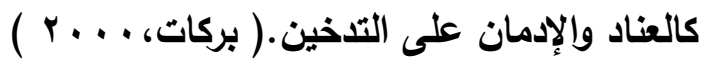
أسلوب القسوة :ويعد هذا الأسلوب من الأساليب التريوية الخاطئة التي يتبعها الآباء لضبط سلوك أبنائهم الغير مرغوب فيه ، ويتضمن العقاب الجسمي كالصفع والضرب، وكل ما يؤدي إلى إثارة الألم الجسدي وقد يكون مصحويا بالتهديد اللفظي أو الحرمان وقد تصل شدة

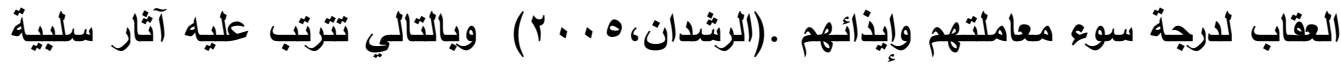
على معنويات الأبناء وتذكرهم دائما بمدى عنف الآباء مهما كانت الأسباب الداعية إلى تلك لكابل

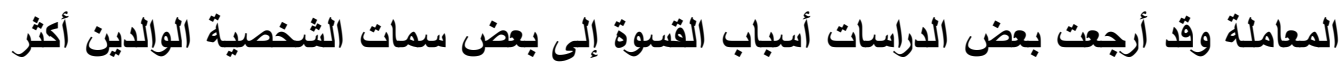

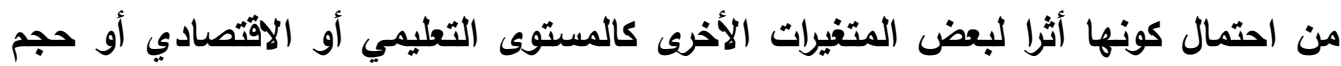

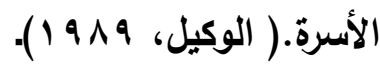
أسلوب التدليل الزائد :يعني إشباع كل رغبات الطقل إثباعا فوريا دون تأجيل، إثباعا عاطفيا وماديا بشكل مبالغ فيه، وعدم كف الطفل عن السلوك غير المرغوب فيه،

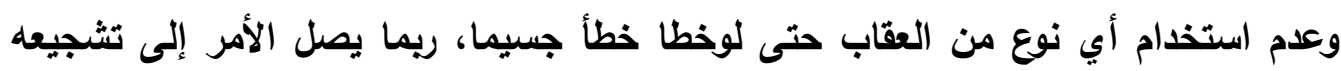
لمزيد من التجريب، بحيث ينتج عن هذا الأسلوب طقل غير قادر على تحمل المسؤولية، وكثير الاعتماد على الغير، وعدم تحمل مواقف الفشل والإحباط في الحياة الخارجية، ونمو

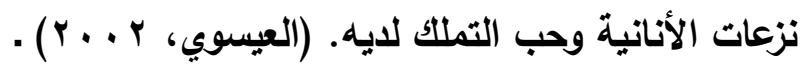
أسلوب التذبذب :ويقصد به التردد وعدم الوضوح الهدف وغموض الغاية وعدم

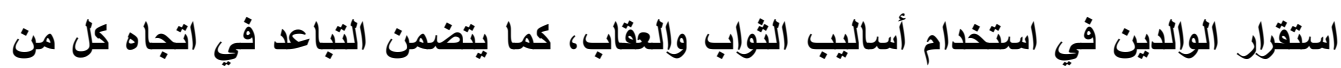
الوالدين في عمليات التنشئة وهذا كله يجعل الطفل في حيرة أمره دائم القلق وغير مستقر

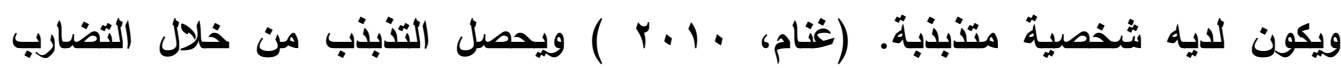
والتناقض في أساليب المعاملة التي تصدر عن الآباء والأمهات مع وأبنائهم في أي موقف ولف 
من حياتهم ، سواء كان نوعية الأساليب أو عدم الاتزان في السلطة بينهما، ويظهر ذلك غي محاسبة الأبناء على موقف معين، ثم عدم محاسبتهم على الموقف نفسه مرة أخرى، أوفي

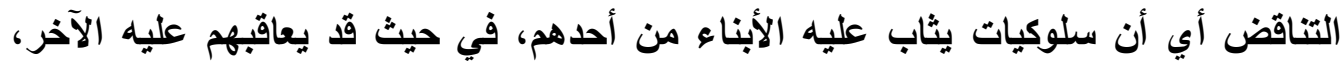

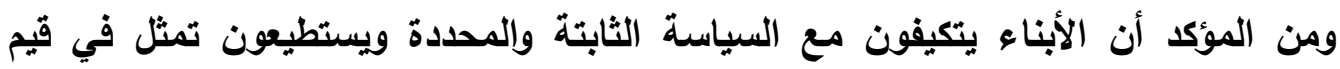
المجتمع ولكنهم يجدون صعوية في التكيف مع أساليب المتغيرة وغير متوقعة ما قد يؤدي إلى الى الى سوء التوافق والانحراف (المقاطي، 2018) أسلوب التفرقة :يتمثل في عدم المساواة بين الأبناء جميعا والتفضيل بينهم بسبب الجنس والسن أو ترتيب والسن أو غيرها نجد بعض الأسر تفضل الأبناء الذكور على الإناث

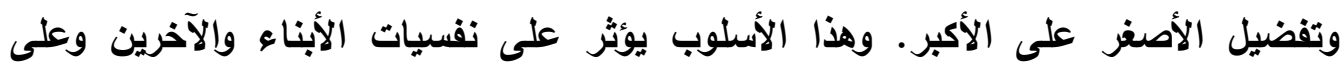
شخصياتهم فيشعرون الحقد والحسد اتجاه هذا الدفضل وينتج عنه شخصية أنانية (جراح، 2012) والغيرة الثديدة بين الأخوة، والثعور بالظل لاى الأبناء الأقل تفضيلا والصراع بين

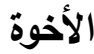

أسلوب التسلط :يعرف التسلط بأنه محاولة الوالدين التأثير على سلوك الأبناء للتصرف وفق أهواء، ورغبات، واتجاهات الوالدين وميولهم بغض النظر عن صحة ذلتك

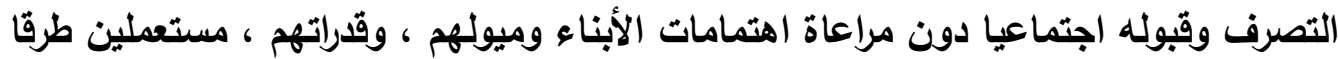
مختلفة من الإمتاع لفرض رأي، مثل التثجيع، والعقاب والتهايد لدرجة تطمس معهاعيا شخصية الطفل وحقه في إبداء رأيه ويتميز هذا الأسلوب بالضبط الصارم، وإيقاع العقاب المتكرر،

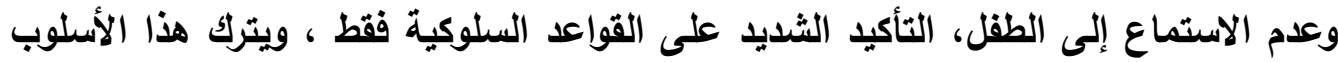
آثار على سلوك الطقل تتمثل في شعور بالتعاسة والانسحاب وعام الثقة في الآخرين،

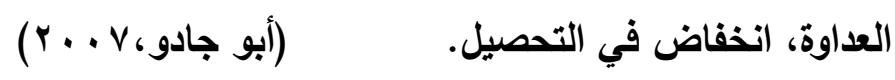

أسلوب إثارة الألم النفسي :ويتمثل هذا الأسلوب في جميع الأفعال التي تعتمد على

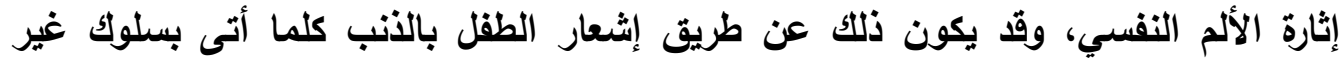
مرغوب فيه، كما يكون ذلك عن طريق تحقير الطفل والتقليل من شأنه، وفي بعض الأحيان يلجأ الوالدان إلى البحث عن أخطاء لطفل ويدون ملاحظات هدامة مما يفقد الطفل ثقته بذاته، وغالبا ما يترتب على هذه المعاملة شخصية انسحابيه منطوية غير واثقة في نفسها، تواجه عدوانها نحو ذاتها ، وهناك الكثير من الآثار السلبية لأسلوب إثارة الألم النفسي فئهي 
كالإحساس بالذنب، والندم، الإثم، والثعور بالدونية والضالة، واحتقار الذات، وتنعكس هذه الآثار على إعاقة النمو النفسي والمعرفي للطقل، وتعطل إثباع حاجته للحب والانتماء

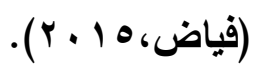

الوجداني.

النظريات المفسرة لأساليب المعاملة الوالدية :

من بين النظريات التي تناولت أساليب المعاملة الوالدية أو عملية التشئئة الاجتماعية

للطقل ما يلي:

- نظرية التحليل النفسي :يرى كل من فرويد وزملائه إن شخصية الفرد تتكون من

ثلاث منظمات: هي الهو والانا والأنا الأعلى. حيث يمثل الهو صور الغرائز ومحتواه اللاشعور ويسعى لتحقيق مبدأ اللذة. وحينما يتصل الهو بالمجتمع المحيط أو البيئة تبدأ عملية تكوين

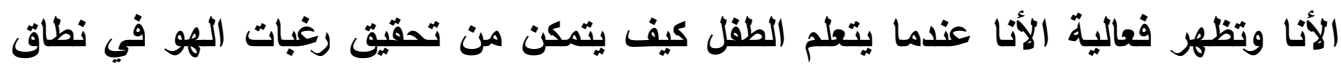
الظروف التي يفرضها المجتمع والبيئة بعاداته وتقاليده. ان الأنا لا يستطيع كبح كل المحفزات الغزيزية لخطرة التي تتنافى مع هذه القيم وتلك التقاليا ويالتالي تأتي أوامر الوالدين والكبار ورقابتهم على تصرفات الطقل وسلوكياته، ويصبح للأب مثلا أوامر ونواه كما له تثجيع ورضي، ومن ثم تثنتق الأنا الأعلى، وميع مرور الوقت مع تعليمات وتوجيهات هؤلاء الكبار

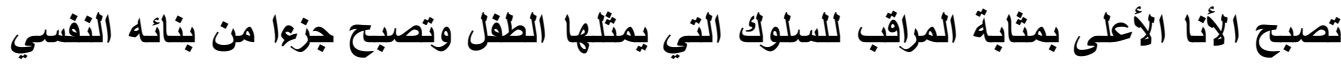

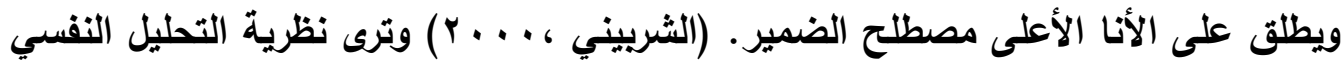
أن التنشئة الاجتماعية قائمة على التفاعل يكتسب فيها الطفل معايير السلوك، وتضفي هذه النظرية على الأم أهمية كبرى في تفاعلها مع طقلها في مواقف التغذية والتدريب على الإخراج، وتعلن عن توحد الطقل خلال مراحل نمو نفس جسمية مع الوالدين ثم يندمج مع الدي خصائص الوالد المتوحد معه وهنا تكتمل تنشئته بنمو الأنا الأعلى. (علي جاد، أكد أصحاب مدرسة التحليل النفسي على أهمية السنوات الأولى في حياة الطقل، كونها أكثر الثرال الفترات مرونة، لأنها يتم فيها تثكيل شخصية الطفل وإكسابه العادات والاتجاهات السوية، كما يشيرون إلى أن الاضطرابات السلوكية التي تظهر في فترة المراهقة، غالبا ما تعود إلى فئل أساليب التربية السلبية التي يتعرضون لها في فترة الطفولة المبكرة، التي تثبت فيها معالم الثخصية في أثناء التشئة الاجتماعية للطقل. (بن راشد، 2014) ويلاحظ أن من إيجابيات 
هذه النظرية أنها أكدت على علاقة الطقل بوالديه ودورهما في عملية التنشئة وفي اكتساب معايير السلوك من خلال لتفاعل معهما.

- نظرية التعلم الاجتماعي :يرى أنصار هذه النظرية أن عملية التشئة الاجتماعية بحد ذاتها عملية تعلم لأنها تتضمن تغيرا أو تعديلا في السلوك نتيجة التعرض لخبرات وممارسات معينة ولأن مؤسسات التشثئة الاجتماعية المختلفة تستخدم أثناء عملية التنشئة بعض الأساليب واللوسائل المعروفة في تحقيق التعلم سواء أكان ذلك بقصد أو بدون قصد. والتطبيع الاجتماعي في رأي نظرية التعلم الاجتماعي هو ذلك الجانب المحدود من التعلم الذي لهاي يعني بالسلوك الاجتماعي عند الفرد، وترى هذه النظرية أن التطور الاجتماعي يحدث عند الأطفال بالطريقة نفسها التي يحدث فيها تعلم المهمات الأخرى وذلك من خلال مشاهدة أفعال الآخرين وتقليدهم ولا شك أن مبادئ التعلم مثل التعزيز والعقاب والإطفاء والتعميم والتتييز التي لها دور في عملية التنشئة الاجتماعية. ويعطي أصحاب هذه هذأ النظرية أمثال "دولار" و "ميلر" أهمية كبيرة للتعزيز في التعلم، والسلوك يدعم أو يتغير تبعا لنمط التعزيز المستخدم

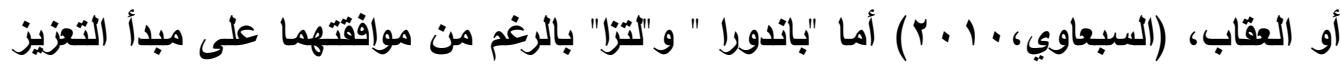

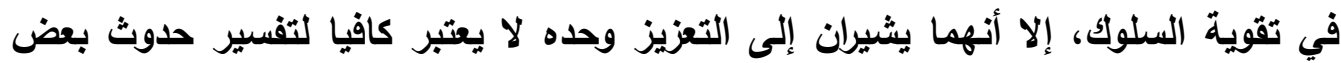

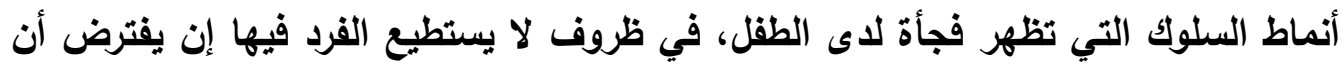
هذه الأنماط قد تكونت تدريجيا عن طريق التعزيز، ويرى" باندورا" أن الناس يطورون فرضياتهم حول أنواع السلوك التي سوف تقودهم للوصول إلى أهدافهم ويعتمد قبول هذه بها

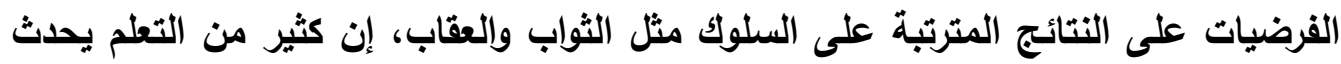

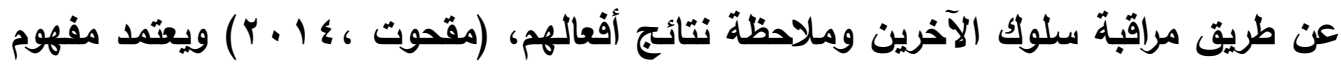
نموذج التعلم بالملاحظة على افتراض مفاده الإنسان، ككائن اجتماعي، يتأثر باتجاهات

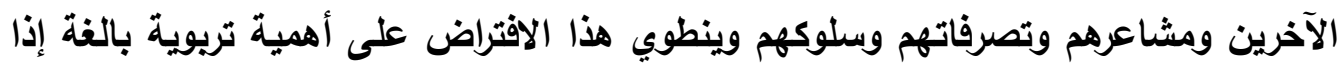

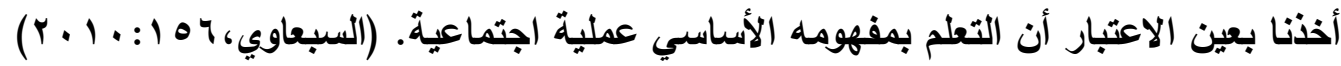
- نظرية البنائية الوظيفية :تفسر النظرية البنائية الوظيفية أن عملية التنشئة الاجتماعية بأنها أحد جوانب النست الاجتماعي. ويذلك تثقاعل مع عناصره للمحافظة على البناء الاجتماعي وتحقيق توازنه .ويتعرض الفرد أثناء التنشئة الاجتماعية لعمليات الضبط الإس والامتثال التي تساعده على التوافق مع مجتمعه، لارتباطها بعلية التعلم، لان الفرد يتعلم 
أنماط ثقافته وقيمها وعاداتها وتقاليدها وأفكارها ورموزها، التي تتنقل من جيل إلى آخر ـ ومن

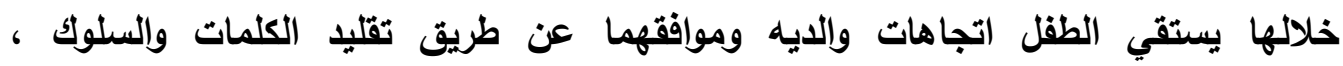

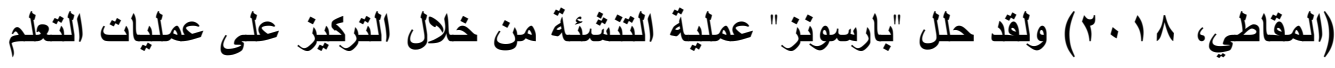

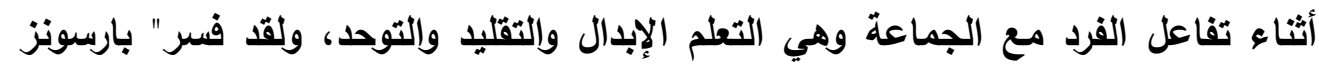

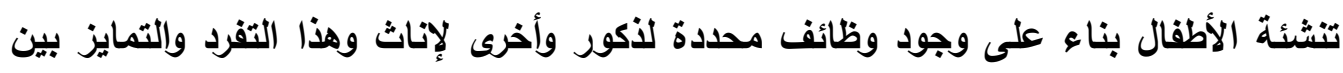
الجنسين يحقق أهداف وفوائد عديدة للأسرة كما يعمل على استمرار النسق الاجتماعي

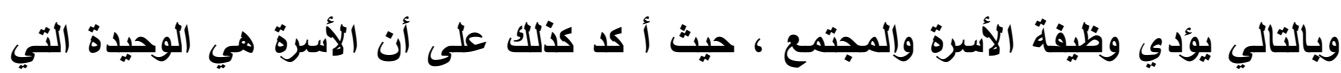

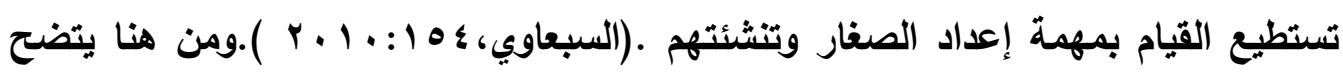

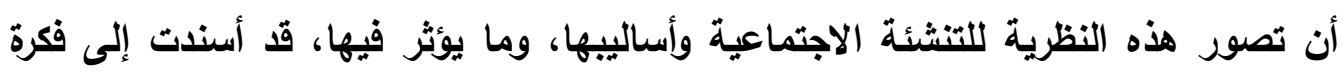

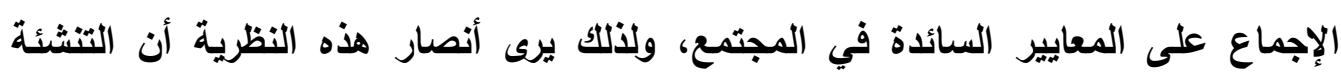

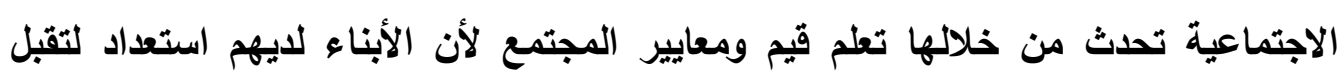

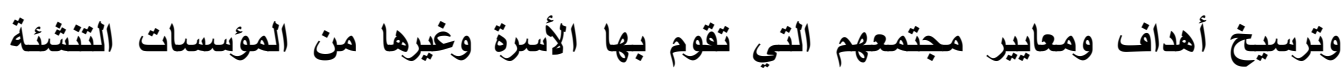

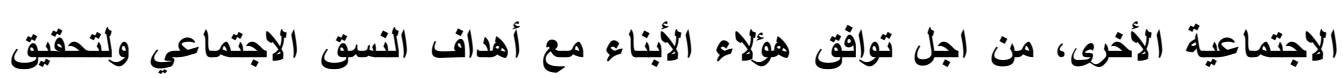

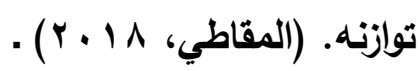
- نظرية الدور الاجتماعي :وتتذذ هذه النظرية مفهومي المكانة الاجتماعية والدور

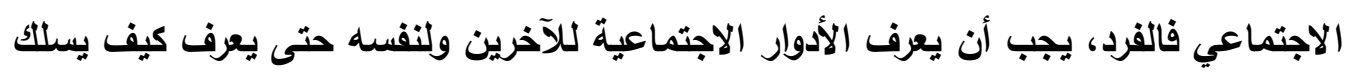

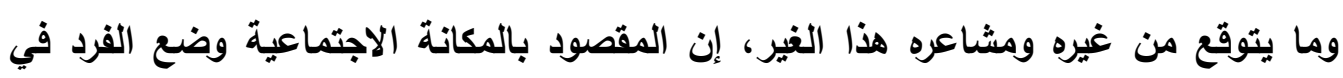

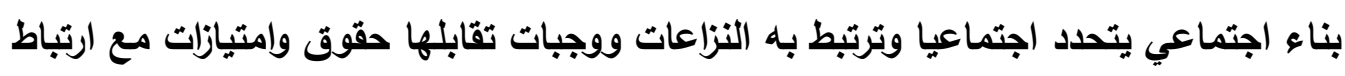

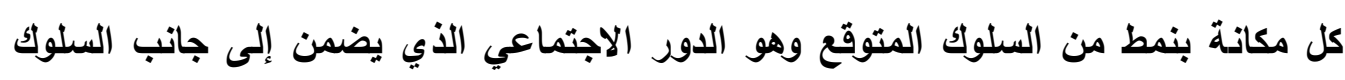

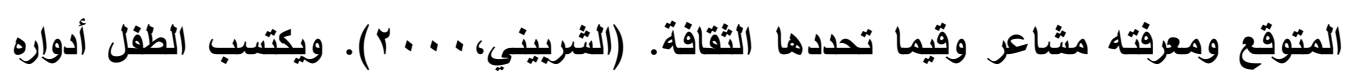

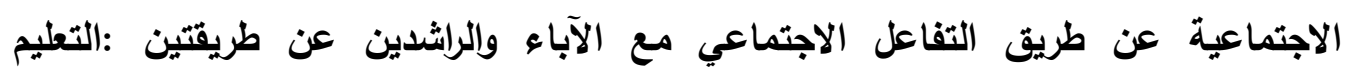

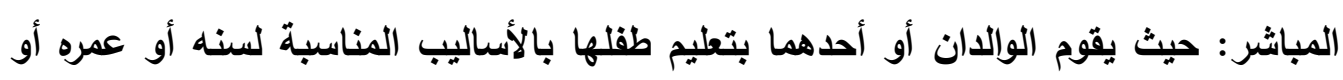

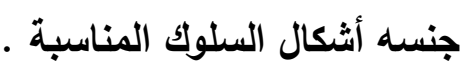
النماذج: يتخذ الطفل من المحيطين به نماذج يحتذى بها وقدوة يقتدي بها. بالإضافة

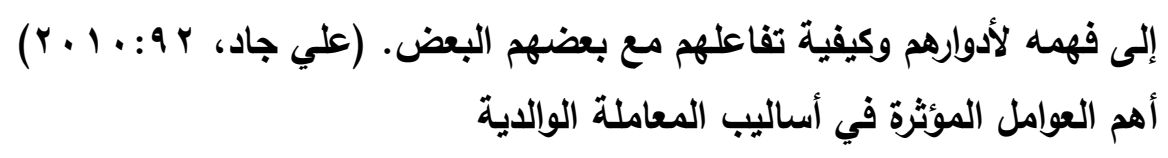


شخصية الوالدين: إن شخصية المضطرية الأب يؤدي دور إيجابيا في رسم المثل السيئ

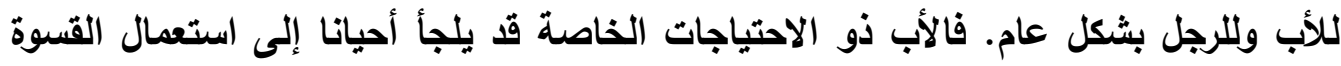
والتهايد كوسيلة لإثبات ذاته وقد يحدث العكس، ويمكن يقال عن الأب يقال الأم، فمثلا الوالدان العصا بيان يفتقران إلى الاستقرار العاطفي في علاقتهما الأسرية، وغالبا ما يتسم أسلوب المعاملة السائدة بالإهمال والتذبذب نتيجة لعدم استقرار وضعهما النفسي والانفعالي.

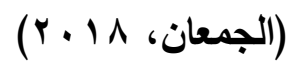

العلاقات بين الوالدين :إن أقوى العوامل المؤثرة لإثبات المعاملة الوالدية انسجام

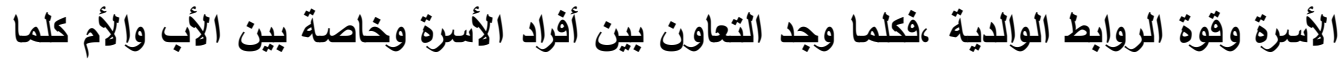
ساعد ذلك على خلق جو منزلي هادئا ينشئ فيه الطفل نثأة متزنة والاتزلان العائلي دوره

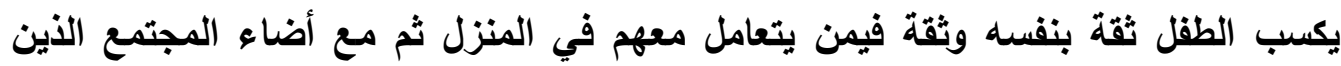

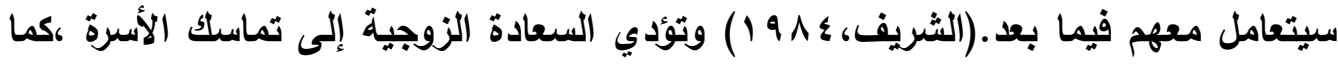
أن الوفاق والعلاقات السوية بين الزوجين يشعر الطقل، بالأمن النفسي في حين تؤدي التئي الذلافات بين الوالدين إلى تفكك الأسرة ، حيث أكلات البحوث الإكلينيكية أن الأسرة التي فئي

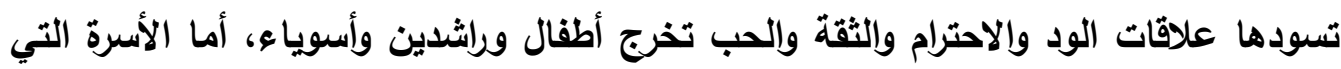

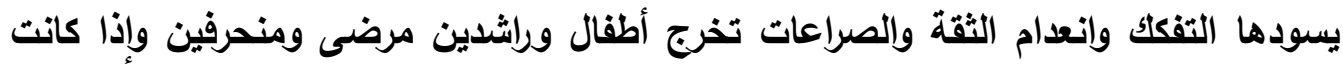

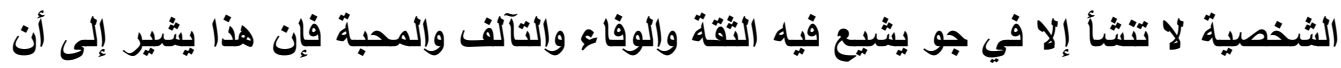
الأسرة تترك أثارها العميقة في حياة الأبناء وتصبغها بصبغتها الهادئة السوية والثناذة

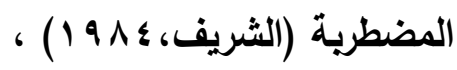
مركز الطقل وتتشئته في الأسرة: يؤثر هذا العامل تأثيرا كبيرا حيث يتذخل في أسلوب

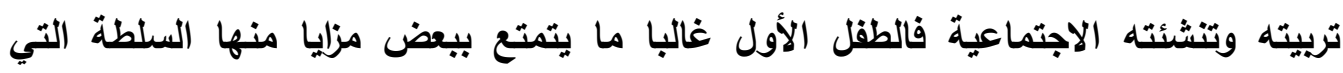
يمنحها الوالاين خاصة حال غيابهما عن المنزل ليمارسها على أخوته الأصغر سنا .والطفل

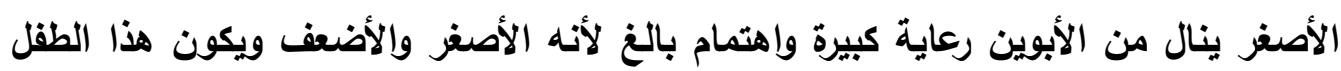

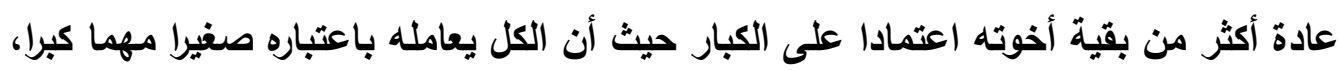

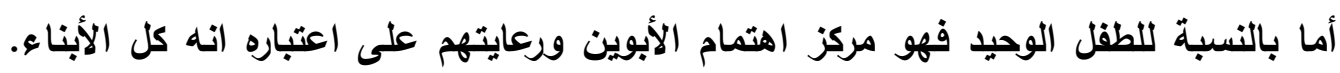

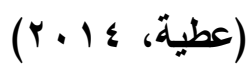


حجم الأسرة :أما بالنسبة لحجم الأسرة (المكونة من الأب والأم والأبناء) إن الشبكة

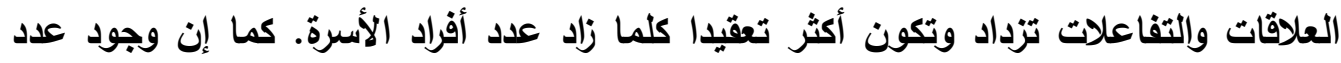
كبير من الأبناء بالإضافة إلى الوالدين يستلزم بالضرورة تطبيق نظام صارم للعلاقات وإلا سادت الفوضى في الأسرة ومن الطبيعي إلا تكون هناك فرصة للتدليل. كما تقل الفرصة أمام الآباء للاحتكاك والتقارب مع كل فرد على حدة ويالعكس، فان فرصة التقاعل بين الإخوة فيما بينهم تزيد، فقد يصبح الأخ أو الأخت الأكبر هم النموذج والقدوة بالنسبة للصغار خاصة إذا لإنا

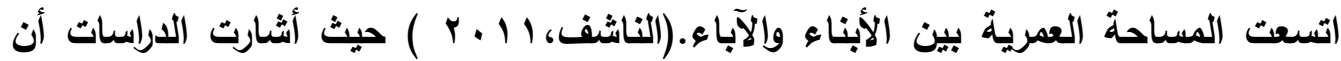
عدد الأبناء في الأسرة يؤثر على أساليب المعاملة الوالدية فكثرة عدد الأبناء تنحو بالآباء إلى أسلوب السيطرة في تحقيق المطالب، أما قلة الأبناء فتنحو بالآباء إلى أسلوب الإفناع والخضوع، وتوصلت أيضا نتائج الدراسات أخرى إن اثر حجم الأسرة في أساليب المعاملة الوالدية للطفل له دلالة جوهرية فعندما يزداد عدد أفراد الأسرة، بسبب كثرة عدد الإخوة تقل فرص التواصل بين الآباء والطقل وتزداد مواقف التفاعل بين الإخوة، ويلجأ الآباء لتبني أساليب تريوية أكثر ميلا للتسلط والقسوة والإهمال وذلك للسيطرة على نظام الأسرة و ضبط الصراع بين الإخوة. بينما تتسم أساليب المعاملة الوالدية في الأسر صغيرة الحجم بالتعاون المتبادل مع الآباء وأطفالهم، بتقديم المساندة العاطفية والحب وخاصة من ناحية الأم والاهتمام بكل أمور الأطفال وخاصة من ناحية التحصيل والنجاح الدراسي، وتتسم بالديمقراطية حيث يسود أسلوب الضبط المعتدل، ونظام العقول وتتوافر الفرص الحسنة لتكوين العادات الانفعالية والاجتماعية. (الرشدان،ه . . ب) ويالرغم من ذلك فان تأثير العدد الكبير

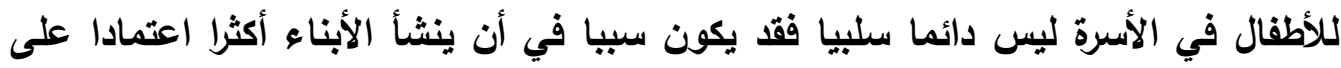
أنفسهم، كما يتعلم الطفل أساليب التعامل مع الأقران والقريبين منه فالعمر مما يفيده في حياته المدرسية والمهنية فيما بعد. وهذا يتضح، عندما نقارن هذا الوضع مع الأسرة التي بها طقل وحيد أو طفلان على أكثر تقدير، حيث يكون هناك تركيز في العلاقات العاطفية بين أفراد الأسرة الواحدة مما يترتب عليه الحماية الزائدة للطقل وتضييق مجال تحركه وتعامله وخبرته. كما يميل الطقل إلى الاعتماد على الآخرين في تصريف أموره اليومية، ويصادف في حياته المستقبلية صعويات في التكيف بسبب ما اعتاد عليه من أن يكون مركز اهتمام الكل، 
المستوى التربوي والتعليمي للوالدين : يعتبر المستوى التعليمي والتريوي للأسرة من أهم

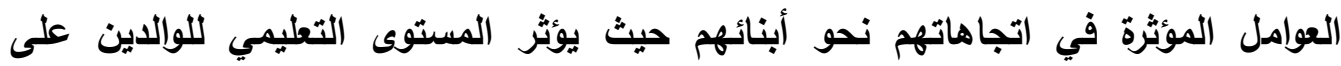
شعورهم بكفاعتهم للقيام بأدوارهم في عملية التشئة الاجتماعية للأبناء وتؤثثر في اتجاهاتهم نحوهم لتكون أكثر هدوء وتقبلا، حيث أظهرت عدة دراسات بأهمية المستوى التعليمي والتريوي للوالدين وأثره على أساليب المعاملة مع الطفل، فإذا كان الوالدان على درجة متكافئة تعليميا أدى ذلك إلى استخدام أساليب السوية في التنشئة المتبعة مثل أسلوب الحرية والديمقراطية في المعاملة واحترام شخصية الطقل في المنزل وتتمية شخصيته ، وتوفير كافة المعلومات التي يريدها الطقل، واستخدام الأسلوب الذي يحقق الأمن النفسي له والذي يقوم على الحب والاستقرار مع مراعاة ثبات نوعية التعامل وعدم الأبذبة التي تؤدي للثك ، أما الوالدين الذين لايهم مستوى تعليمي اقل فإنهم أكثر ميلا للضغط والتسلط على أبنائهم.)

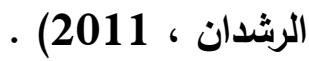

المستوى الاقتصادي والاجتماعي للوالدين :إن مستوى الأسرة الاقتصادي والاجتماعي يؤثز على معاملة الوالدين لأبنائهم وفي العلاقة بين أفراد الأسرة ومدى إثباع الحاجات

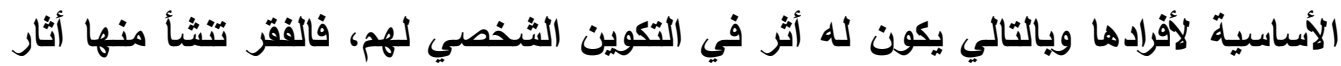
متعددة ومتفاعلة منها سوء التفذية وما يتبعه من أمراض ومنها آثار نفسية ناتجة عن لهن لهن الحرمان وما يخلفه من قلق وإحباط. وفي الحالات الأسر الفقيرة يضطر الأب إلى زيادة

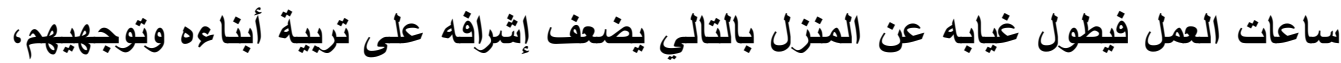
وفي أغلب الأحيان تسكن الأسر الفقيرة في مساكن ضيقة لا تستوفي الشروط الصحية ويفتقر

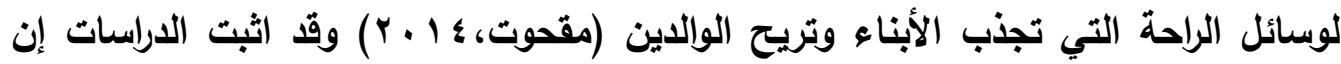
الأسباب الرئيسية للانحرافات الاجتماعية تتبع عن الفقر والحاجة، في حين أوضحت دراسات أخرى إن الوالدين ذات المستوى الاقتصادي الاجتماعي المرتفع يكونان أكثر تسامحا في معاملة أطفالهم حيث يمثل الوضع الاقتصادي محورا هاما في التشئة الاجتماعية للأطفال وتربيتهم، وهكذا نستخلص ان الأسرة تلعب دورا مهما في تنشئة وتربية الطقل حيث يتعلم

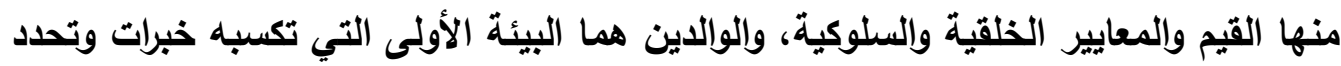
شخصيته ونموه السليم .لذلك يحث العلماء الأسر ويالأخص الوالدين على ضرورة التهائه الاولى التهاج الأساليب الايجابية والسليمة في تربية الأبناء بتقدير كل مجهوداتهم وتنمية استعداداتهم 
وتثجعيهم على الإبداع وتوجهيهم منذ طقولتهم وفهم حاجاتهم ومشكلاتهم ومساعدتهم على منى تجاوزها من خلال الحوار معهم، والابتعاد عن كل الأساليب السلبية التي تكبح مواهبهم وقراتهم وتخفض من مستواهم الدراسي وتؤثر سلبا على نموهم العقلي والتفسي.

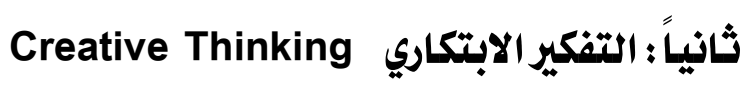
يتفق معظم الباحثين والدارسين في مجال الإبداع والتفكير الإبداعي على أن التفكير الابتكاري يشمل ثلاث مهارات ر رئيسة، وهي: الطلاقة، والمرونة، والأصالة التي شملئها مقياس تورانس للتفكير الإبداعي :Ormrod, Runco \& Albert,1995. 1990).

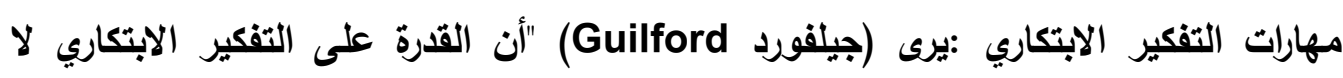

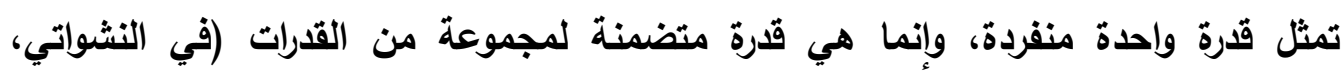

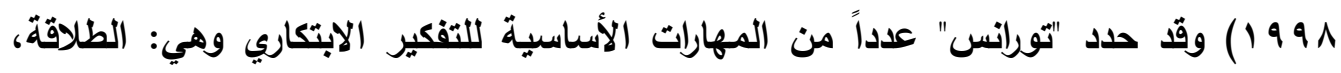
والمرونة، والأصالة، وإلتفاصيل.

\section{Fluency 1}

يعرف "تورانس" (Torrance, I 9 (الطلاقة بأنها القدرة على استدعاء أكبر عدد ممكن من الاستجابات تجاه مشكلة معينة في فترة زمنية محددة .وتعني القدرة على توليد

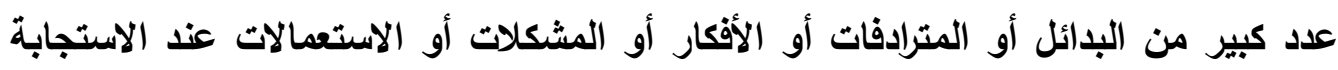

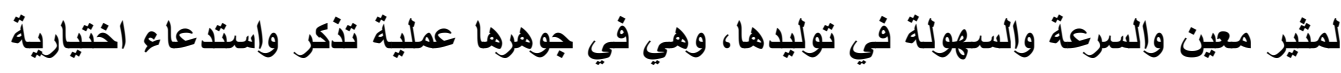

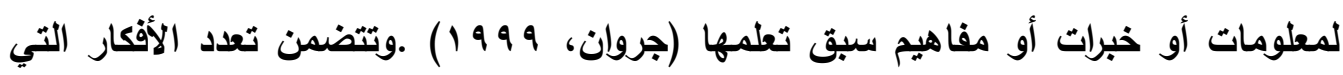
يمكن استدعاؤها أو السرعة التي يتم بها استدعاء استعمالات ومرادفات وفوائد لأثشياء محددة

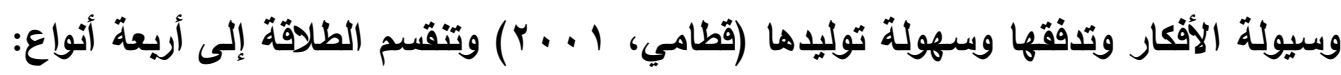

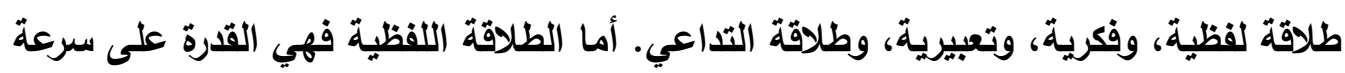
إنتاج أكبر عدد ممكن من الكلمات التي تتوافر فيها شروط معينة. والطلاقة الفكرية هي القدرة على سرعة إنتاج أكبر عدد ممكن من الأفكار التي تنتمي إلى نوع معين من الأفكار في زمن فئن

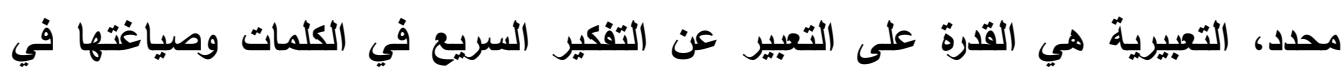
عبارات مفيدة، أما طلاقة التداعي فهي القدرة على إنتاج أكبر عدد ممكن من الوحدات الأولية

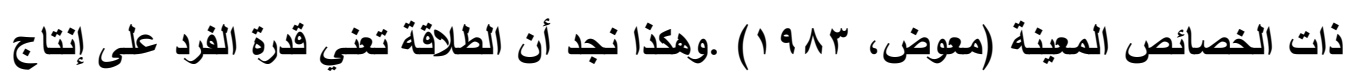

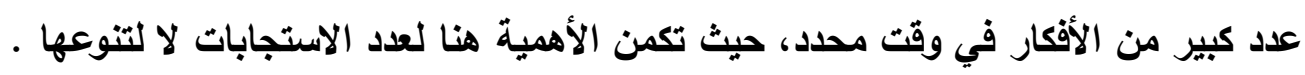




\section{Flexibility المرونة}

ويقصد بها القدرة على تغيير الحالة الذهنية بتغير الموقف، وهي عكس عملية

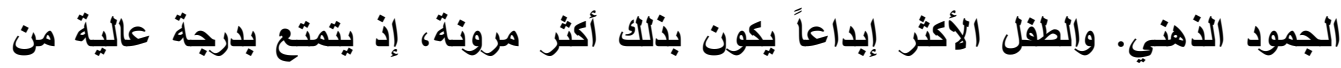
القدرة على تغيير حالته الذهنية، لكي توافق تعقد الموقف الابتكاري. ويتطلب هذا النمط توافر

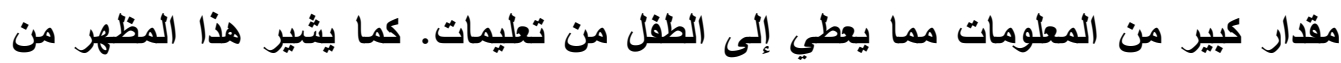
التفكير الابتكاري إلى قدرة الطفل على توليد مجموعة من الاستجابات تبين استعمالات غير الماتير

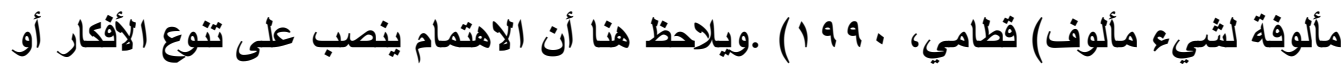

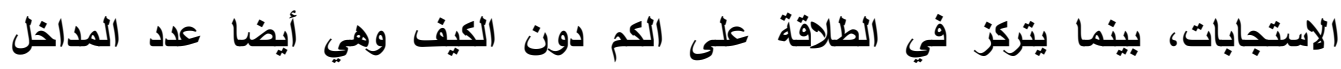

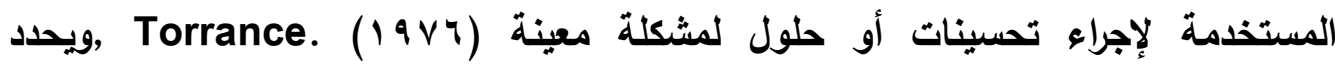

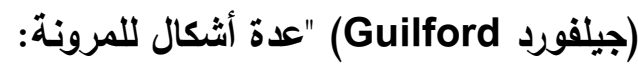

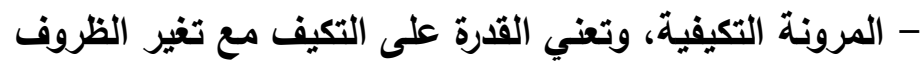

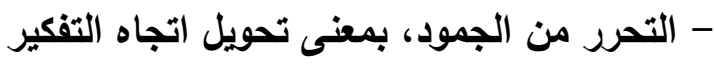
- إعادة تفسير المطلومات، بمعنى مراجعة المعطيات أو بنود المعلومات

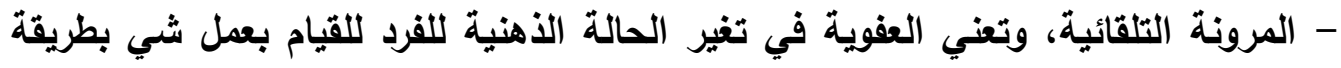
مختلفة (جروان، 999 1 ) أن الإنسان الذي يقف عند فكرة أو يتصلب لطريقة من الطرق هو أقل قدرة على الإبداع من إنسان مرن التفكير قادر على التغير والمرونة التكيفية .فالمرونة

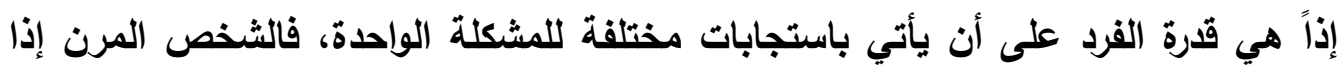

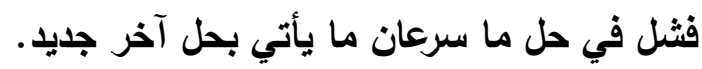

(Originality):الأصالة

وهي القدرة على سرعة إنتاج أفكار تستوفي شروطاً معينة في موقف معين كالجدة

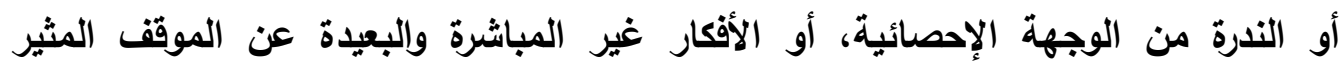

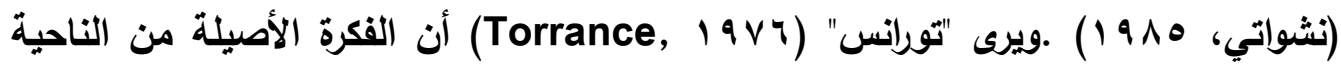

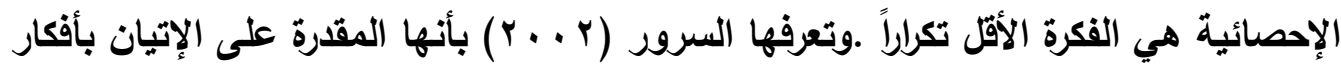

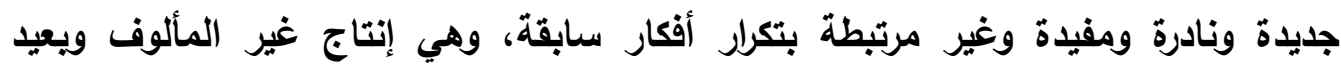

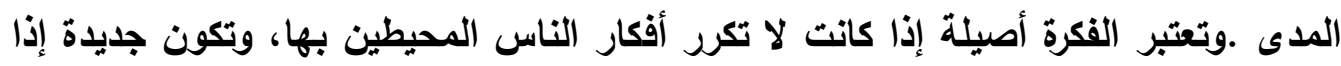

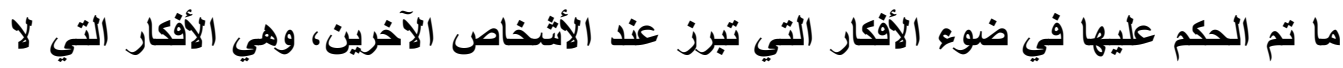


تخضع للأفكار الثائعة، وتتصف بالتميز والثخص صاحب التفكير الأصيل هو الذي يمل من

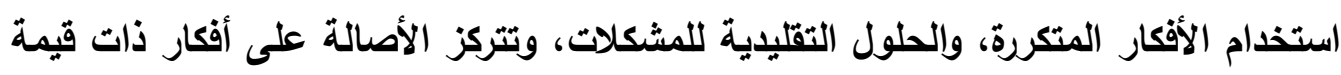

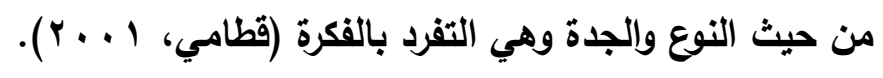

(Elaboration) التفاصيل)

ويعرفها "تورانس" (Torrance I 9 V بأنها الزيادة أو البناء على الفكرة الرئيسية لتصبح أكثر جاذبية. وهي الوصول إلى افتراضات تكميلية تؤدي بدورها إلى زيادة جديدة، وهي عبارة عن مساحة الخبرة والوصول إلى تنمويات جديدة مما يوجد لدى المتعلم (قطامي،

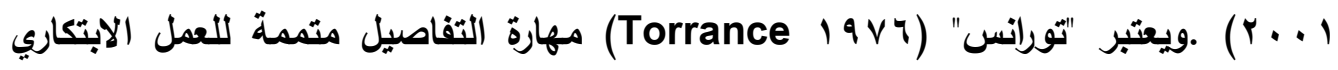
وتحتاج إلى جه وتركيز طويل، وقد يفشل أصيلو التفكير في إتمام عملهم لعدم قدرتهم على

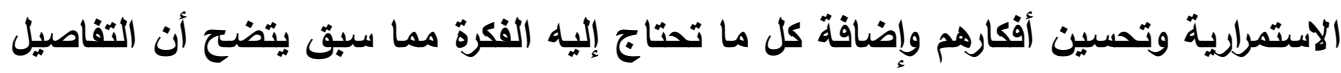

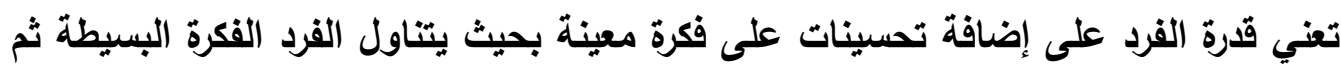
يقوم بإضافة أفكار اخري . -التفكير الابتكاري في ضوء النظريات :تعددت النظريات التي تفسر التفكير الابتكاري، وستعرض الباحثة لبعض هذه النظريات مثل: نظرية التحليل النفسي، والنظرية السلوكية، والجشطلت، والنظرية المعرفية . - نظرية التحليل النفسي :يفسر أصحاب هذه النظرية الابتكار من خلال آراء "فرويد" في أنه لا يختلف في أساسه وديناميكياته عن الاضطراب النفسي والذي يبدأ لاى الفرد من أيام حياته الأولى (يس، I . . P ). فالابتكار من وجهة نظر "فرويد" ما هو إلا تعبير عن حيلة دفاعية تسمى بالإعلاء، وعن طريق هذه الحيلة الدفاعية يعبر الفرد عن طاقاته الجنسية

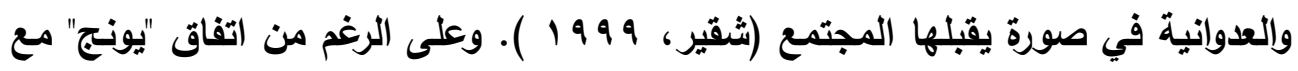
"فرويد"، فإنه يختلف معه في تحديد اللاشعور، ففي حين يرى "فرويد" أن معظم اللاشعور مكتسب وشخصي، نرى "يونج" يميز بين نوعين من اللاشعور إحداهما شخصي وهو ما

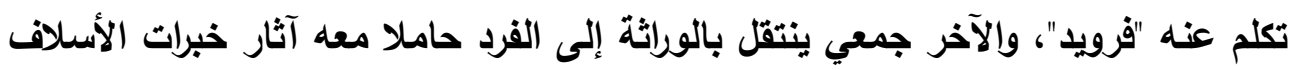
وتراثهم، وهذا اللاشعور الجمعي عند يونج هو مصدر الإبداع (Katya, 1998).وقد فرق "فرويد" بين الابتكار والاضطراب النفسي، حينما أوضح أن الاضطراب النفسي ينشأ

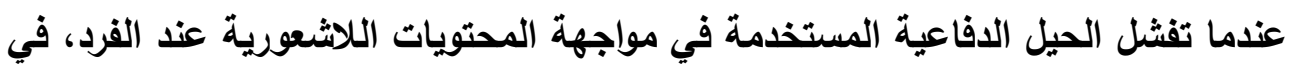


حين أن الابتكار يحدث نتيجة لنجاح الإعلاء، وهي الحيلة الافاعية المستخدمة في التعبير

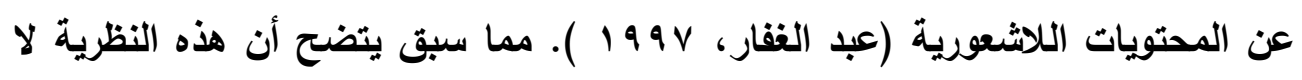
تختلف في تفسيرها للتفكير الابتكاري عن تفسيرها للشخصية، فهي ترى بأن التفكير

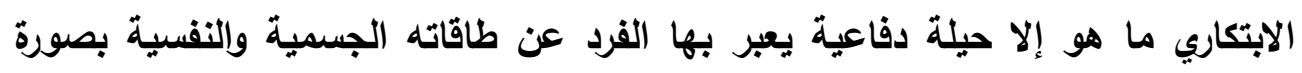

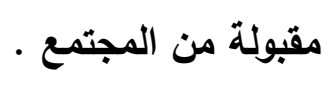

-النظرية السلوكية :قدم "ميدنك Mednick "تصوراً نظرياً للعملية الابتكارية، وهو تصور يقوم على الاقتران الزمني بين المثير والاستجابة، ويرى أنه كلما كانت العلاقة أو الارتباط

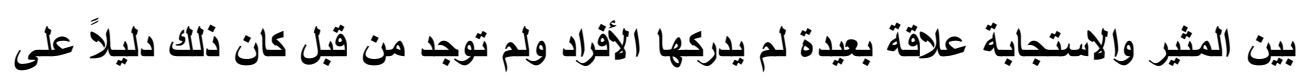

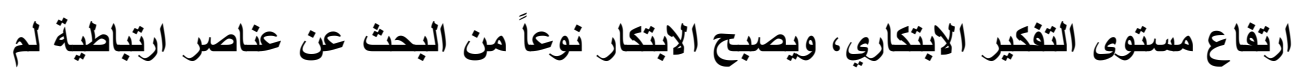

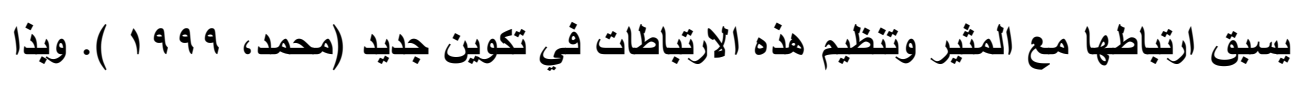

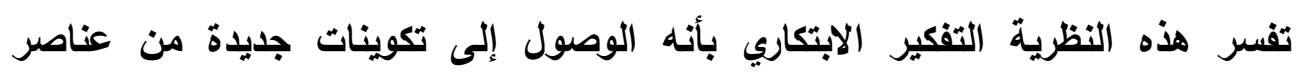
ارتباطيه تتوافر فيها شروط معينة وأن تكون ذات فائدة، كما ويرى أصحاب هذه النظرية

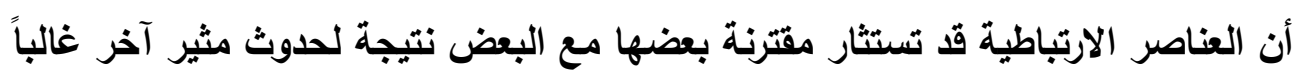

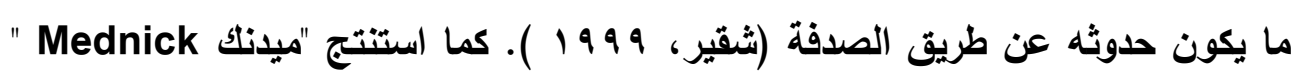
أنه كلما كان عدد الترابطات التي لاى الفرد للعناصر الأساسية للمشكلة أكبر، فإن إمكانية

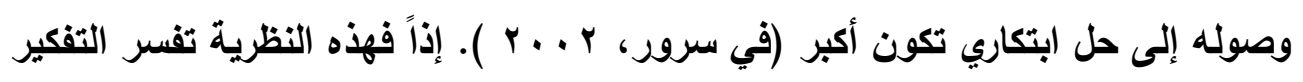

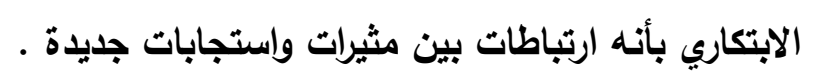
-الجشطلت :يرى أصحاب هذه النظرية أن معرفة حلول أي مشكلة إنما يكون بالنظر إلى مئى

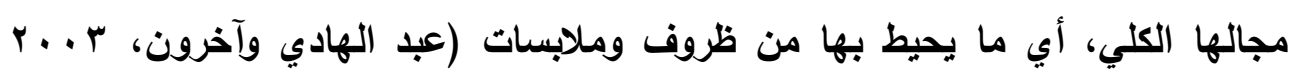
.ويرون أن الابتكار هو الذي ينزع إلى القيام بعمليات تنظيم وإعادة تنظيم المجال

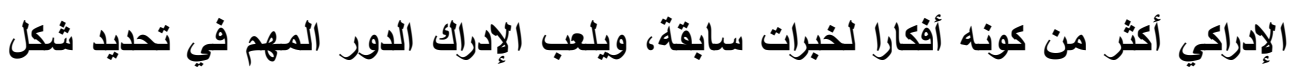

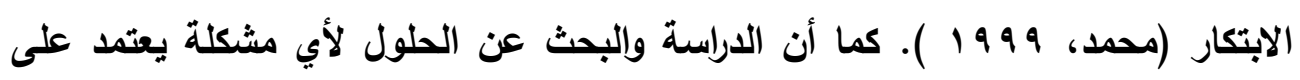

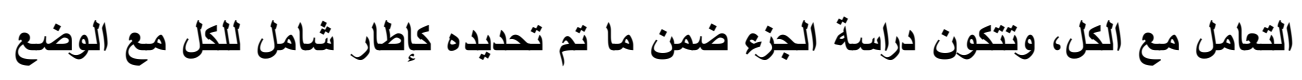
في الاعتبار أن الحلول الابتكارية ليست نتاج عملية مرتبة ومسلسلة لكنها تظهر بصورة فجائية أثناء محاولة إعادة ترتيب عناصرها وفحصها في إطارها الكلي، ولا نستطيع توقع الإن هذه اللحظة، ولا يمكن بالطبع التسليم بصورة كاملة بفكر الحس أو الفجائية في ظهور 
الأفكار الابتكارية، حيث إنها تثكل أحد العناصر وليست كلها، ولا تنكر الحاجة إلى التفكير والبحث بشكل حاد (محمد، 999 (19 ) ). وهكذا نرى أن هذه النظرية تفسر الابتكار

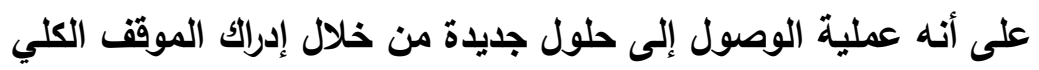

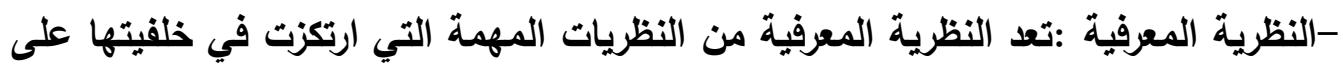
الجوانب العقلية، وأفضل ما طرحته النظرية المعرفية ما جاء به "بياجيه"، حيث يرى بأن هناك عمليات متذاخلة تشكل الفهم والاستيعاب ممثلة في عملية التمثيل والمواعمة التي تثكل عملية التكيف، ويالتالي تؤدي تثكيل التوازن المعرفي العام لدى الكائن البشري (عبد

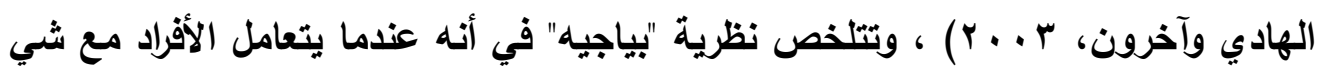
جديد أو غريب عن بنائهم المعرفي يحدث اختلال في التوازن، وتتطلب عملية إعادة التوازن استيعاب الفرد هذا الثيء الجديد، فيقوم بتعديل البناء المعرفي الخاص به للتعامل مع

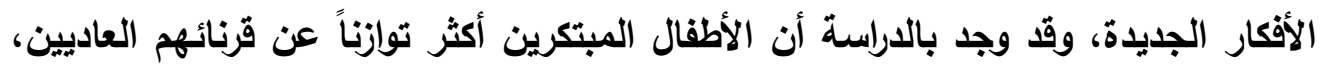

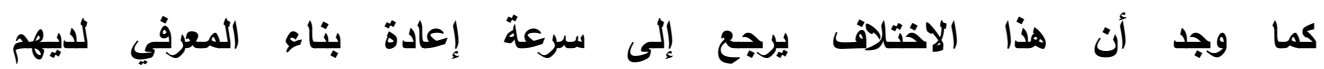

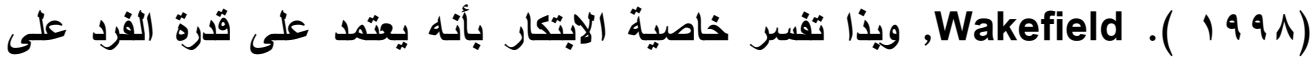
سرعة إعادة البناء المعرفي لتحقيق التكيف .يتضح من العرض السابق للنظريات المفسرة

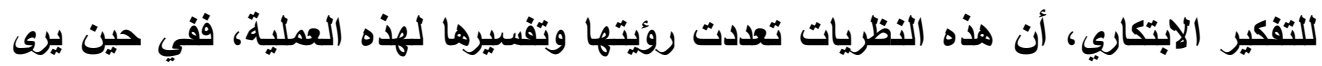
"فرويد" أن التفكير الابتكاري حيلة دفاعية تكثف عن الصراعات الداخلية بأسلوب يقبله المجتمع، نرى السلوكيين يفسرون التفكير الابتكاري على أنه ارتباطات بين المثيرات

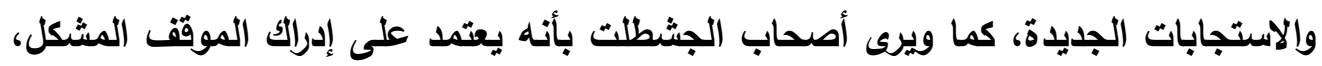

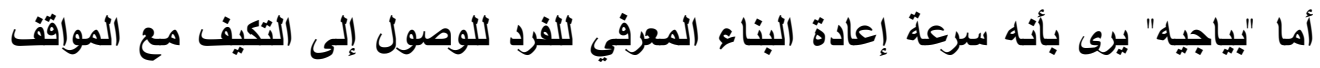
الجديدة. ونلاحظ أن هذه النظريات في مجملها تلفت النظر إلى الإنتاج وإن اختلفت

تفسيراتها له.

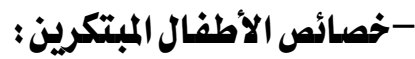

تعتبر معرفة خصائص الطقل المبدع ذات فائدة للمربي/ للمعلم من أجل تحديد الأطفال المبدعين واكتثافهم، وتنمية قراتهم الإبداعية، والحيلولة دون إعاقتها، وكما يقول "تورانس": "لا يميل المعلمون إلى التعامل مع الطقل المباع"، ومرد ذلك إلى ما يتصف به به الإسه الطقل من خصائص غير عادية، تتطلب تخطيطاً وأنشطة خاصة، لا بـ من مراعاتها، الأمر 
الذي يعني بذل جه خاص، وإلا فإن هذا الطقل سينقلب إلى طقل مشاكس، يهذف إلى إثغال

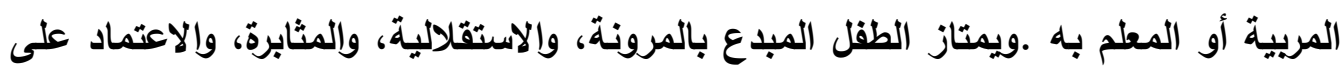

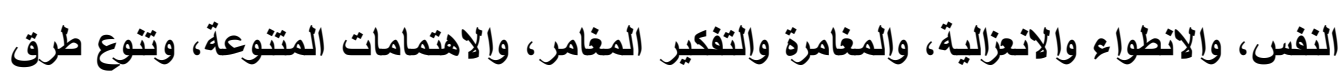

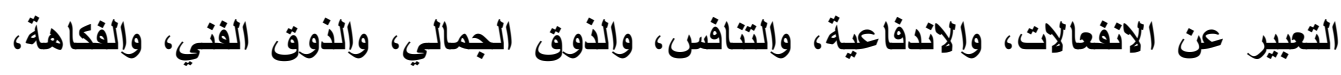

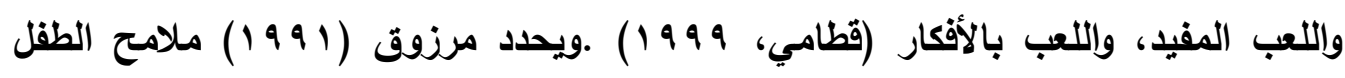
المبتكر بأنه الطفل الذي تظهر لايه استعدادات الإنشاء والتركيب بطريقة واضحة، ولاض، ويأتي بحلول جديدة وأفكار أصيلة لما يعرض عليه من مشكلات، حتى ولو كانت تلك الحلول غير لائه

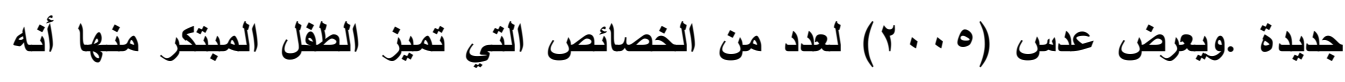
يتفوق على أقرانه في القدرة على الحديث، كما أنه يسعى لمزيل من المعرفة، ويحب الكتابة،

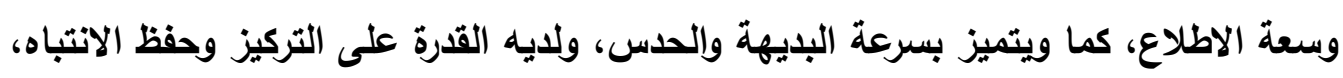

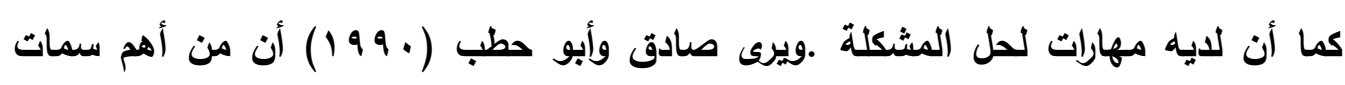

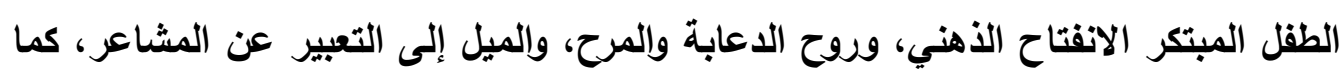

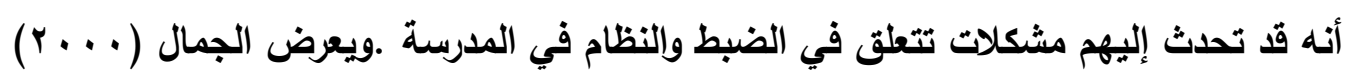

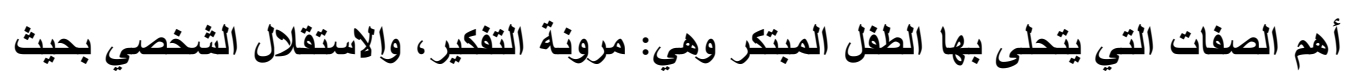

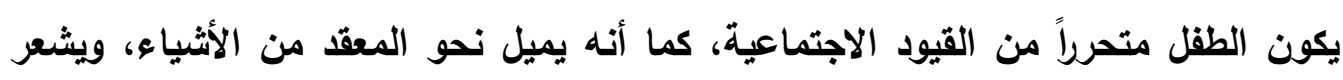

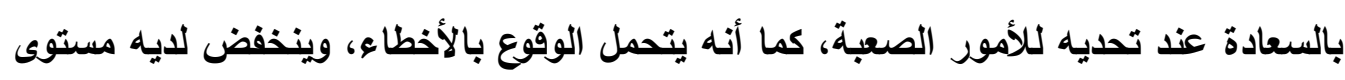

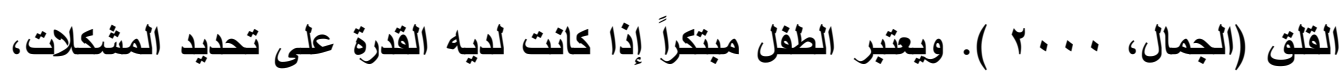
واقتراح الأفكار الكثيرة لحلها فلا بد أن يكون لديه بعض المعارف التي يبحثها بطرق ووسائل

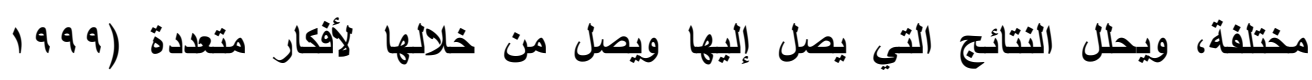

(Isenberg,

التفكير الابتكاري لاى الأطفال الموهويين ذوي صعويات التعلم: أكدت الاتجاهات المعاصرة في تربية أطفال ما قبل المدرسة على أهمية تعريض الطقل للمثيرات الحسية

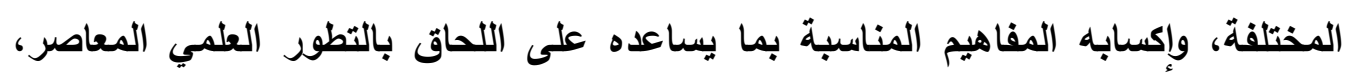
حتى لا نهار الكثير من طاقاته وقدراته العقلية، وحتى لا نفقده العديد من الخبرات. فالطقل

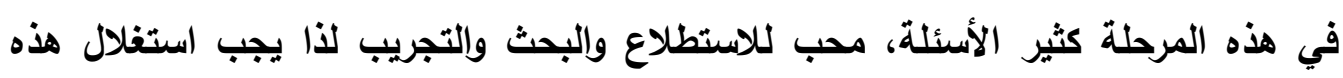

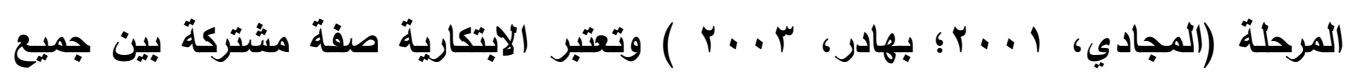


الأطفال، ولا ينقصه سوى المناخ الصالح الذي يظهر هذه القدرات وينميها، كما أن الابتكار

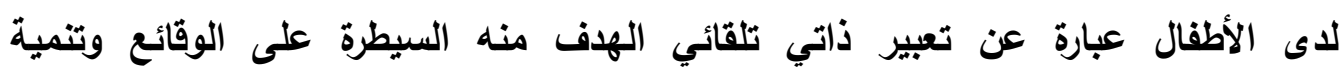

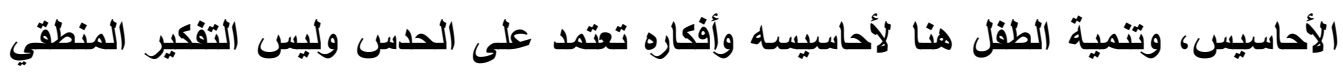

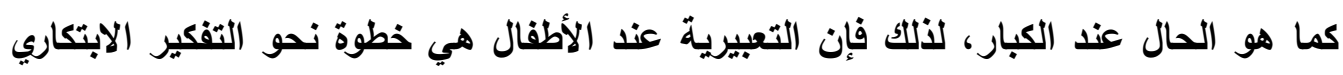

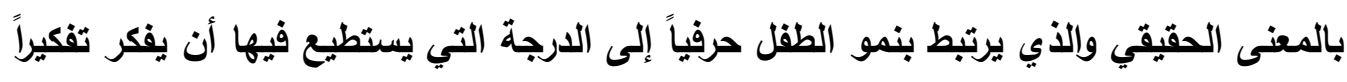

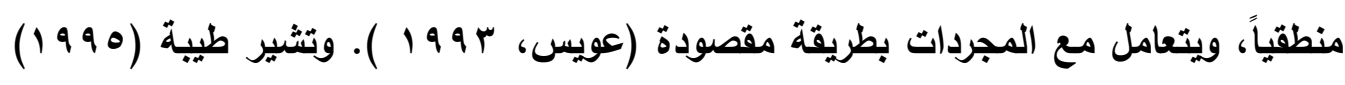

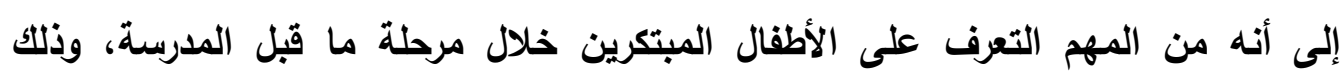

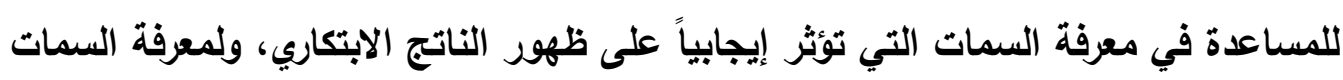

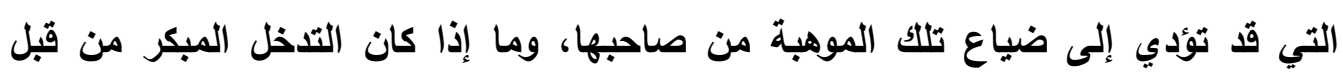

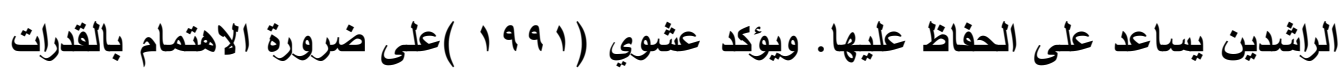

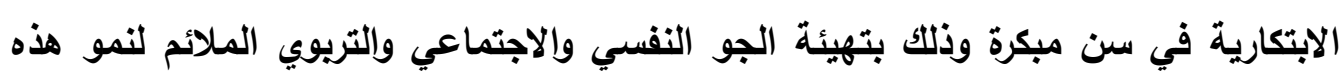

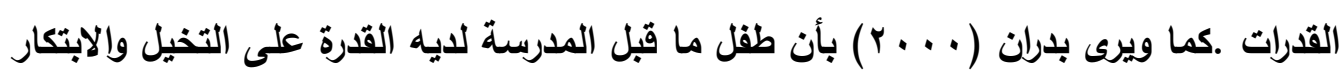

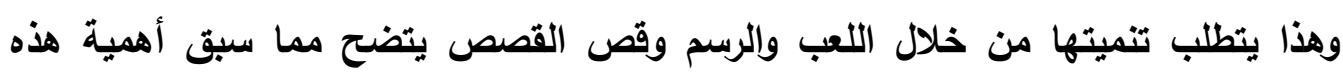

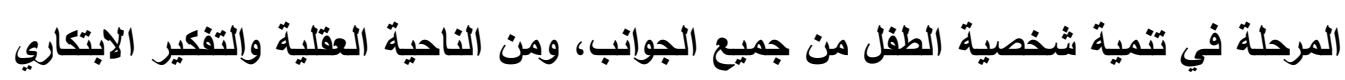

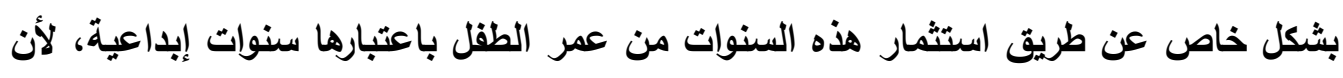
ما يتم تعلمه فيها يدوم تأثيره مدى الحياة.

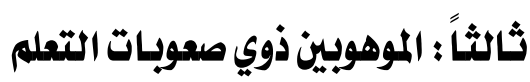

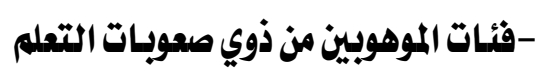

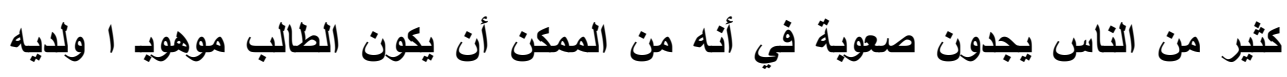

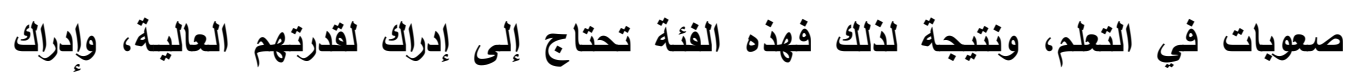

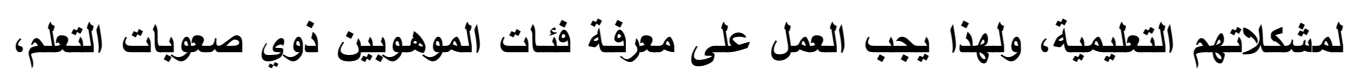
لتسهيل عملية التعرف عليهم لمساعدتهم في الحصول على الجنى الخدمات المناسبة التي

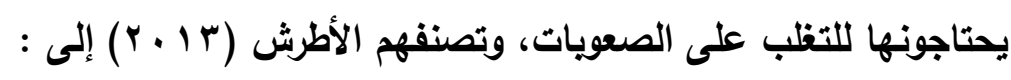

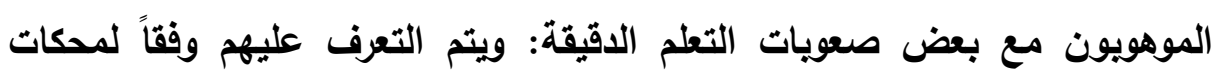
الموهبة بسبب ارتفاع مستوى ذكائهم أو إبداعاتهم أو تحصيلهم الأكاديمي، إلا أنه مع تنزايد

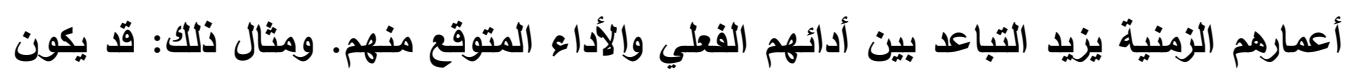


أداء بعض الطلبة مرتفعاً في القدرات اللغويـة والتعبيرية، ولكنهم قد يعانون من صعويات في الكتابة أو التهجئة، وغالباً ما يلفت هؤلاء الطلبة نظر معلميهم بقدراتهم اللفظية المرتفعة، إلا أن قرتهم على التهجئة والقراءة والكتابة ورداءة خطهم تغاير ذلك تماماً . ثنائيو غير العادية المقتعة (أو المطموسة): وهم الذين يجمعون في آن واحد بين مظاهر الموهبة وصعويات التعلم، ومثال ذلك مظاهر الموهبة (الاستدلال، إدرالك العلاقة، والتفكير، والبراءة في الحديث)، تطمس مظاهر الصعويات التي يعانونها، والعكس صحيح إذا أنه قد تطمس الصعويات مظاهر الموهبة وغالباً ما ينتظم هؤلاء الطلبة في فصول عادية . ذوو صعويات التعلم الموهويون: يتم التعرف عليهم كذوي صعويات تعلم أكثر من كونهم موهوبين نظراً لتدني أدائهم في مختلف المواد وفشلهم الدراسي، إذ يركز المعلمون والأسرة على ما لايهم من صعويات، ويصرف النظر عما يمتلكون من استعدادات غير عادية، بل يتم تجاهلها وإهمالها، ويالتالي تكون النتيجة تأثثرات سلبية على أدائهم الأكاديمي وتولد شعور بضعف المقدرة والكفاءة الذاتية .ويرى الباحث أنه يمكن تحديد الطلبة الموهويين من ذوي صعويات التعلم، على أنهم موهويون يظهرون في نفس الوقت صعويات في التعلم. ولا يتم عادة ملاحظة صعويات التعلم التي يعاني منها هؤلاء الطلبة على مدار حياتهم التعليمية تقريباً. وعندما تزداد تحديات المدرسة تزداد الصعويات الأكاديمية التي يوجهونها،

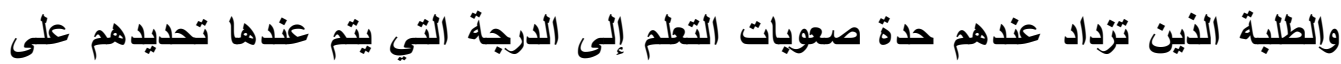
أنهم يعانون من صعويات التعلم، لكن لم يسبق أبداً التعرف على قدراتهم الاستثنائية أو إهم توجيهها وهي كبيرة جداً، والطلبة الذين تعجب قدراتهم ومواطن عجزهم بعضها بعضاً، هؤلاء الطلبة يجلسون في حجرات الدراسة العامة، يحرمون من الخدمات التي تقدم للطلبة الموهويين الذين يعانون من صعويات التعلم. كما أن هذه الفئات من الممكن أن ي ظهروا قدره عالية في القيادة أو الفنون لكن ليس في المجالات الأكاديمية - تشخيص الموهوبين من ذوي صعوبـات التعله :

إن الأفراد ذوي صعويات التعلم يواجهون صعويات في بعض المجالات المتعلقة بتنمية المهارات، للحصول على أداء جيدا أو متفوق بالمواد الدراسية مقارنة مع الطلبة الآخرين. حيث إن وجود صعوية في التعلم لا يكون نتيجة القدرة الفكريـة المحدودة، وإنما يمكن أن تكون بسبب البيئة الاجتماعية والحالة العاطقية أو البيئة المادية والطبية التي تثكل عقبات 
تمنع الموهويين من الحصول على تحصيل أكاديمي مرتفع. فقد يكون الطالب موهوب بشكل استثنائي في مجال معين مثل الرياضيات، والقراءة، وموسيقى الآلات أو الفن، ولكن يظهر ئهر ضعفاً كبيراً وغير متوقع في مجالات أخرى من مجالات التعلم ، ويعد تثخيص الموهويين ذوي صعويات التعلم من أولى خطوات الكشف عن من الموهبة، ومن ثم تحديد استراتيجيات رعايتهم، وفي هذا الإطار لابد من تعيين المحكات التي يتم الإسناد إليها في عملية التشخيص، في هذا الإطار هناك أريعة محكات يتم في ضوئها التعرف على أولئك الطلبة الموهوبين ذوي صعويات التعلم وتحديدهم، وهي (عبد المعطي، وعبدالحميد، 9 . . ب ) ):

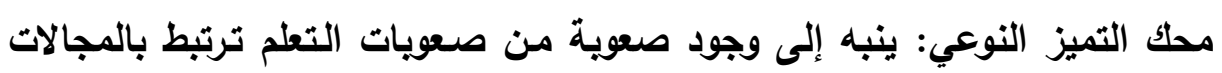
الأكاديمية أو الأدائية .محك التفاوت: ينبه إلى وجود قر من التباين بين معدلات الذكاء أو أو

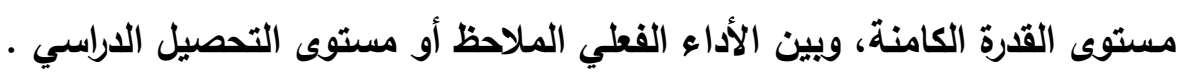
محك الاستبعاد: ينبه إلى إمكانية تمييز الموهويين ذوي صعويات التعلم عن ذوي الاعي

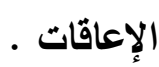

محك التباين: توجد بعض اللـلالات التي تُميز أداء الموهوبين ذوي صعويات

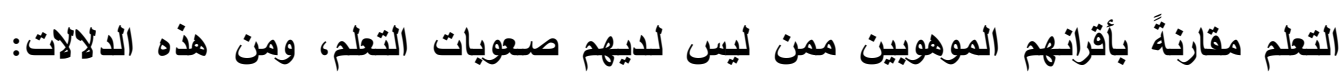

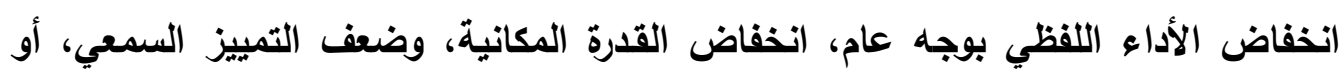
تمييز أصوات الكلمات والحروف، وغيرها .أساليب التعرف على الموهويين ذوي صعويات التهات التعلم :للتعرف على الموهويين ذوي صعويات التعلم وتثخيصهم يجب الأخذ في الاعتبار مجموعة من العمليات المتعلقة بجوانب القوة والضعف لايهم، ويلخل في ذلك ما يلي (عبد

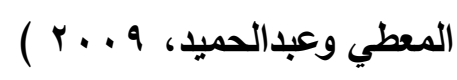

\section{خصائص الموهوبين ذوي صعوبات التعله :}

يمكن للطلبة الموهويين ذوي صعويات التعلم تعويض هذه الصعويات أو التظلب

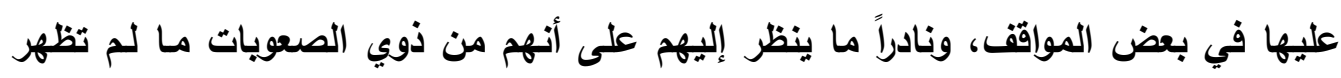

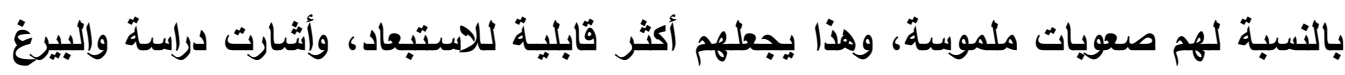
Walberg ( ( $9 \wedge \wedge$ ) التركيز، ومثابرون، ولديهم قدرات عالية في التواصل اللفظي، ويتمتعون بنسبة ذكاء مرتفعة نسبياً، وأصحاب قيم عالية، ولديهم حساسية مفرطة ومتفائلون، ويتمتعون بالجاذبية ، كما ولئه 
أثارت دراسته إلى أن الموهوبين لايهم خصائص مشتركة من أ همها (ميول إلى القراءة أكثر

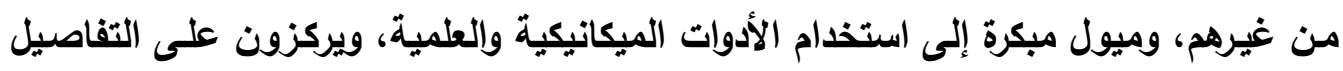
الاقيقة، ومثابري ن وذوي نفس طويل في العمل، وينجزون مهامهم الدراسية بسرعة فائقة، لايهم ميول إلى الخيال وحب الاستطلاع، ورغبة دائمة في التعبير عن أ فكارهم بطريقة

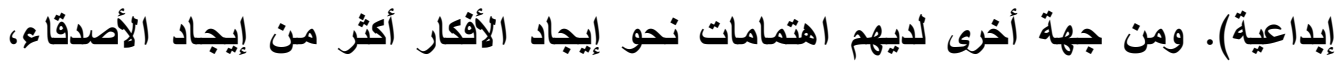

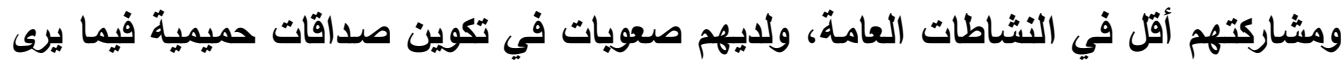
مينير (.99 (19.) Minner أن الكثير من الموهوبين ذوي صعويات التعلم يفشلون في إتمام المتطلبات الملائمة للتقويم المدرسي كما ينثده المطلمون، بسبب اتجاه المطلمين إلى الميل

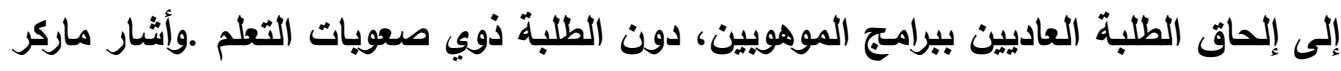
وروجر ونيلسون ويايرلي Nielson, Rogers, Marker 1996,\& Bauerle) إلى أن الطلبة الموهوبين ذوي صعويات التعلم يحتاجون إلى معرفة جوانب القوة في نواحي ذكائهم، بما في ذلك جوانب القوة الإبداعية الحسية مثل التخيل والحلول والاقتراحات غير المألوفة، ويسبب الصعوية التي تواجههم في التعامل ميع الرموز المجردة في الترتيب من خلل الذاكرة

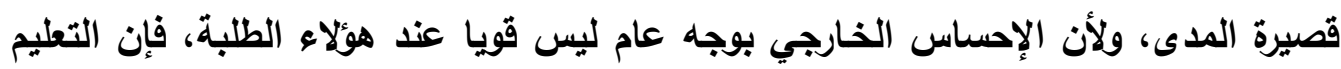

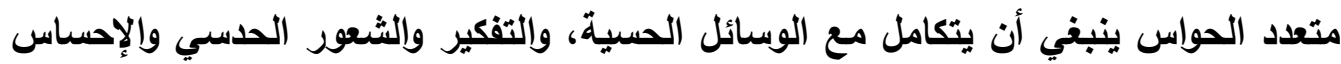

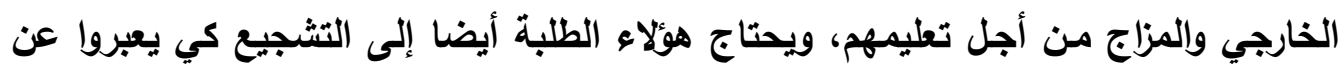

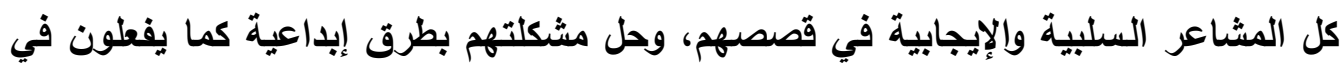

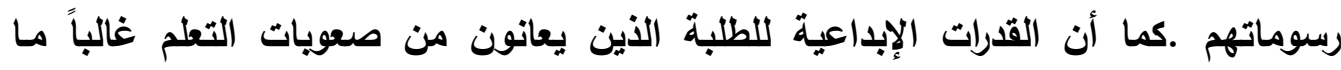

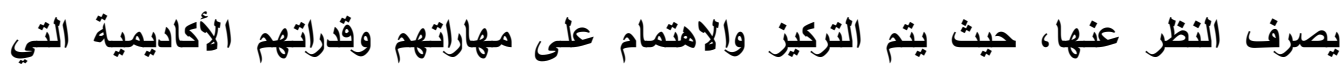
يظهرون من خلالها النجاح ولو الجزئي، إن استراتيجيات حل المشكلات الإبداعي تهلف إلى التى مساعدة الطلبة على إيجاد الحلول بأنفسهم عن طريق القراءة العلمية وتوجيه الأسئلة،

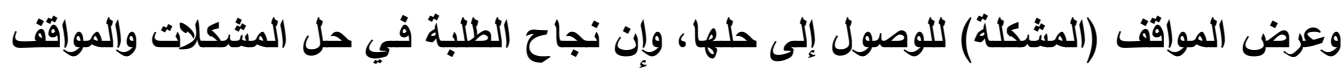

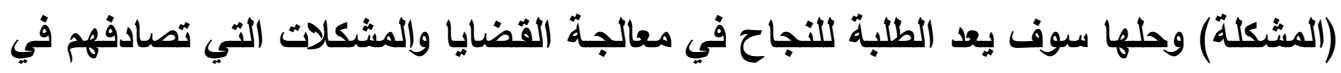

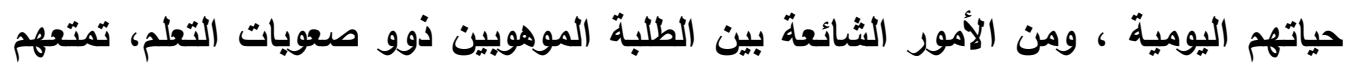

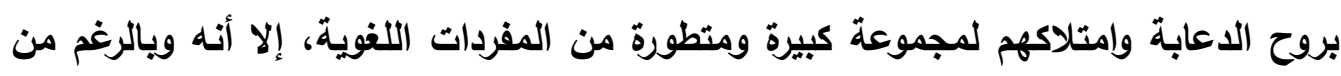
ذلك يعاني البعض منهم من انذفاض القدرة على فهم الدعابة وتفسير الرموز الاجتماعية، 
مما يؤثر سلباً على تفاعلاتهم الشخصية، كما قد يمتلكون مجموعة واسعة من الاهتمامات في مجالات دقيقة، إلا أن تركيزهم ودافعيتهم قد يتشتت بسهولة في المهمات الأكاديمية البسيطة، ومن الصفات ا لملاحظة عند الطلبة الموهويين ذوي صعويات التعلم عد م القدرة على الموازنة بين اهتماماتهم وقدراتهم، ولسوء الحظ يستخدم المعلمون هذا التباين كإشارة إلى أن الطلبة غير موهويين، ويركزون على نقاط الضعف، وعلى تثخيص الصعويات التعلمية لديهم وإهمال نقاط القوة عندهم، مما يؤدي إلى إحالتهم إلى برامج التربية الخاصة ونئ

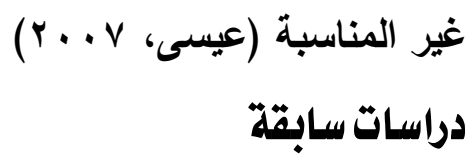

هناك العديد من البحوث والدراسات التي تناولت أساليب المعاملة الوالدية للأطفال الموهويين في المنطقة العربية، وقد قدمت نتائج مختلفة أثرت النقاش والمعرفة حول هذا الموضوع، ومن تلك الدراسات نجد دراسة الحربي (990) والتي تناولت التنشئة الأسرية

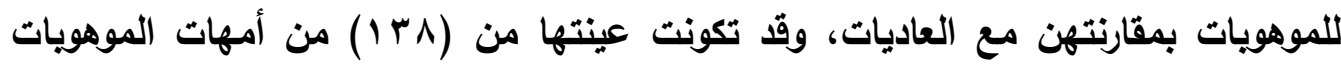

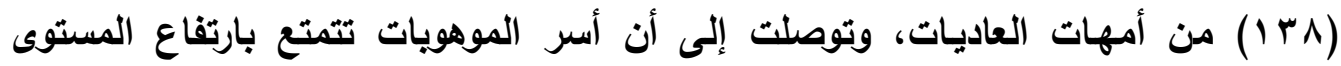

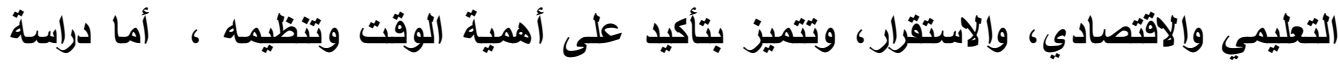

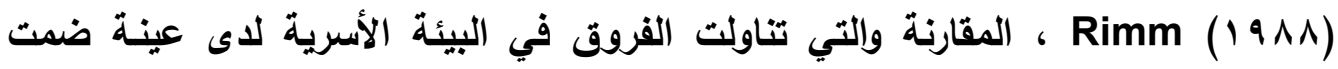
(Yr) من الموهوبين ضعيفي الانجازات في مقابل مجموعة من الموهوبين من مرتفعي

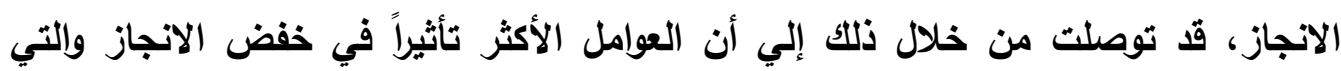

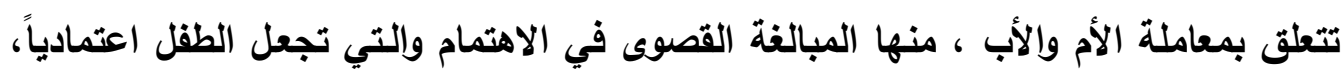

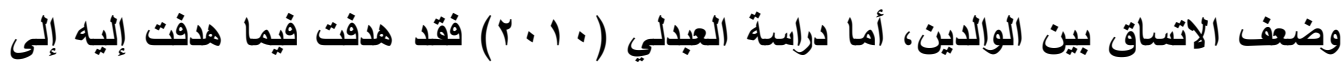
التعرف على مستوى وعي الأسرة بدورها في رعاية الطفل الموهوب وتأثير بعض المتغيرات عليه، وقد طبقّت فيها على عينة قصدية من أسر الموهوبين بمدينة مكة المكرمة بلغ عددها

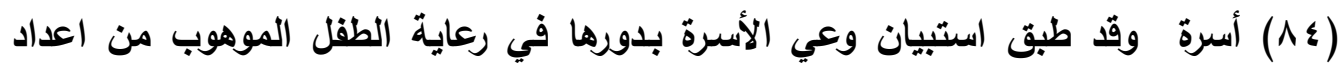
الباحث، وقد توصلت من خلال ذلك إلى أنه يوجد فروق في مستوى وعي الأسرة بدورها في رعايةة الطفل الموهوب تبعاً لكلٍ من (عمل الأمهات لصالح الأمهات العاملات، ومستوى تعليم

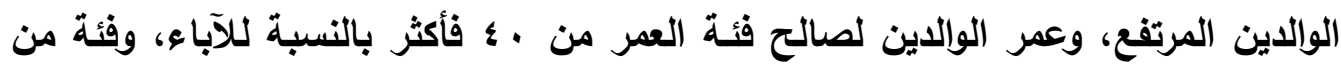

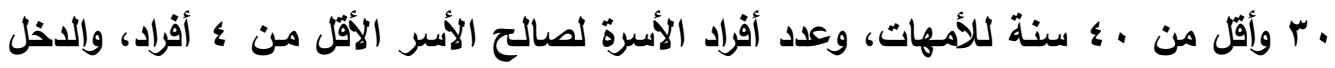


الشهري لصالح الأسر ذوات الدخل المرتفع) كما كشفت عن وجود علاقة طردية دالة بين مستوى وعي الأسرة مع متغيرات (عمر الوالدين، تعليم الوالدين، الدخل الشهري ) وعلاقة

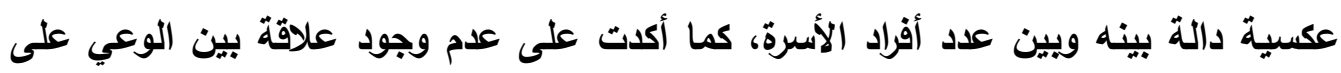
مستوى جميع محاوره مع مدة الزواج وأعمار الأبناء. كما أوضحت أن أهم المتغيرات تأثيراً

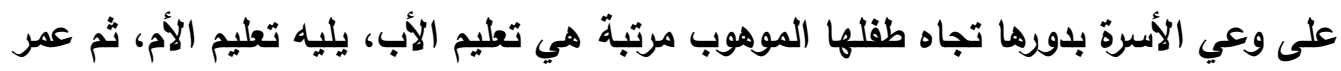

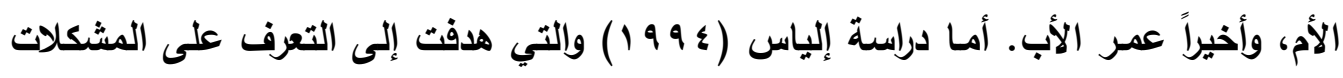

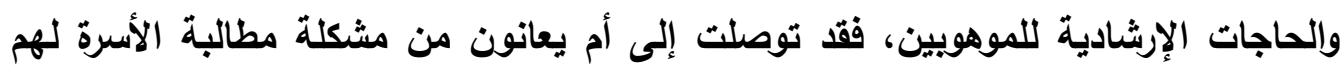
بأداء أكثر مما يستطيعون، وأثثارت إلى وجود فروق في المشكلات الأسرية لصاديه لوالح الطلاب.

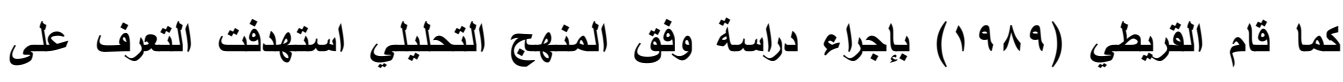
المشكلات التي يواجها المتفوقون عقلياً في البيئة الأسرية والمدرسية وآثارها ودور الخدمات النفية في رعايتهم. وقا خلصت إلى أن المشكلات ومصادر الاحباطات التي يواجها الطقل

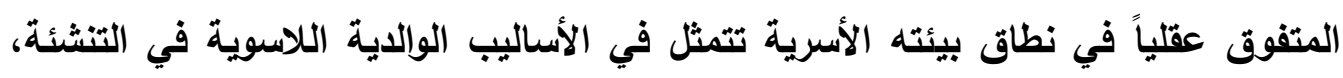
والاتجاهات الأسرية نحو مظاهر التفوق العقلي، وإفتقار البيئة المنزلية للأدوات والوسائل الألئل اللازمة لتنمية استعدادات الطقل ومواهبه، وإغفال الحاجات النفسية للطفل ، وقد توصلت من النات

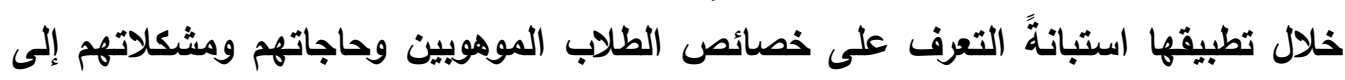

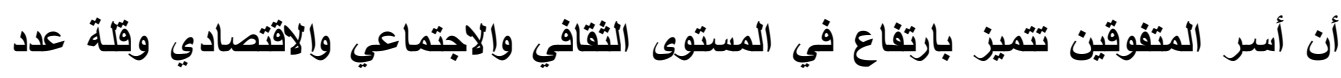

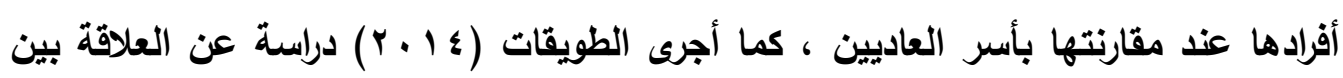

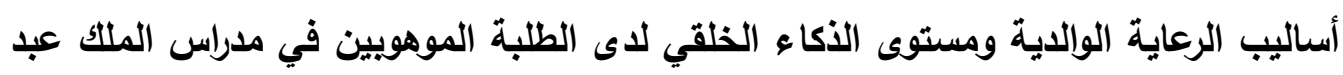

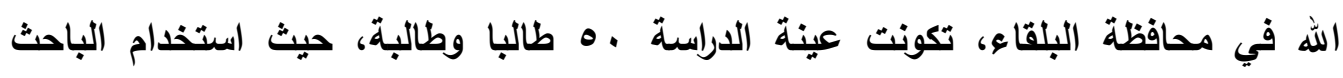

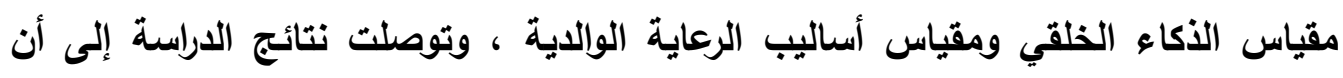

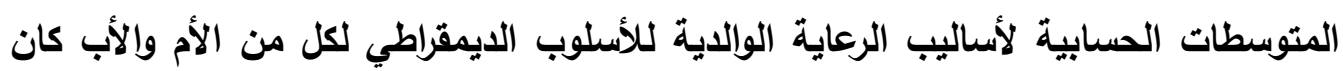

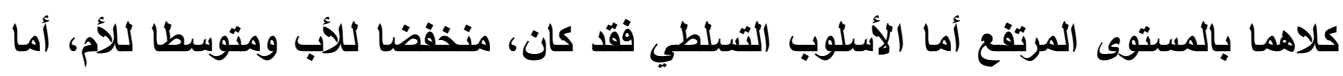
الأسلوب المتساهل فقد كان منخفضا لكليهما. وان المتوسطات الحسابية لجميع أبعاد مقياس المان الأكاء الخلقي كاتت ضمن المستوى المرتفع وان القيم الإحصائية للاختلاف في أساليب الرعاية الوالدية للطلبة الموهوبين تبعا لمتغير الجنس لم تكن دالة إحصائيا، كما بينت النتائج بأن الارتباط بين أسلوب الأم المتساهل والأكاء الخلقي لم تبلغ مستوى الدالالة. وأجرت 
مقحوت (ع ا + Y) دراسة عن أساليب المعاملة الوالدية للمراهقين المتفوقين في شهادة التعليم المتوسط في شهادة التعليم المتوسط، تكونت عينة الدراسة من 1 ـ 1 طالب وطالبة ملتحقين بصفة بثانوية القبة الجديد للرياضيات بالجزائر العاصمة، حيث اعتمدت على مقياسي أساليب المعاملة الو الدية كما يدركها الأبناء ـ بصورتيه (الأب) وصورة (الأم) توصلت نتائج الدراسة باستة إلى أن أغلب والدي أفراد عينة الدراسة (آباء وأمهات) يميلون إلى تبني الأساليب الايجابية

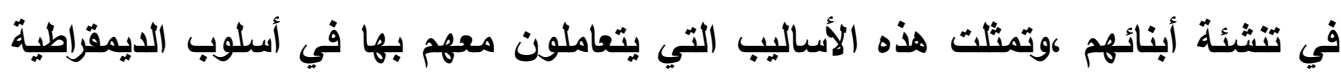

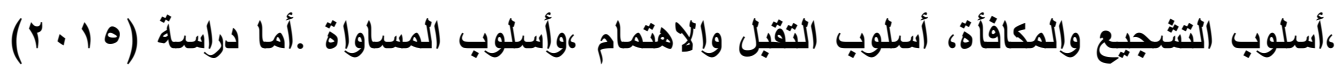
Besnoy, Kevin D.; et al الموهويين ذوي صعويات التعلم في المرحلة الابتدائية ، وتكونت عينة الدراسة (^) من الآباء

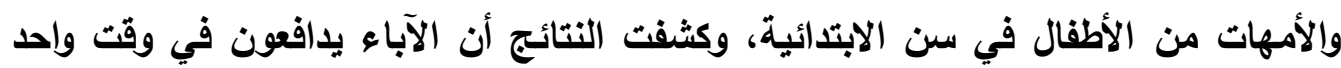

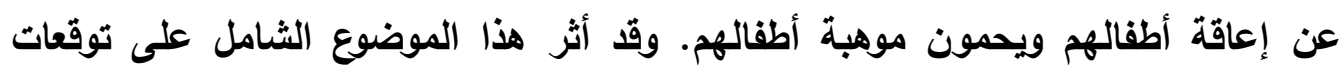
الآباء من نظامهم المدرسي المحلي، مع تسليط الضوء على افتقارهم إلى المعرفة المهنية. وإفتقار الموارد المتاحة التي تركز على الأطفال الموهويبين ذوي صعويات التعلم.

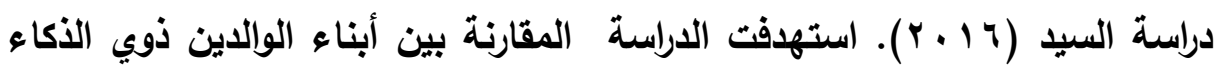
الوجداني المرتفع و أبناء الوالدين ذوي الأكاء الوجداني المنخفض في متغير التفكير الابتكاري للأبناء و ذلك لان الفروق هنا ستعكس الارتباط بين الأكاء الوجداني لدي الوالدين و التفكير

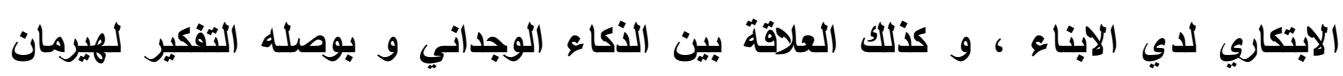

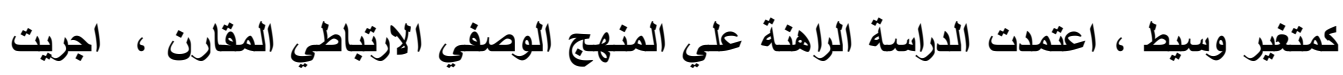

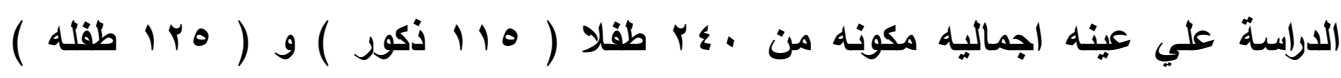

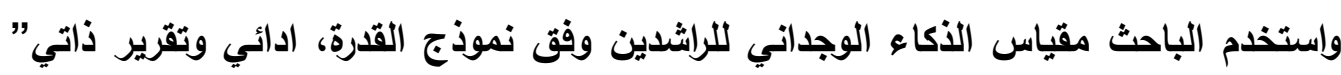

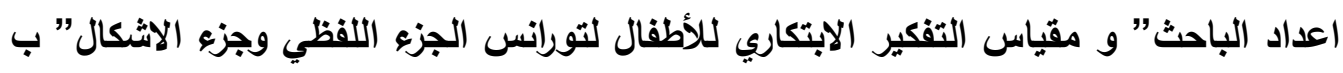

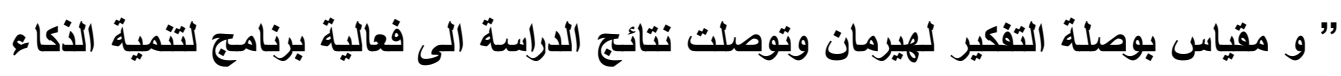

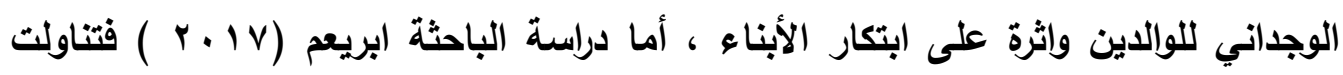

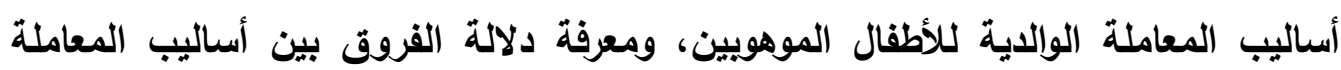

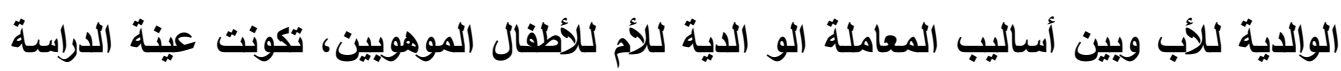

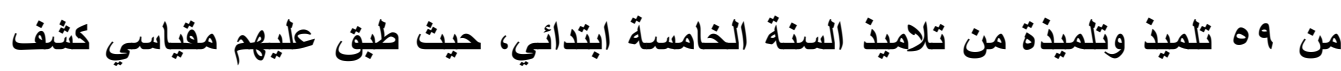


الموهبة، وأساليب المعاملة الوالدية، حيث توصلت نتائج الدراسة إن اكثر أساليب المعاملة الوالدية التي يتعامل بها الوالدين مع الأطفال الموهوبين استخداماً كانت الديمقراطية ،و التقبل

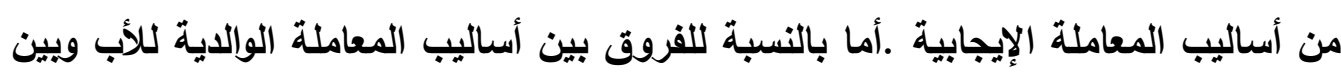

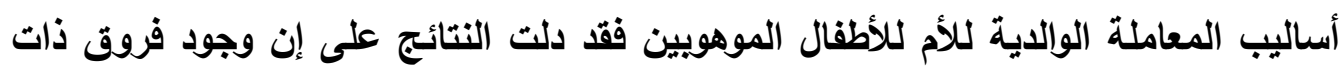
دلالة إحصائية بين الأم والأب في أساليب المعاملة الإيجابية والمتمثلة في كل أسلوبي (الايمقراطية، التقبل) لصالح الأم ، ووجود فروق ذات دلاتلة الإلة إحصائية بين الأم والأب في بعض أساليب المعاملة السلبية والمتمثلة في كل أسلويب (الحماية الزائدة، التفرقة) لصالح الأم فيما يخص أسلوب الحماية الزائدة، ولصالح الأب فيما يخص أسلوب التفرقة، بينما لم

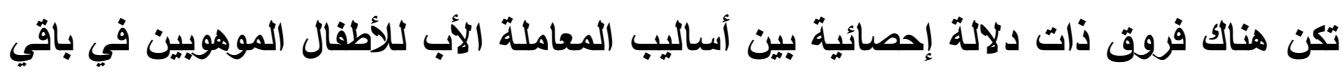

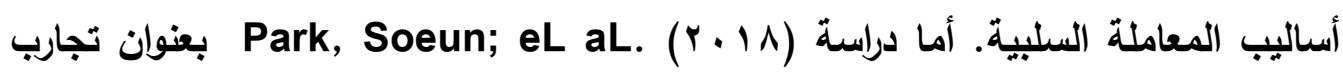
الآباء الأميركيين الآسيويين مع الأطفال الموهويين ذوي صعويات التعلم" حيث يلعب اباء

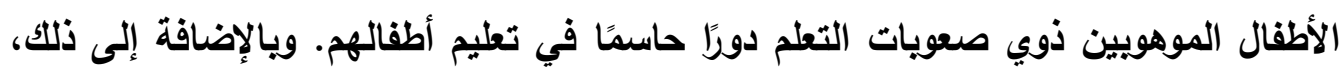
يمكن أن تؤثر السياقات الاجتماعية والثثافية للوالدين، بما في ذللك العرق على على ممارستهما

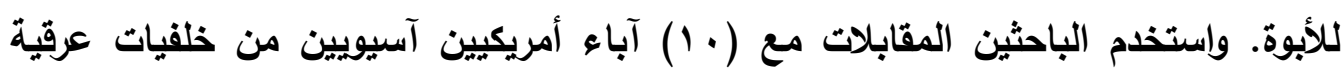

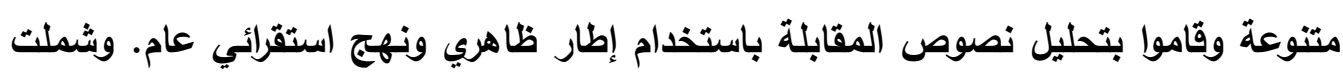

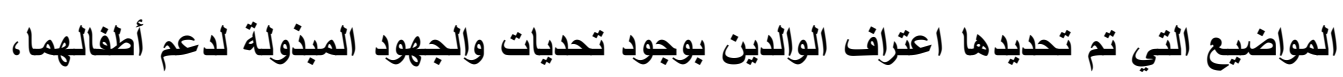
وتصورهم لأوضاعهم الاجتماعية وإلثقافية فيما يتعلق بممارسات الأبوة والأمومة. طور الآباء الأميركيون الآسيويون في هذه الدراسة أساليب أمومة مرنة وجهود مناصرة مستمرة أثناء تنقلهم في الخصائص المعقدة للاستثناءات مرتين في سياقاتهم الثقافية متعددة الطبقات. وتُعَد النتائج مهمة بثكل خاص للممارسين والمربين الذين يعملون مع آباء الأطفال ذوي فئين

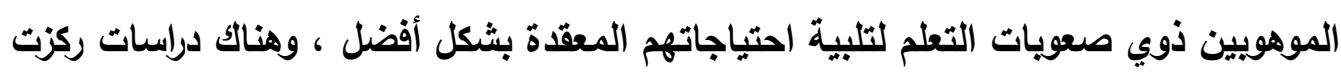

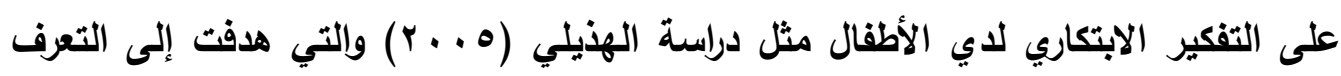
على فاعلية برنامج تدريبي مستثد إلى اللعب في تنمية التفكير الابتكاري لاى الأطفال

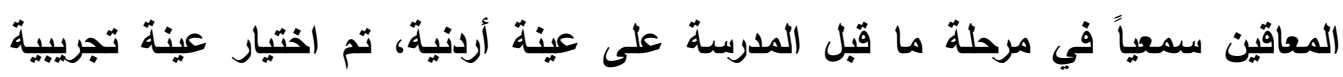
بطريقة قصدية مكونة من (IV) طفلاً وطفلة من مدرسة الرجاء بحافظة الزرقاء، وعينة

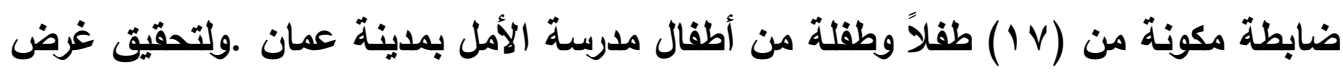


الاراسة تم بناء برنامج تعليمي مستثد إلى اللعب على أفراد المجموعة التجريبية بواقع ( • (ه)

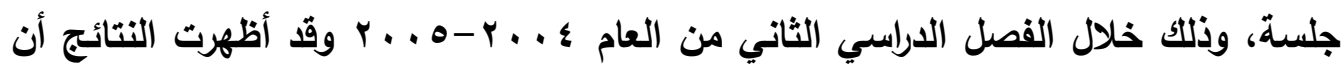
هناك فروقاً ذات دلالة إحصائية في أداء الأطفال على الدرجة الكلية للقياس البعدي لاختبار

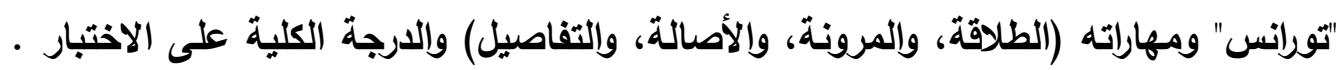

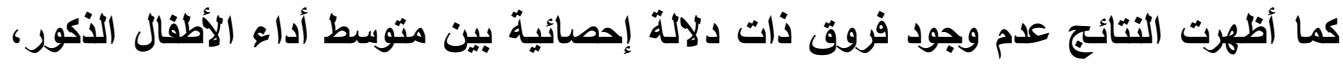
ومتوسط أداء الأطفال الإناث على اختبار "تورانس" للتفكير الابتكاري ومهاراته الأربعة. ويبيت النتائج عدم وجود أثز ذي دلالة إحصائية للتفاعل بين البرنامج والجنس في التفكير الابتكاري

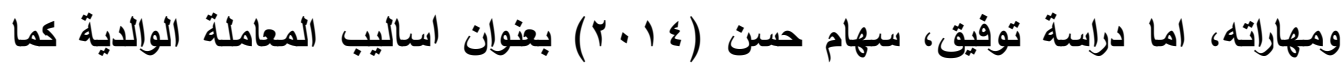
ياركها الأبناء وعلاقتها بالتفكير الابتكاري لدى طلاب المرحلة الثانوية وتكونت العينة من دان طلاب وطالبات الصف الثاني / المرحلة الثانوية في محلية الخرطوم - وحدة الخرطوم شرق.

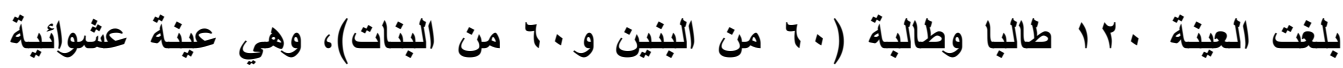

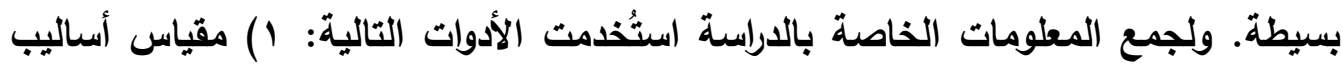

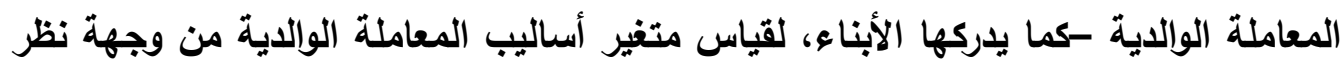
الأبناء (إعداد: أنور رياض - عبد العزيز المغيصيب الو9 ام).، اختبار القدرة على التفكير الابتكاري (إعداد سيد خير الله، ؟ \9 ام)، وهو لقياس متغير القدرة على التفكير الابتكاري للأبناء توصلت الباحثة إلى ان السمة العامة المميزة لأساليب المعاملة الوالدية هي السلبية. ولا توجد علاقة ارتباطية ذات دلالة إحصائية بين أساليب معاملة الأب -كما يدركها الأبناء-

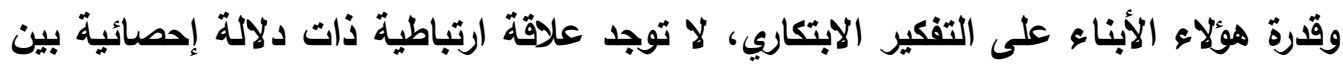

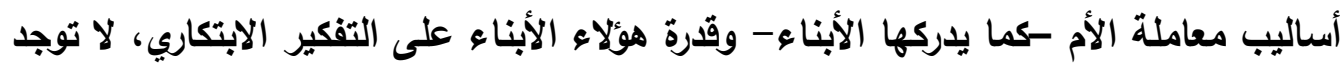
فروق ذوات دلالة إحصائية بين البنين والبنات في أساليب معاملة الأب وأساليب معاملة الأم

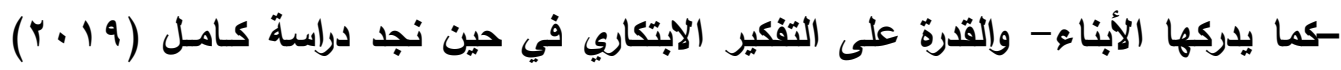

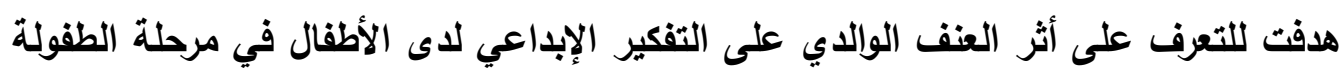

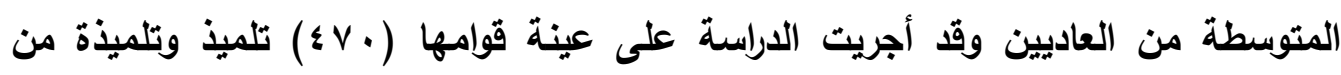

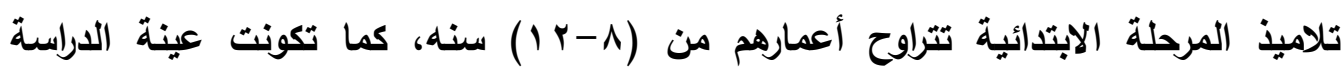
الإكلينيكية من (ع ) تلاميذ من المرحلة الابتدائية وقد تم اختيارهم من بين تلاميذ العينة بناء

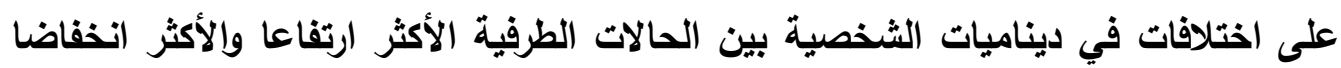


على مقياسي الدراسة كما يوضحها اختبار تفهم الموضوع ، واشتملت الدراسة على أدوات Creative منها- مقياس العنف الوالدي. (إعداد: الباحث)، مقياس التفكير الإبداعي. Thinking

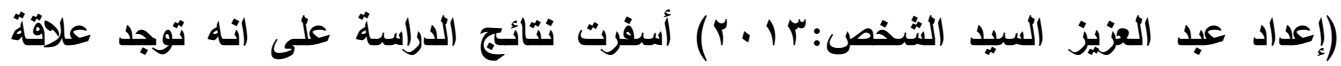

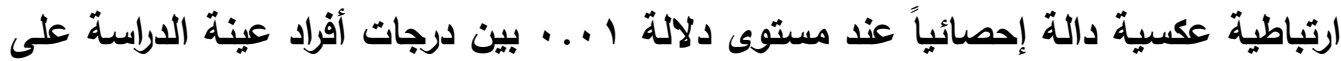
كل أبعاد العنف الوالدي والتفكير الإبداعي لاى أطفال مرحلة الطفولة المتوسطة، وتوجد فروق لهقي دالة إحصائياً عند مستوى دلالة ال ... بين تلاميذ وتلميذات أطفال مرحلة الطفولة المتوسطة الإبية في مستوى العنف الوالدي للأب وفي اتجاه التلاميذ، وتوجد فروق غير دالة إحصائياً عند

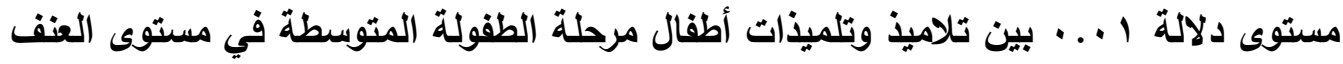

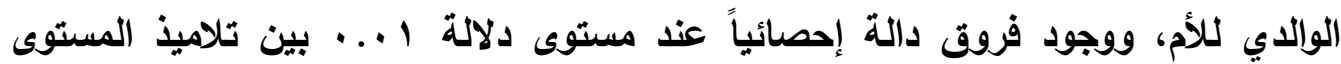

$$
\text { الاجتماعي والاقتصادي في التفكير الإبداعي. }
$$

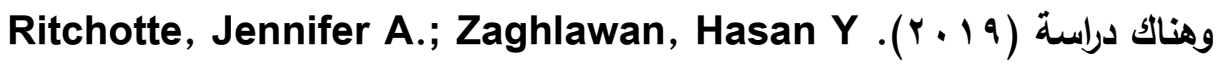

والتي ركزت على دراسة تأثير تدريب الآباء على استخدام استراتيجية استجواب خلال وقت

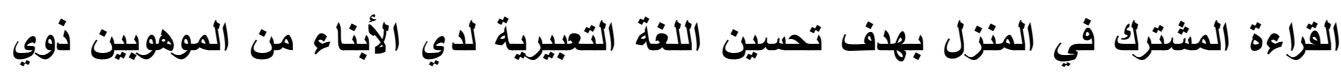
صعويات التعلم وتكونت عينة البحث من أربعة آباء وتم تدريبهم على استخدام أسئلة استنادًا إلى تصنيف بلوم المنقح، مع أطفالهم في المنزل خلال روتين القراءة المشترك، وأثشارت

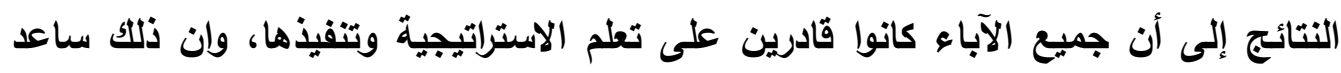

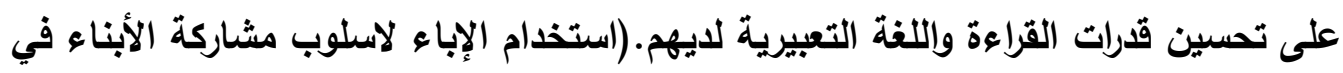
التعليم والقراعة قد يساعد في حل المشكلة الرئيسية لايهم وهي صعويات التعلم).

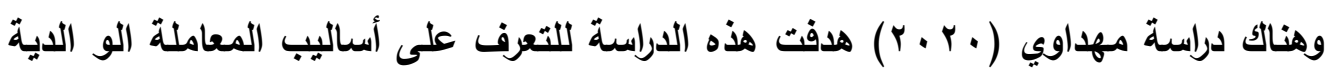

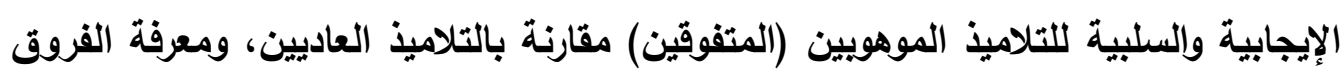

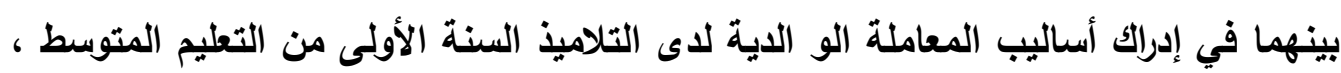

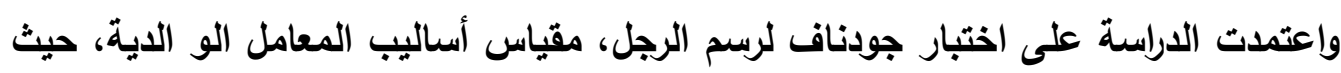

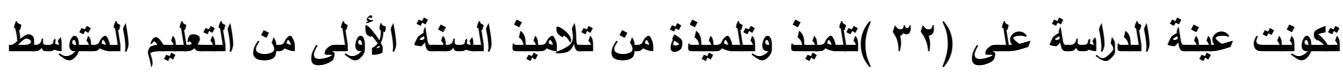

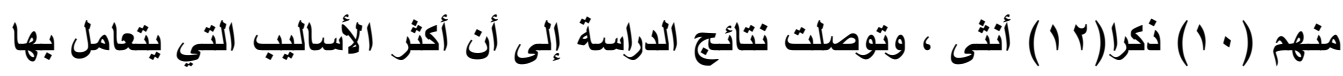

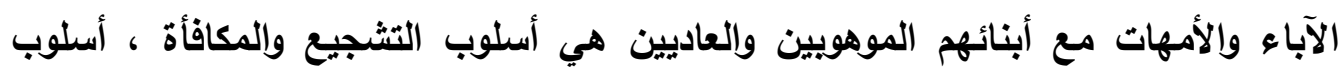


التقبل والاهتمام ، أسلوب الايمقراطية ، ، أما في الأساليب السلبية المتمثلة في (أسلوب النبذ والإهمال وأسلوب الحماية الزائدة) لا توجد فروق ذات دلالة إحصائية بين الأطفال الموهويين

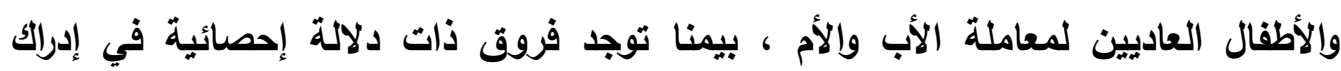
الأساليب السلبية (قسوة والتسلط إثارة الألم النفسي) لمعاملة الأب والأم ، وهناك دالك دراسة Hornby, Garry(2021)Gierczyk, Marcin

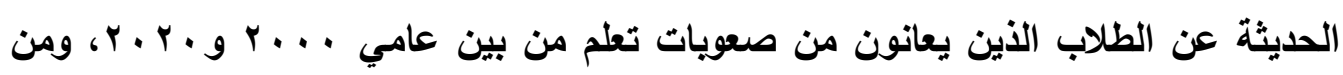

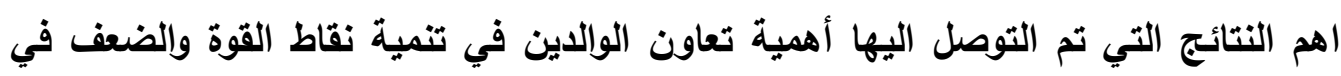
معالجة الصعويات، ودمج الطلاب الموهويون ذوي صعويات التعلم بشكل فعال في بيئات التعليم الثامل،- وهناك دراسة محمد، نسمة (2020) بعنوان العلاقة بين أساليب المعاملة

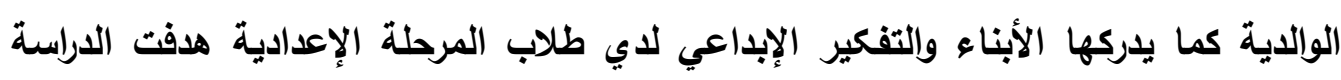

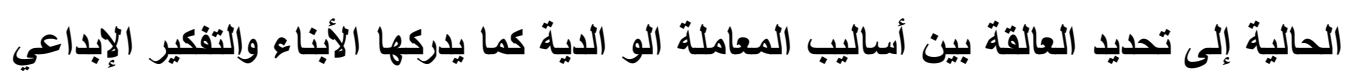

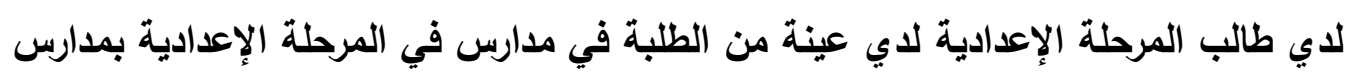
بمدينة ج أكتوير وأيضا الكثف عن الاختلاف في مستويات التفكير الإبداعي وأساليب

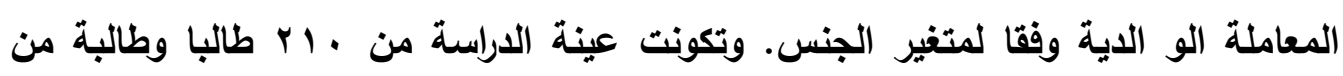

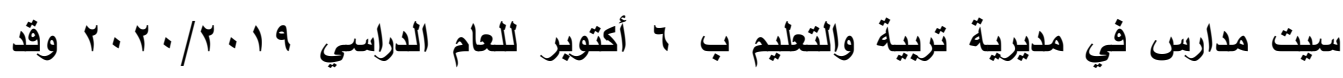
استخدمت الباحثة مقياس أساليب المعاملة الوالدية ومقياس التفكير الإبداعي. وكثفت نتائه نتائج

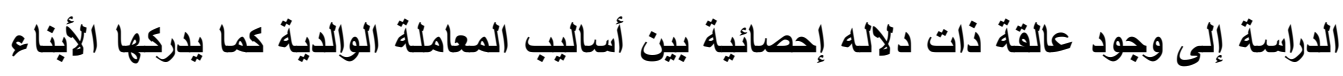
والتتفير الإبداعي لدي طالب المرحلة الإعدادية.

نقد اللدراسات السابقة

وقد مثّل هذا التراث البحثي لهذه الدراسة معيناً ساعد في صياغة وإعداد أبعاد وينود

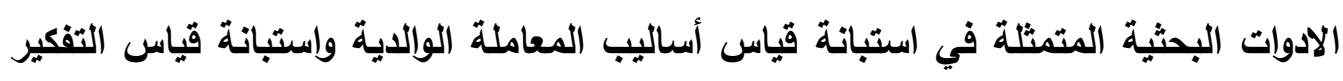

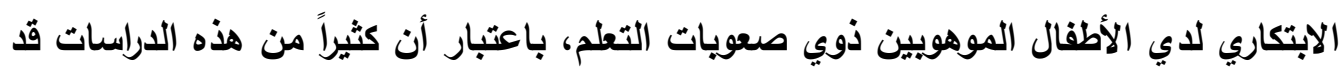

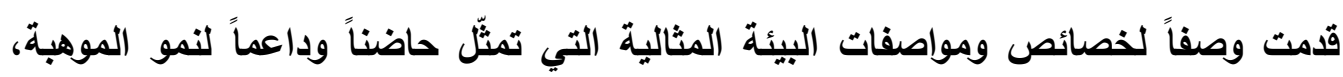

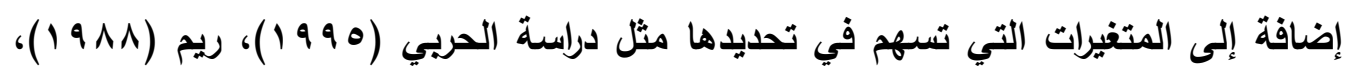

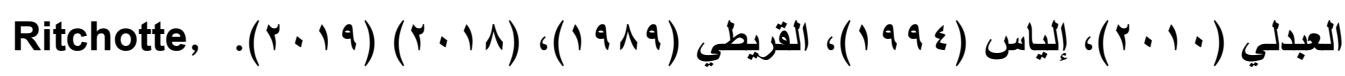
Jennifer A.; Zaghlawan, Hasan Y, Park, Soeun; eL aL. 


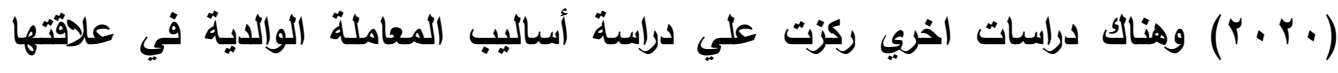

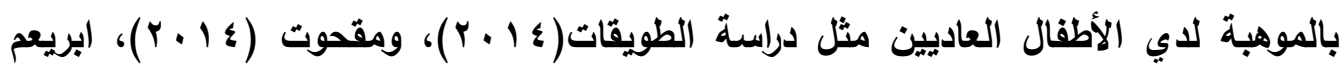

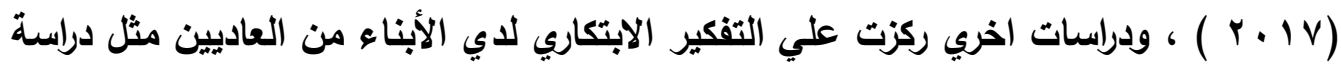

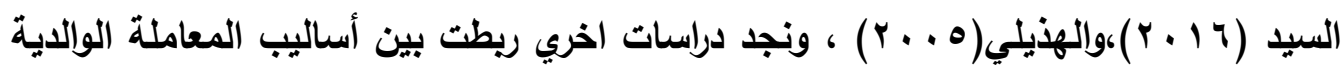

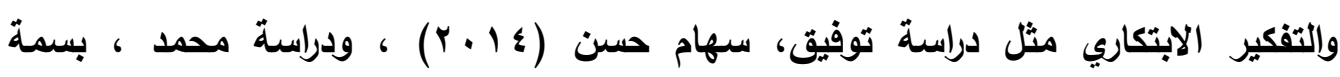

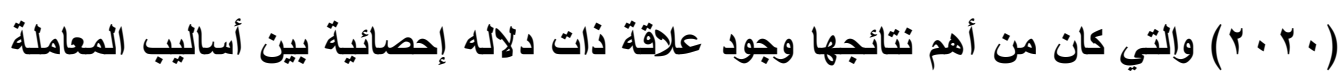

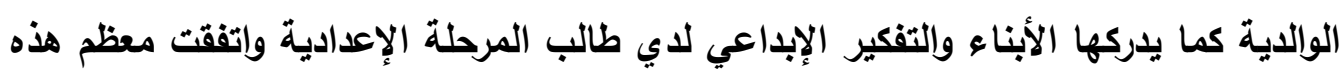
الدراسات على أهمية الأساليب الإيجابية في تعامل الوالدين مع الأبناء الموهويين من الأطفال

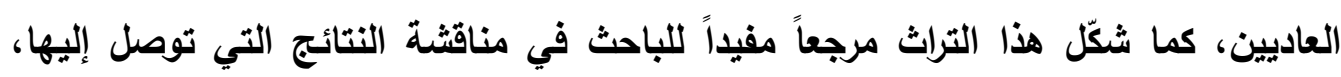
وأعانه في تأكيد تلك النتائج سواء توافقت معها أو اختلفت مما أثرى التتاول البحثي لهذه فئه الدراسة ، وقد حاولت الباحثة في البحث الحالي تتاول فئة لم يتم التركيز عليها في علاقتها بالتفكير الابتكاري وهي فئة الموهويين ذوي صعويات التعلم وهى تمثل الفجوة البحثية التي تحاول الباحثة تغطيتها في هذا البحث. فروض البحث - توجد علاقة ذات دلالة إحصائية بين أساليب المعاملة الوالدية ومستوى التفكير الابتكاري لاي الموهوبين ذوي صعويات التعلم.

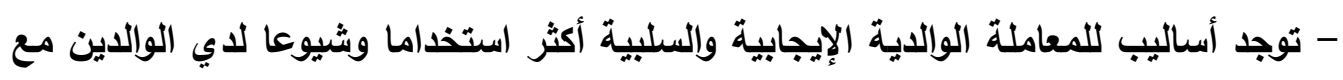
الموهوبين ذوي صعويات التعلم. - هناك فروق ذات دلالة إحصائية بين كلا من الاب والام في استخدام الاساليب الايجابية والسلبية مع الموهويون ذوي صعويات التعلم تبعاً لمتغير الجنس. - - توجد فروق ذات دلالة إحصائية بين متوسطات درجات الموهوبين ذوي صعويات دوبات التعلم على أبعاد استبيان التفكير الابتكاري للموهوبين ذوي صعويات داتهوله التعلم. 


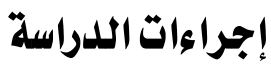

منهج البحث

اعتمدت الباحثة على المنهج الوصفي الارتباطي بطريقة العينة العشوائية المنتظمة

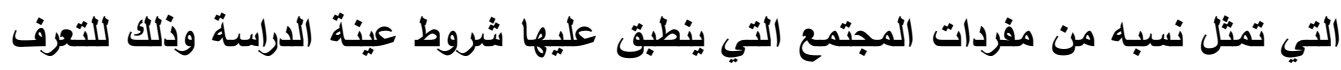

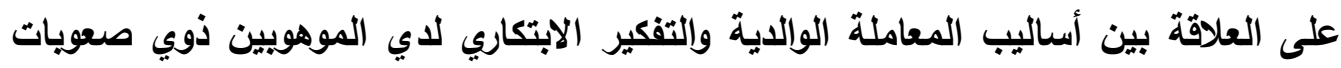
التعلم.

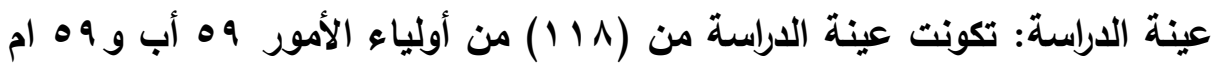

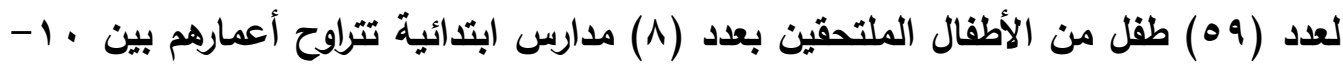

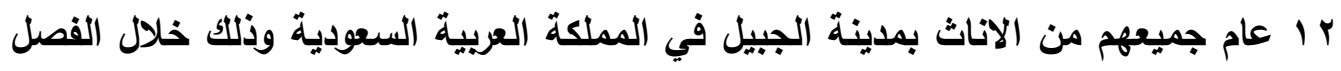

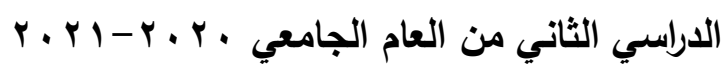

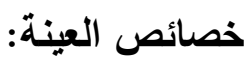

لوصف عينة البحث تم تحديد عدد من المتغيرات الرئيسية (الجنس - المؤهل

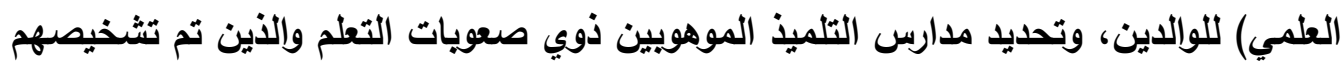
من قبل الدارس وذلك لأجراء التحليلات المختلفة والمتعلقة بالبحث، كما أنها تكون مؤثرات

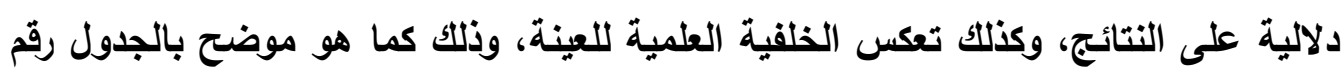

توزيع أفـراد عينة الدراسة:

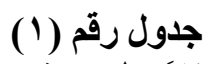

توزيع عينة (الإباء-الأمهات) بناءًُ على متغــيرات الجنس و المؤهل التطليمي

\begin{tabular}{|c|c|c|c|c|}
\hline الإجمالي & $\%$ & التكرارات & \multicolumn{2}{|c|}{ متغيرات عينة الاراسة } \\
\hline \multirow{2}{*}{118} & $50 \%$ & 09 & ام & \multirow{2}{*}{ الجنس } \\
\hline & $50 \%$ & 59 & (ب & \\
\hline \multirow{3}{*}{118} & $\overline{95.76}$ & 113 & بكالوريوس & \multirow{3}{*}{ المؤهل التعليمي } \\
\hline & 4.24 & 5 & ماجيستير & \\
\hline & 0.00 & $\overline{0}$ & ل دكتوراة & \\
\hline
\end{tabular}

تم تطبيق الدراسة على والدي التلاميذ الموهوبين ذوي صعويات التعلم الملتحقين بالبرامج الخاصة في مدارس المرحلة الابتدائية في مدينة الجبيل في السعودية. 


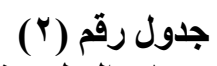

توزيع عينة (الموهوبين ذوي صعوبات التعلم) بناءً على توزيعهم على المدارس

\begin{tabular}{|c|c|c|}
\hline النسبة & عدد الطالبات & أسم المدرسة \\
\hline $12 \%$ & 7 & مدرسة ماريا العالمية \\
\hline $8 \%$ & 5 & مدرسة المعتصم العالمية \\
\hline $14 \%$ & 8 & المدرسة الابتدائية السادسة \\
\hline $10 \%$ & 9 & المدرسة الابتدائية الثامنة \\
\hline $1 \leqslant \%$ & $\wedge$ & المدرسة الابتدائية الثالثة عشر \\
\hline $8 \%$ & 0 & المدرسة الابتدائية الحادية عشر \\
\hline $1 \leqslant \%$ & $\Lambda$ & مدرسة الأبناء بالقاعدة البحرية \\
\hline 10 & 9 & المدرسة الابتدائية الخامسة \\
\hline $1 \ldots \%$ & 89 & المجموع \\
\hline
\end{tabular}

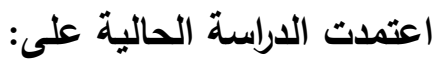

1 - استبيان أساليب المعاملة الوالدية، كما يدركها الأبناء. بصورتيه:(الأب) و(الام) (اعداد (الباحثة)

ץ-أستبيان التفكير الابتكاري لاي التلاميذ الموهوبين ذوي صعويات التعلم (اعداد الباحثة) 1-استبيان اساليب المعاملة الوالدية: من خلال الاطلاع على الأدبيات والدراسات السابقة التي تتاولت أساليب المعاملة الوالدية مثل

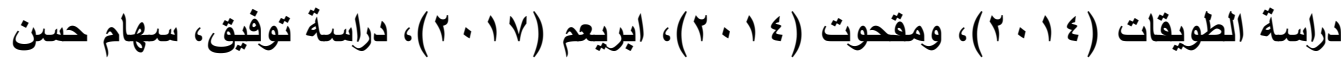

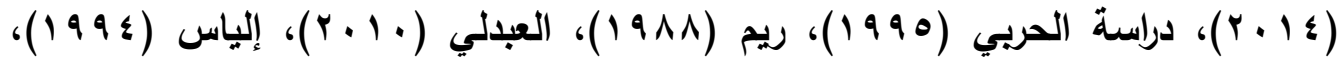

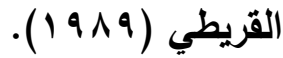

قامت الباحثة بإعداد استبيان أساليب المعاملة الوالدية بهدف: -القياس والمقارنة بين اساليب المعاملة الوادية -التعرف علي بين متوسطات درجات الأمهات والاباء على أبعاد المعاملة الوالدية -التحقق من وجود علاقة بين اساليب المعاملة الوالدية وبين التفكير الابتكاري. مبررات استخدام استبيان أساليب المعاملة الوالدية - ماقعية عبارات المقياس فهو يحتوي على عبارات وثيقة الصلة بأبعاد أساليب المعاملة الوالدية المستخدمة بالدراسة 
- - سهوله عبارات الاستبيان وإمكانية الإجابة عليه بسهوله - - عدم استغراق وقت كبير وسهولة تصحيحه

ويحتوي استبيان أساليب المعاملة الوالدية على ،ه عبارة يتم تقديرها بالتوزيع الثثلاثي (دائما. أحيانا. أبدا)، وكل عبارة من عبارات المقياس تصنف ضمن بعد معين حيث قسمت الباحثة المقياس إلى ^ أبعاد او أساليب وهي كالتالي :. التقبل والاهتمام، الايمقراطية، التشجيع والمكافأة، المساواة، النبذ والإهمال، الحماية الزائدة، القسوة والتسلط، أسلوب أثارة التهات الألم النفسي. توزيع فقرات الاستبانة

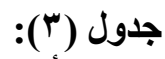

توزيع فقرات الاستبانة حسب الأبعاد وأرقام الفقرات لكل بعد

\begin{tabular}{|c|c|c|c|}
\hline أرقام الفقرات أو العبارات & الفقرات & الأبعـــــاد أو المحاور & 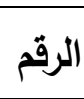 \\
\hline Q1, Q2, Q3, Q4, Q5, Q6 & 6 & 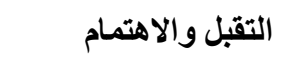 & 1 \\
\hline Q7, Q8, Q9, Q10, Q11, Q12 & 6 & الايمقر اطية & r \\
\hline Q13, Q14, Q15, Q16, Q17, Q18 & 7 & التشجيع و المكافأة & $r$ \\
\hline Q19, Q20, Q21, Q22, Q23, Q24 & 7 & 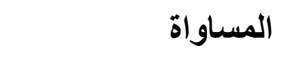 & $\varepsilon$ \\
\hline Q25, Q26, Q27, Q28, Q29, Q30 & 7 & 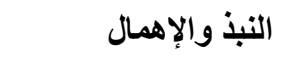 & $\bullet$ \\
\hline Q31, Q32, Q33, Q34, Q35, Q36 & 7 & 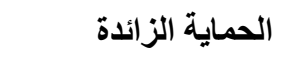 & 7 \\
\hline Q37, Q38, Q39, Q40, Q41, Q42, Q43, Q44 & $\wedge$ & القسوة والتسلط & $v$ \\
\hline Q45, Q46, Q47, Q48, Q49, Q50 & 7 & إثارة الألم النفسي & $\wedge$ \\
\hline & $\mathbf{5 0}$ & \multicolumn{2}{|c|}{ الإجمالي } \\
\hline
\end{tabular}

طريقة تصحيح عبارات الاستبانة

تم استخدام مقياس ليكارت وقد اعطيث قيم متدرجة وفقاً لمقياس ليكرت الثلاثي (دائما. أحيانا. أبدا) فإذا أجاب المفحوص (دائما) تكون درجته (ب)، وإذا أجاب أحيانا تكون درجته (ץ) وإذا أجاب (أبدا)تكون درجته (1) مع مراعاة مسايرة البنود لأبعاد الاستبيان. 
وتم توزيع العبارات وفقاً لأوازن الاختيارات بحيث يكون البند رقم (1) خاص بيعد التقبل

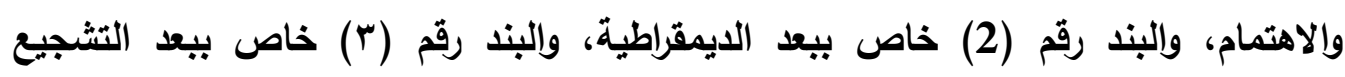
والمكافأة، والبند رقم (؛)خاص ببعد المساواة، والبند رقم (ه) خاص ببعد النبذ والإهمال،

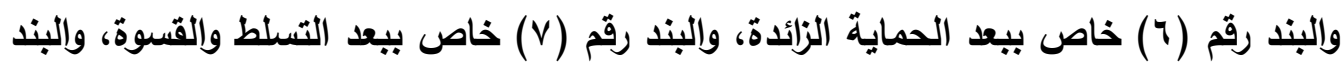

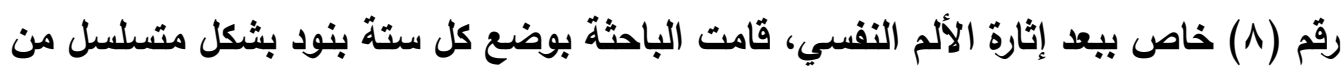

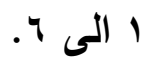

\section{الخصائص السيكو متزية للأداة الأولى ( أساليب المعاملة الوالدية )}

اولاً: صدق الأداة: validity

لمعرفة درجة الصحة التي تقيس فيها الاستبانة ما أعلات لقياسه قامت الباحثة بالتأكد

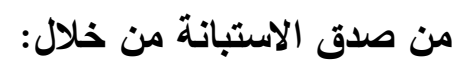
أ. الصلق الظاهري (صلدق المحكميز ):

قامت الباحثة بعرض الاستبانتين بصورتهم الأولية على (ه) من المدكين المكين في

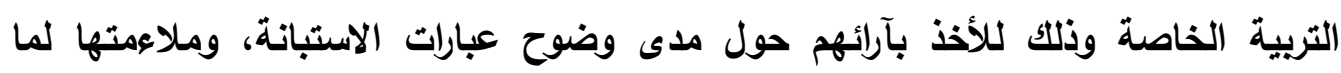
وضعت لقياسه، ومدى مناسبة عبارات الاستبانة للبعد الذي تنتمي اليه، ويناء على ملاحظات

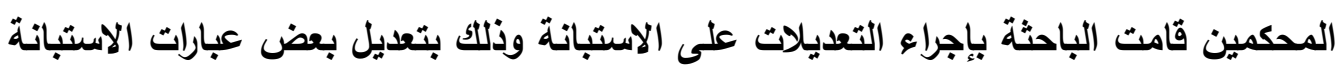

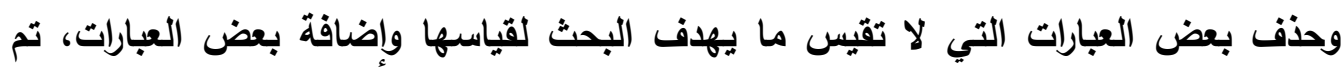
إخراج الاستبانتين بالصورة النهائية.

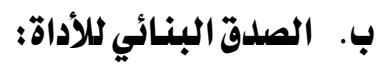
(Spearman - Brown Formula استخدمت الباحثة معامل ارتباط سييرمان لمعرفة مدى ارتباط كل بعد من أبعاد الاستبانة بالدرجة الكلية لفقرات الاستبانة كما هو الهانيان

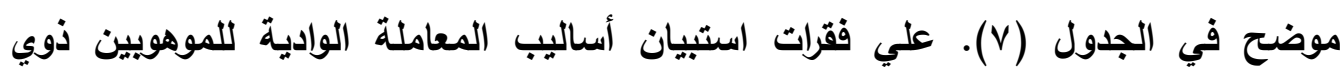

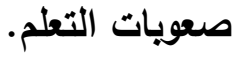


أ.م. د. يمني اليماني: أستاذ علم النفس المشارك -جامعة الأردن

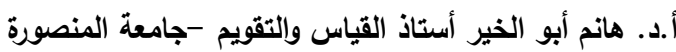

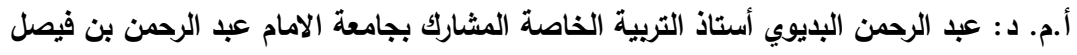
د. عزة عافية: أستاذ مساعد التربية الخاصة -جامعة الامام عبد الرحمن بن فيصل د. إيمان عطوي أستاذ الصحة النفسية المساعد بجامعة الامام عبد الرحمن بن فيصل.

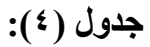

معامل ارتباط سبيرمان بين كل فقرة من فقرات كل محور والارجة الكلية للمحور الخاص بها

\begin{tabular}{|c|c|c|}
\hline تفسير درجة الارتباط & 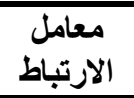 & أبعـــــاد الاستبانة \\
\hline ارتباط طردي قوي جداً معنوي عند مستوى دلالة (1 + . ) & $.922 * *$ & التقبل والاهتمام \\
\hline ارتباط طردي قوي جداً معنوي عند مستوى دلالة (1 + . ) & $.845 * *$ & الديمقر اطية \\
\hline ارتباط طردي قوي جداً معنوي عند مستوى دلالة (1 + • ) & $.818 * *$ & التشجيع والمكافأة \\
\hline ارتباط طردي قوي جداً معنوي عند مستوى دلالة (1 + • ) & $.911 * *$ & المساواة \\
\hline ارتباط طردي قوي جداً معنوي عند مستوى دلالة (1 +. ·) & $.845 * *$ & النبذ والإهمال \\
\hline ارتباط طردي قوي جداً معنوي عند مستوى دلالة (1 +. •) & $.818 * *$ & الحماية الزائدة \\
\hline ارتباط طردي قوي جداً معنوي عند مستوى دلالة (1 +. •) & $.855 * *$ & أسلوب القسوة والتسلط \\
\hline ارتباط طردي قوي جداً معنوي عند مستوى دلالة (1 +. •) & $.987 * *$ & أسلوب اثُارة الألم النفسي \\
\hline $\begin{array}{l}\text { *. Correlation is significant } \\
* * \text {. Correlation is significan }\end{array}$ & $\begin{array}{l}\text { the }(0.0 \\
\text { the }(0.0\end{array}$ & $\begin{array}{l}\text { level } \\
\text { level }\end{array}$ \\
\hline
\end{tabular}

من خلال الجدول (ء) يتضح لنا بأن قيم معامل الارتباط لاي الابعاد تراوحت بين

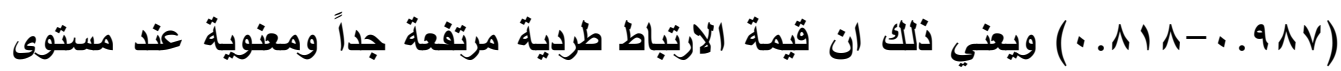

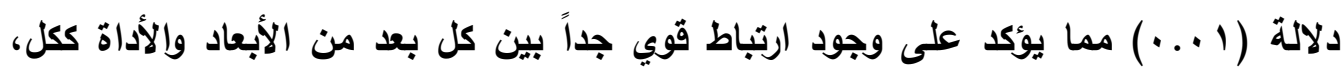
وعليه يمكن القول إن جميع أبعاد الأداة صادقة لما وضعت لله. 


\section{Reliability ثبات الأداة}

تم تقدير الثبات العام للاستبانة على أفراد العينة الاستطلاعية عن طريق استخدام معامل ألفا كرونباخ Cronbach's Alpha والتجزئة النصفية Split-Half وكانت النتائج كما في

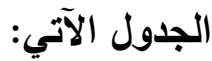

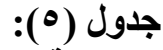

معامل الثبات (ألفا كرونباخ والتجزئة النصفية) على استبيان أساليب المعاملة الو الدية

\begin{tabular}{|c|c|c|c|}
\hline $\begin{array}{c}\text { التجزئة النصفئة } \\
\text { Split-Half Coefficien }\end{array}$ & $\begin{array}{c}\text { ألفا كرونباخ } \\
\text { Cronbach's Alpha }\end{array}$ & العبارات & ثبات عينة الاستبانة \\
\hline 0.936 & 0.934 & 0. & جميع فقرات \\
\hline
\end{tabular}

يتضح من الجدول رقم (0) ارتفاع معدل الارتباط والاتساق الداخلي لفقرات الاستبيان

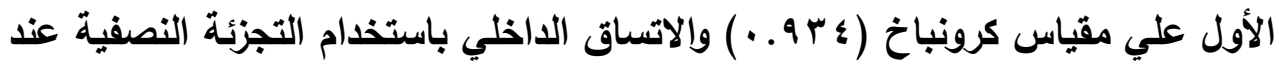
درجة ( ه 9 ه • ) مما يؤكد ثبات فقرات استبيان أساليب المعاملة الوادية. جدول (7) (ج):

معاملات الثبات (ألفا كرونباخ والتجزئة النصفية) بين كل محور من محاور الاستبانة مع الارجة الكلية لـلاستبانة

\begin{tabular}{|c|c|c|c|}
\hline $\begin{array}{c}\text { التجزئة النصفئة-Half } \\
\text { Split-Haeficient } \\
\text { Coeficis }\end{array}$ & $\begin{array}{c}\text { ألفا كرونباخ } \\
\text { Cronbach's } \\
\text { Alpha } \\
\end{array}$ & العبارات & الأبعاد العامة ومحاور \\
\hline 0.948 & 0.968 & 9 & التقبل و الاهتمام \\
\hline 0.936 & 0.950 & 7 & الايمقراطية \\
\hline 0.943 & 0.977 & 9 & التشجيع والمكافأة \\
\hline 0.976 & 0.958 & 7 & المساواة \\
\hline 0.998 & 0.911 & 7 & النبذ والإهمال \\
\hline 0.965 & 0.913 & 7 & الحماية الزائدة \\
\hline 0.945 & 0.922 & $\Lambda$ & أسلوب القسوة والتسلط \\
\hline 0.931 & 0.987 & 9 & أسلوب اثارة الألم النفسي \\
\hline 0.943 & 0.947 & 0. & معامل الثباتة الكلي \\
\hline
\end{tabular}

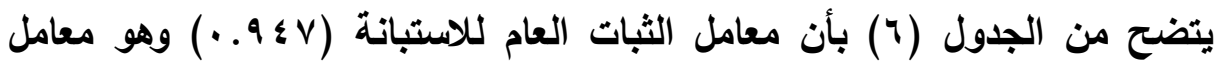
ثبات مرتفع جداً عن الحد الأدنى لقبول الاستبانة وهو ( . . ؟ . .) وهذا يدل على أن الاستبانة تتمتع بدرجة عالية من الثبات ويمكن الاعتماد عليها في التطبيق الميداني للاراسة. 
- الأداة الثانية: مقياس التفكير الابتكاري لدي التتلاميذ الموهوبين ذوي صعويات التعلم من خلال الاطلاع على الأدبيات والدارسات السابقة التي تتاولت التفكير الابتكاري لاي فئات الموهويين والعاديين مثل اختبار القدرة على التفكير الابتكاري (إعداد سيا خير الله،

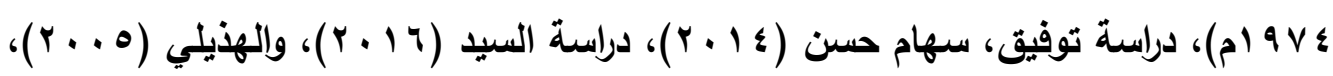
مقياس التفكير الإبداعي. Creative Thinking (إعداد: تورانس: 9 ( 9 ) ) قامت الباحثة بإعداد استبيان التفكير الابتكاري بهدف: - قياس مستوي التفكير الابتكاري (الاصالة -الطلاقة - المرونة - إدراك التفاصيل) لاي الأطفال الموهوبين ذوي صعويات التعلم. - قياس العلاقة بين أساليب المعاملة الوالدية ومستوي التفكير الابتكاري لاي التلاميذ الموهوبين ذوي صعويات التعلم.

مبررات استخدام استبيان أساليب المعاملة الواللية - توظيف عبارات تستطيع قياس مستوي التفكير الابتكاري لدي فئة الموهويين ذوي الصعويات

- - سهوله عبارات الاستبيان وإمكانية الإجابة عليه بسهوله - عدم استغراق وقت كبيز وسهولة تصحيحه تكونت أداة البحث الثانية من اب فقرة موزعين على أربعة ابعاد هما الاصالة والطلاقة والمرونة وإدراك التفاصيل يتم توزيعها على الإباء والامهات لمعرفة مدي توفرها لدي

\section{توزيع فقرات الاستبانة}

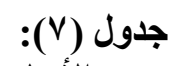

توزيع فقرات الاستبانة حسب الأبعاد وأرقام الفقرات لكل بعد

\begin{tabular}{|c|c|c|c|}
\hline أرقام الفقرات أو العبارات & الفقرات & الأبعــــــاد أو & 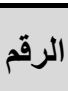 \\
\hline Q8, Q9, Q10, Q11, Q12, Q13, Q14 & $\mathrm{v}$ & الطلاقة & $r$ \\
\hline Q15, Q16, Q17, Q18, Q19, Q20, Q21 & $\mathrm{v}$ & المرونة & $\Gamma$ \\
\hline $\mathrm{Q1}, \mathrm{Q2}, \mathrm{Q3}, \mathrm{Q4}, \mathrm{Q5}, \mathrm{Q6}, \mathrm{Q7}$ & $\bar{v}$ & الاصالة & \\
\hline Q22, Q23, Q24, Q25, Q26, Q27, Q28 & $\mathrm{V}$ & إدرالك التفاصيل & $\xi$ \\
\hline \multicolumn{2}{|l|}{$r \wedge$} & \multicolumn{2}{|l|}{ الإجمالي } \\
\hline
\end{tabular}


طريقة تصحيح مقياس التفكير الابتكاري للدي التلاميذ الموهوبين ذوي صعوبات التعلم

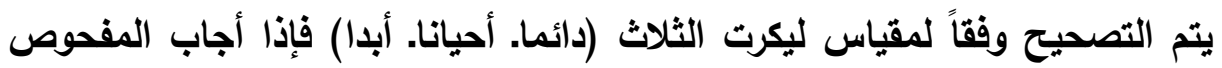
(دائما) تكون درجته (ب)، وإذا أجاب أحيانا تكون درجته (ץ) وإذا أجاب (أبدا)تكون درجته

الخصائص السيكو مترية للأداة الثانية (التفكير الابتكاري لدي الأطفال الموهوبين ذوي صعوبـات

التعلم )

اولاً: صلدق الأداة: validity لمعرفة درجة الصحة التي تقيس فيها الاستبانة ما أعدت لقياسه قامت الباحثة بالتأكد من صدق الاستبانة من خلال: أ. الصدق الظاهري ( صلدق المحكميز ) :

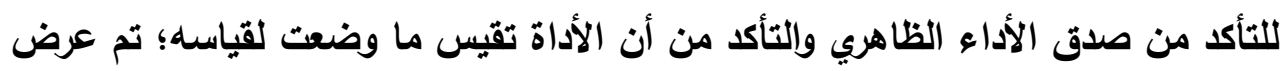
الاستبانة على (؟) محكمين من ذوي الاختصاص والخبرة في التربية الخاصة وعلم النفس؛

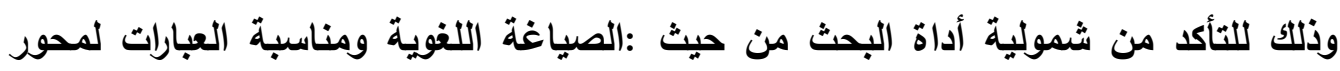

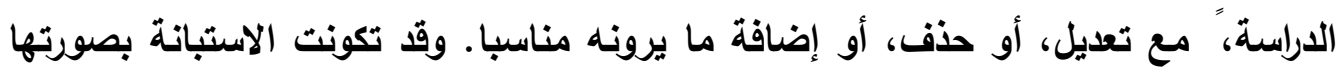

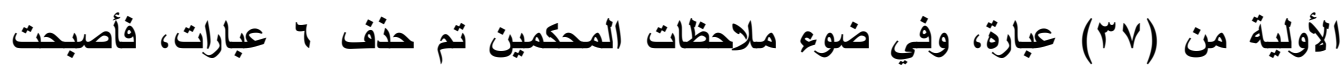

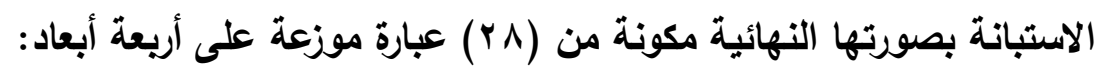

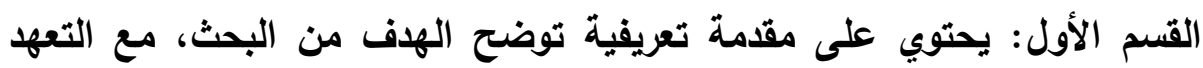
بالسرية التامة، واستخدام المعلومات بسرية تامة .القسم الثاني: يتكون من البيانات الأولية والمتمثلة في الاسم (اختياري - الجنس - المؤهل العلمي). القسم الثالث: استبانة التفكير الابتكاري، وتحتوي على أريعة أبعاد، ومكونة من (r^) الاختيارات التي على الوالدين اختيارها طبقا لمدى الموافقة كالآتي:

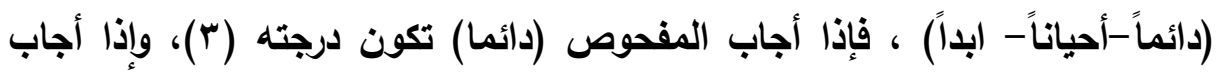
أحيانا تكون درجته (Y) وإذا أجاب (أبدا) تكون درجته (1) مع مراعاة مسايرة البنود لأبعاد

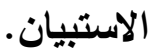


المحكمين للأداة الثانية

أ.م. د. يمني اليماني: أستاذ علم النفس المشارك -جامعة الأردن الفنانه

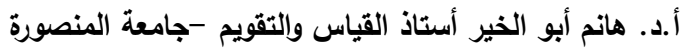

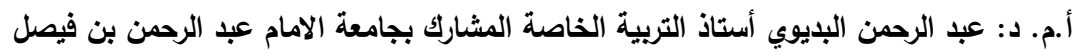
د. عزة عافية: أستاذ مساعد التربية الخاصة -جامعة الامام عبد الرحمن بن فيصل

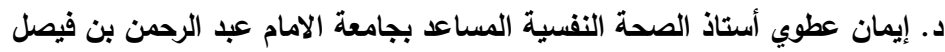

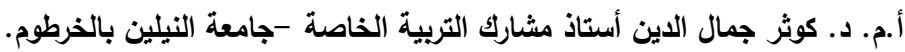
ب. الصدق البنائي للأداة: استخدمت الباحثة معامل ارتباط سيبرمان (Spearman - Brown Formula) لمعرفة مدى ارتباط كل بعد من أبعاد الاستبانة بالدرجة الكلية لفقرات الاستبانة كما هو موضح في الجدول (^). علي فقرات استبيان التفكير الابتكاري لاي الموهويين ذوي صعويات التعلم.

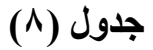

معامل ارتباط سبيرمان بين كل فقرة من فقزات كل محور والدرجة الكلية للمحور الخاص بها

\begin{tabular}{|c|c|c|}
\hline تفسير درجة الارتباط & الارتباط معامل & أبعــــاد الاستبانة \\
\hline ارتباط طردي قوي جداً معنوي عند مستوى دلالة & $.876 * *$ & الطلاقة \\
\hline ارتباط طردي قوي جداً معنوي عند مستوى دلالة & $.852 * *$ & المرونة \\
\hline ارتباط طردي قوي جداً معنوي عند مستوى دلالة & $. \wedge \leq 0 * *$ & الاصالة \\
\hline ارتباط طردي قوي جداً معنوي عند مستوى دلالة & $.856 * *$ & إدراك التفاصيل \\
\hline \multicolumn{3}{|c|}{$\begin{array}{l}* \text {. Correlation is significant at the }(0.05) \text { level } \\
* * \text {. Correlation is significant at the }(0.01) \text { level }\end{array}$} \\
\hline
\end{tabular}

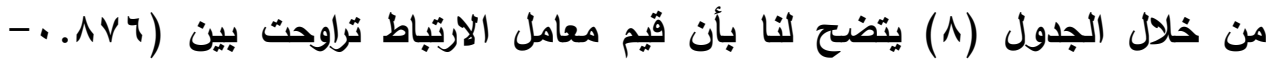
๑ ^^. • ) ويعني ذلك ان قيمة الارتباط طردية مرتفعة جداً ومعنوية عند مستوى دلالة ( 1 ( . ) مما يؤكد على وجود ارتباط قوي جداً بين كل بعد من الأبعاد الثلاثة والأداة ككل.

Reliability شبات الأداة تم تقدير الثبات العام للاستبانة على أفراد العينة عن طريق استخدام معامل ألفا كرونباخ Cronbach's Alpha 
النصفية Split-Half وكانت النتائج كما في الجدول الآتي:

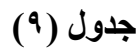

معامل الثبات (ألفا كرونباخ و التجزئة النصفية) على (مقياس التفكير الابتكاري لدي التلاميذ الموهوبين ذوي صعوبات التعلم)

\begin{tabular}{|c|c|c|c|}
\hline $\begin{array}{c}\text { التجزءة النصفية } \\
\text { Split-Half Coefficient }\end{array}$ & $\begin{array}{c}\text { ألفا كرونباخ's Alpha } \\
\text { Cronbach's }\end{array}$ & عدد العبارات & ثبات عينة الاستبانة \\
\hline 0.977 & 0.981 & TI & جميع فقرات الاستباتة \\
\hline
\end{tabular}

يتضح من الجدول رقم (9) ارتفاع معدل الارتباط والاتساق الداخلي لفقرات المقياس

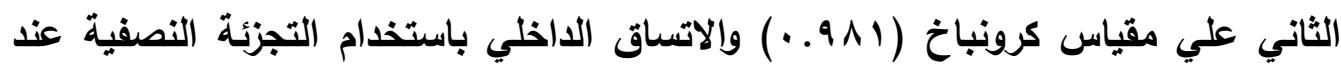
درجة (ه 9 ه · ) مما يؤكد ثبات فقرات مقياس التفكير الابتكاري لدي التلاميذ الموهويين ذوي صعويات التعلم.

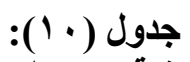

معاملات الثبات (ألفا كرونباخ والتجزئة النصفية) بين كل محور من محاور الاستبانة مع الدرجة الكلية

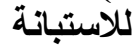

\begin{tabular}{|c|c|c|c|}
\hline $\begin{array}{l}\text { التجزئة النصفية } \\
\text { Split-Half } \\
\text { Coefficient }\end{array}$ & $\begin{array}{c}\text { ألفا كرونباخ } \\
\text { Cronbach's Alpha }\end{array}$ & عدد العبارات & الأبعاد العامة ومحاور \\
\hline .826 & .846 & $\mathrm{~V}$ & الطلاقة \\
\hline .842 & .882 & $\mathrm{~V}$ & المرونة \\
\hline . &.$\wedge 09$ & V & الاصالة \\
\hline .836 & .876 & V & إدراك التفاصيل \\
\hline 0.823 & 0.848 & $r \wedge$ & معامل الثبات الكلي \\
\hline
\end{tabular}

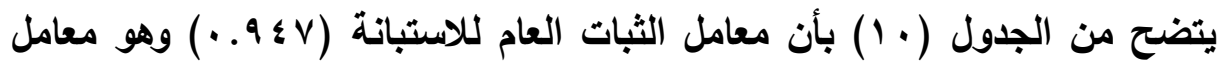
ثبات مرتفع جداً عن الحد الأدنى لقبول الاستبانة وهو ( . . ا . .) وهذا يدل على أن الاستبانة تتمتع بلرجة عالية من الثبات ويمكن الاعتماد عليها في التطبيق الميداني للاراسة. نتائج اللدراسة :

نص الفرضية الأولى: هناك علاقة ذات دلالة إحصائية بين أساليب المعاملة الوالدية ومستوى التفكير الابتكاري لاي الموهوبين ذوي صعويات التعلم.

وللتحقق من صحة هذه الفرضية تم استخدام معامل ارتباط بيرسون جدول رقم (11) حيث توصلنا على النتائج الموضحة في الجدول التالي: ملي: 


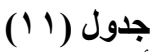

معاملات الارتباط بيرسون بين محاور أساليب المعاملة الوالدية ومحاور التفكير الابتكاري

\begin{tabular}{|c|c|c|c|c|}
\hline إدراك التفاصيل & الاصلالة & العرونة & الطلاقة & أساليبي التفكير الابتكاري المعاملة الموالهية \\
\hline.$\vee \vee \wedge * *$ & $. V V \leqslant * *$ & $. \wedge \leqslant \curlyvee * *$ &.$\wedge 9 \vee * *$ & التقبل والاهتمام \\
\hline.$\wedge \vee \nabla * *$ &.$\vee 9 \wedge * *$ & VTV ** & . $\wedge \neg \% * *$ & اللايبقراطية \\
\hline.$\vee \wedge \wedge * *$ &.$V \cdot r * *$ &.$\wedge \cdot 9 * *$ &.$\wedge \vee \neg * *$ & التشجبيع والمكافأة \\
\hline $.941 \% *$ & .Vイץ** & $. v 0 \leq * *$ &.$v \cdot 9 * *$ & المساو/ة \\
\hline.$-\vee \vee \vee * * *$ &.$-\Lambda \cdot \Lambda * *$ &.$-\vee \wedge \neg * *$ &.$-\wedge 9 \cdot * *$ & النببَ والإهمال \\
\hline$-.009 *$ &.$- \vee \wedge \cdot * *$ & $-.704 * *$ & $.0 \vee 9 *$ & الحمايةة النزائدة \\
\hline$-.0 Y 1 *$ & $-.7 \vee \wedge * *$ &.$- \vee \wedge q * *$ & $-. \wedge \leqslant 0 * *$ & أسلوب القسوة والتسلط \\
\hline$-.70 \cdot * *$ &.$- V Y \mu * *$ &.$- \wedge \vee \cdot * *$ & $-.9 V Y * *$ & أسلوب إثارة الألم النفسسي \\
\hline \multicolumn{5}{|c|}{$\begin{array}{l}* \text {. Correlation is significant at the }(0.05) \text { level } \\
* * \text {. Correlation is significant at the }(0.01) \text { level }\end{array}$} \\
\hline
\end{tabular}

يوضح الجدول السابق رقم (11) إلى وجود علاقة إيجابية داله إحصائيا بين أبعاد

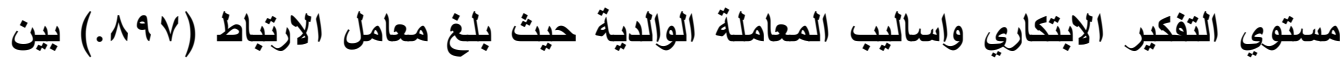
أسلوب التقبل والاهتمام وأسلوب الطلاقة وهي علاقة ايجابية، كما يتضح وجود علاقة إيجابية بين بعد أسلوب التقبيل والاهتمام وأسلوب المرونة حيث بلغ معامل الارتباط (ب ع ^.) ، وايضاً وجود علاقة ايجابيه بين أسلوب التقبل والاهتمام وأسلوب الاصالة حيث بلغ معامل الارتباط

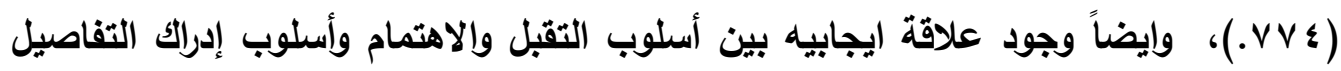

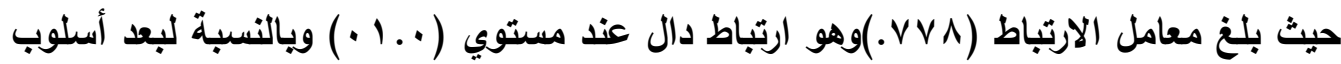

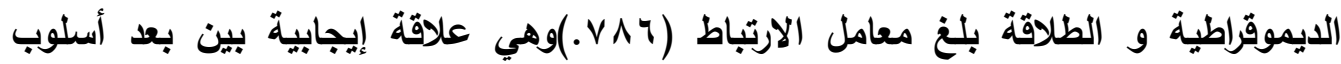
الديموقراطية و الطلاقة ، كما يتضح إلي وجود علاقة ايجابية بين بعد أسلوب الايموقراطية و

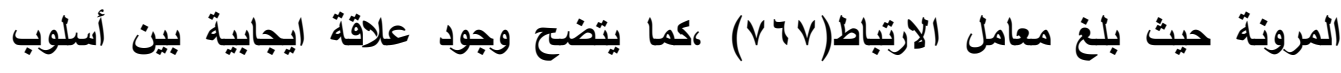
الديموقراطية وأسلوب الاصالة بلغ معامل الارتباط (VA VA.) ، وايضاً وجود علاقة ايجابيه بين أسلوب الديموقراطية وأسلوب إدراك التفاصيل حيث بلغ معامل الارتباط (هvo. دال عند مستوي (0.01) ويالنسبة لبعد أسلوب التشجيع والمكافأة والطلاقة حيث بلغ معامل الارتباط (AV7.) وهي علاقة ايجابيه بين بعد أسلوب التشجيع والمكافأة وأسلوب الطلاقة،

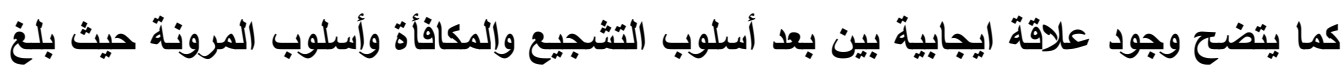
معامل الارتباط (9.1.)، كما يتضح وجود علاقة ايجابية بين أسلوب التشجيع والمكافأة 
وأسلوب الاصالة حيث بلغ معامل الارتباط (r · V.)، وايضاً وجود علاقة ايجابية بين أسلوب

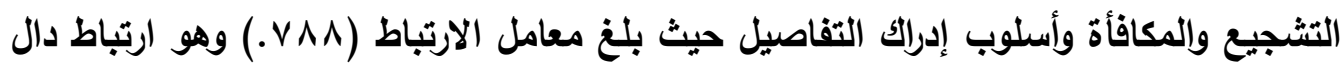
عند مستوي (... (.) ويالنسبة لبعد أسلوب المساواة وأسلوب الطلاقة حيث بليغ معامل الارتباط (9 . v.) وهي علاقة إيجابية بين بعد أسلوب المساواة وأسلوب الطلاقة، كما يتضح

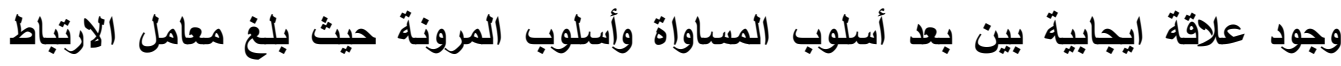

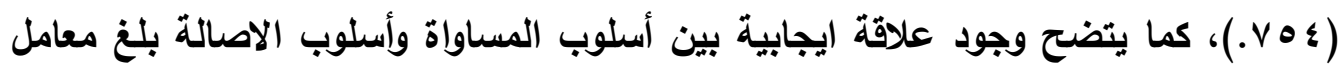
الارتباط (VAr.)، ويالنسبة لبعد أسلوب المساواة وأسلوب إدراك التفاصيل توجد علاقة

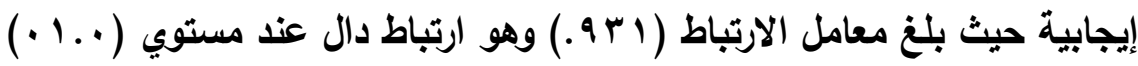
كما يوضح جدول رقم (11) وجود علاقة عكسية بين الأساليب السلبية للمعاملة الوالدية وابعاد مستوي التفكير الابتكاري لاي الموهويين ذوي صعويات التعلم حيث بلغ معامل الارتباط

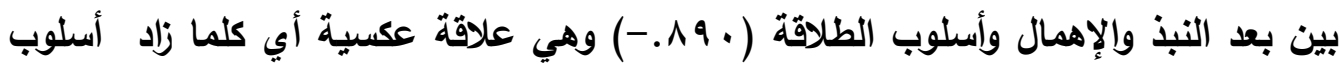
النبذ والإهمال انخفض مستوي الطلاقة لاي الموهويين ذوي صعويات التعلم ، كما يتضح وجود علاقة عكسية سلبية بين بعد أسلوب النبذ والاهمال وأسلوب المرونة حيث بلغ معامل

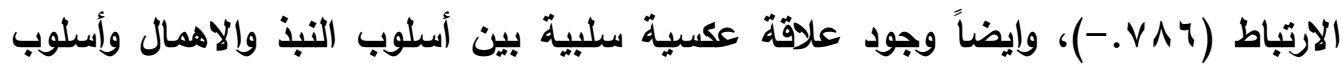

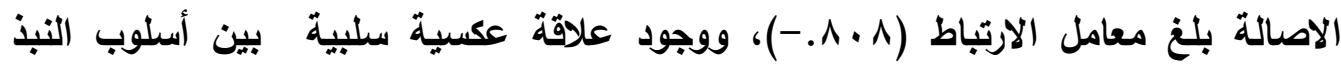
والإهمال وإدراك التفاصيل بمعامل ارتباط (لvV9.VV9) ويالنسبة لبعد الحماية الزائدة وأسلوب الطلاقة حيث بلغ معامل الارتباط (هVq.oV9) وهي علاقة عكسية سلبية بين بعد أسلوب الحماية الزائدة وأسلوب الطلاقة، كما يتضح وجود علاقة ايجابية بين بعد أسلوب الحماية

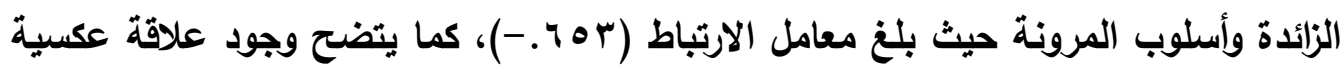
سلبية بين أسلوب الحماية الزائدة وأسلوب الاصالة بلغ معامل الارتباط ( .VA. (-)، ونجد أيضا

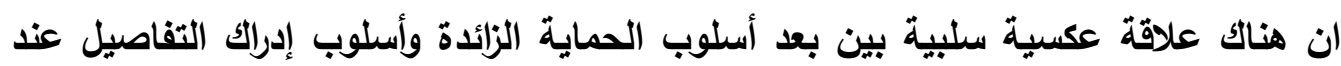

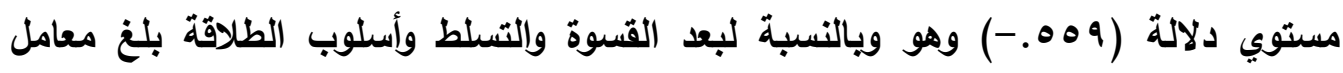

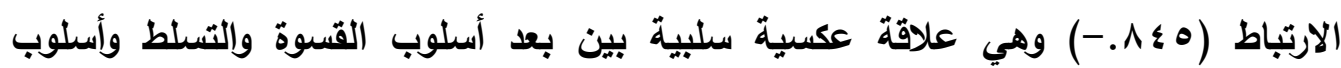

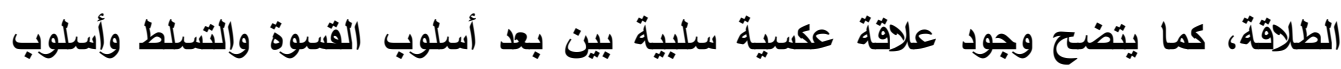
المرونة حيث بلغ معامل الارتباط (VA9

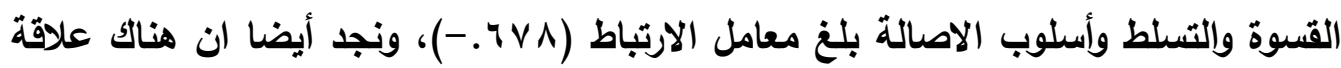


عكسية سلبية بين بعد أسلوب القسوة والتسلط وأسلوب إدراك التفاصيل عند مستوي دلالة

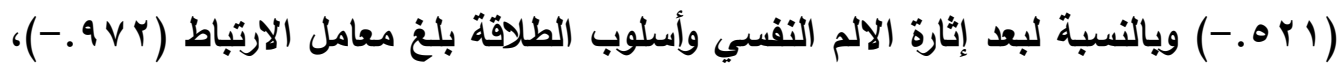
وهي علاقة ايجابية بين بعد إثارة الالم النفسي وأسلوب الطلاقة، كما يوضح الجدول وجود علاقة عكسية سلبية بين بعد إثارة الالم النفسي وأسلوب المرونة حيث بلغ معامل الارتباط

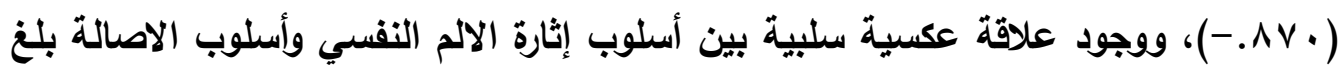
معامل الارتباط (VYT. VY) وأيضا يوضح الجدول وجود علاقة لإيجابية بين أسلوب إثارة الالم

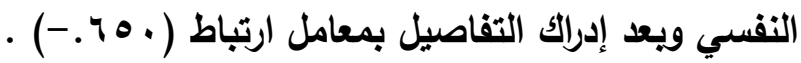
وهكذا نستخلص وجود علاقة ارتباطية إيجابية دال احصائياً عند مستوي (0.01) بين الأساليب الإيجابية للمعاملة الوالدية وأساليب مستوي التفكير الابتكاري لدي الموهوبين

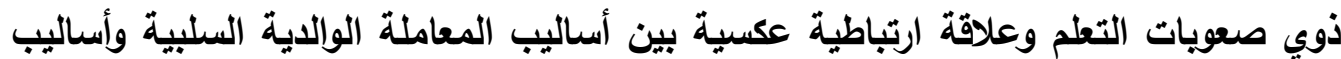
مستوي التفكير الابتكاري لدي الموهويين ذوي صعويات التعلم، وتتفق هذه النتيجة مع دراسة

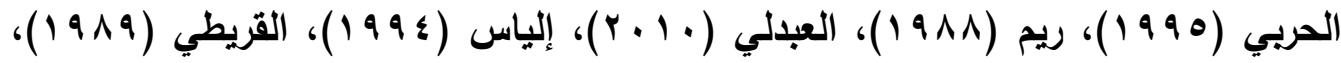
Ritchotte, Jennifer A.; Zaghlawan, Hasan Y, Park, Soeun; ( $($. 19) eL aL.

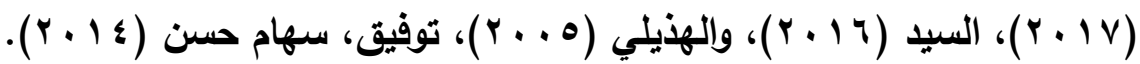
- نص الفرضية الثانية: - توجد أساليب للمعاملة الوالدية الإيجابية والسلبية أكثر استخداما وشيوعا لاي الوالدين مع الموهوبين ذوي صعويات التعلم. وللإجابة عن هذا الفرض تم استخراج المتوسط الحسابي والانحراف المعياري للتعرف على متوسط درجات استجابات الوالدين على عبارات استبيان المعاملة الوالدية كما هو موضح في جدول رقم (ب ا ). 


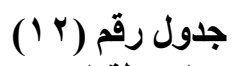

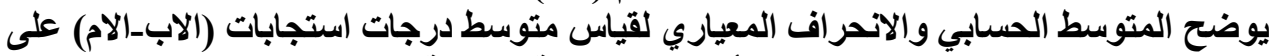
استبيان أساليب المعاملة الوالدية

\begin{tabular}{|c|c|c|c|c|c|c|}
\hline الترتيب & النسبة المئوية & S & العينة & الوالدين & الابعاد & الرقم \\
\hline$\varepsilon$ & $\%$ & $r v$ & 09 & الاب & \multirow{2}{*}{ والاهتبل } & \multirow[t]{2}{*}{1} \\
\hline$r$ & $\% 9$. & or & 89 & الام & & \\
\hline 0 & $\% \otimes \wedge$ & & 89 & الاب & \multirow[t]{2}{*}{ الايمقر اطية } & \multirow[t]{2}{*}{$r$} \\
\hline$r$ & $\% \vee 7$ & $\leqslant 0$ & 89 & الام & & \\
\hline 1 & $\% \wedge r$ & $\leqslant 9$ & 09 & الاب & \multirow{2}{*}{ والتكافِّة } & \multirow[t]{2}{*}{$r$} \\
\hline 1 & $\% 90$ & 07 & 09 & الام & & \\
\hline$r$ & $\% 77$ & $r q$ & 09 & الاب & \multirow[t]{2}{*}{ المساواة } & \multirow[t]{2}{*}{$\varepsilon$} \\
\hline$\varepsilon$ & $\% \vee 1$ & $\leqslant r$ & 09 & الام & & \\
\hline r & $\% 79$ & $\leqslant 1$ & 09 & الاب & \multirow{2}{*}{ والإلهمال } & \multirow[t]{2}{*}{0} \\
\hline 0 & $\% \circ 9$ & ro & 09 & الام & & \\
\hline 7 & $\% \leqslant 9$ & rq & 09 & الاب & \multirow{2}{*}{ الزائداية } & \multirow[t]{2}{*}{7} \\
\hline 7 & $\%$ or & $\mu$ & 09 & الام & & \\
\hline$\Lambda$ & $\%$ \%r & 19 & 09 & الاب & \multirow{2}{*}{ أسلوب } & \multirow[t]{2}{*}{ V } \\
\hline$\Lambda$ & $\%$ Y & $1 \varepsilon$ & 09 & الام & & \\
\hline V & $\% \leq V$ & $r \wedge$ & 09 & الاب & \multirow{2}{*}{ الألم النفسي اثارة } & \multirow[t]{2}{*}{$\wedge$} \\
\hline $\mathrm{v}$ & $\%$ ro & 10 & 09 & الام & & \\
\hline
\end{tabular}

يتضح من الجدول رقم (Y I) أن أكثر أساليب المعاملة الوالدية التي يتعامل بها الآباء مع أبنائهم الأطفال الموهوبين ذوي الصعويات خلال تنشئتهم هو أسلوب التشجيع

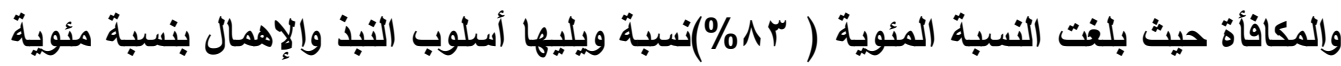
(97\%) ، ويليه أسلوب المساواة بنسبة مئوية (7 \%\%)، وجاء أسلوب التقبل والاهتمام في

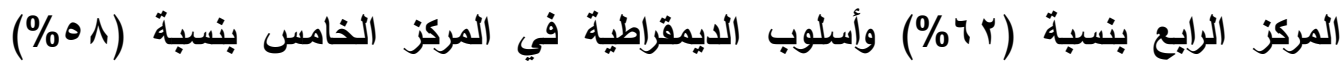

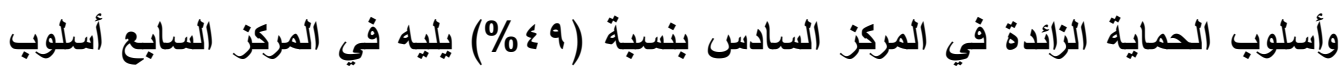

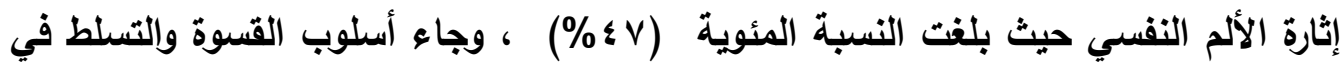
المرتبة الأخيرة بنسبة ( r r r\%) ، أما بالنسبة للأمهات فنجد ان أسلوب التشجيع والمكافأة

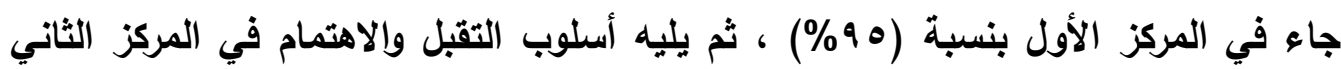




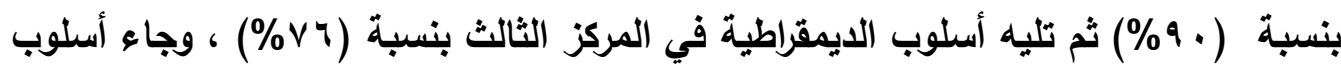

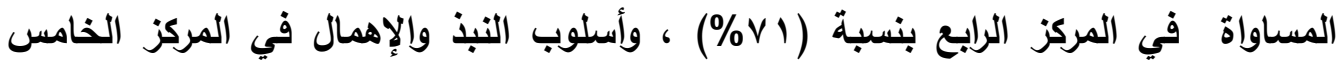
بنسبة (9॰\%) ، وأسلوب الحماية الزائدة في المركز السادس بنسبة (rه\%) ، وأسلوب إثارة الألم في المركز السابع بنسبة (ه\%\%) ، وأخر أسلوب للمعاملة يتعاملن بها الأمهات مع

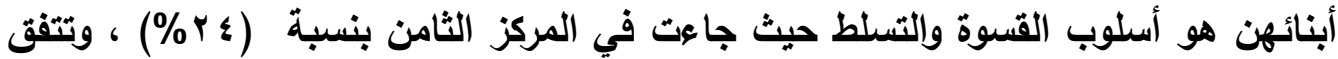

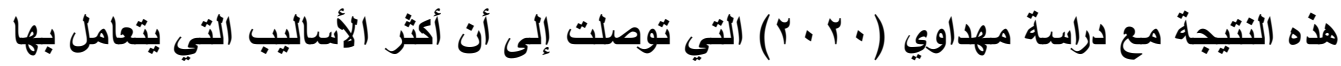

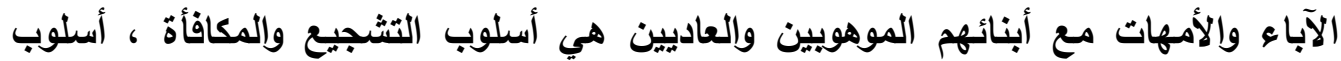
التقبل والاهتمام ، أسلوب الايمقراطية ، أما في الأساليب السلبية المتمثلة في (أسلوب النبذ

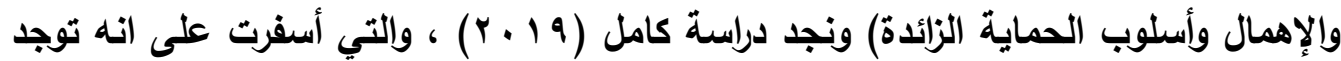

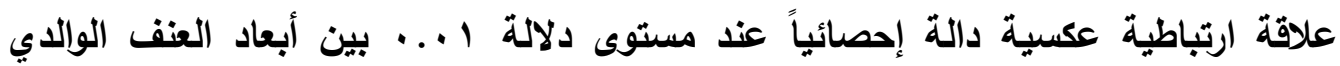
والتفكير الإبداعي لاى أطفال مرحلة الطفولة المتوسطة وهو ما اشارت اليه الدراسة الحالية من انخفاض متوسط درجات الوالدين على الأساليب السلبية مثل أسلوب القسوة والتسلط والالم النفسي - مان - - نص الفرضية الثالثة: - توجد فروق ذات دلالة إحصائية بين كلا من الاب والام في

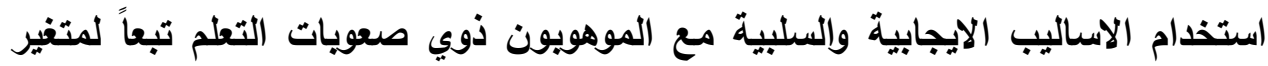
الجنس.

يوضح جدول رقم (r I ) فروق بين متوسطات درجات (الاب-الام) على ابعاد مقياس اساليب المعاملة الوالدية

\begin{tabular}{|c|c|c|c|c|c|c|}
\hline \multirow{2}{*}{ مستوي الدلالة } & \multirow{2}{*}{ ت } & \multicolumn{2}{|c|}{ الامهات =9q } & \multicolumn{2}{|c|}{ الاباء =9 ه } & \multirow[t]{2}{*}{ اساليب المعاملة الوالدية } \\
\hline & & $\varepsilon$ & م & $\varepsilon$ & م & \\
\hline داله &.$\vee \vee q$ & 2.07 & 19 & 2.50 & 17.66 & أسلوب التقبل والاهتمام \\
\hline داله & 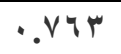 & 2.15 & 18.53 & 2.23 & 16.28 & أسلوب الايموقر اطية \\
\hline داله & $\because \vee \wedge$. & 2.56 & 22.50 & 3.08 & 19.59 & أسلوب التشجيع والمكاثأة \\
\hline غير داله & $\cdot .001$ & 1.81 & 18 & 2.22 & 18.25 & أسلوب المساواة \\
\hline داله & .891 & 2.02 & 16.06 & 3.38 & 19.34 & أسلوب النبذ والاهمال \\
\hline داله & $\because 874$ & 3.57 & 17 & 2.85 & 1Y.53 & أسلوب الحماية الزائدة \\
\hline داله & $\because .799$ & 1.95 & 11.81 & 1.97 & 14.03 & أسلوب القسوة والتسلط \\
\hline غير داله & $.1 \leqslant 9$ & 2.76 & 13.09 & 2.47 & 13.84 & أسلوب اثثارة الالم النفسي \\
\hline
\end{tabular}


يتضح من الجدول رقم (T I I إ) وجود فروق ذات دلالة إحصائية بين الأم والأب في أساليب

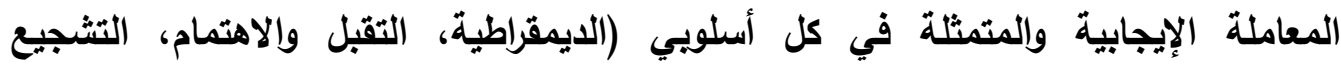
والمكافأة) لصالح الأم، ووجود فروق ذات دلالة إحصائية بين الأم والأب في بعض أساليب الإلئ

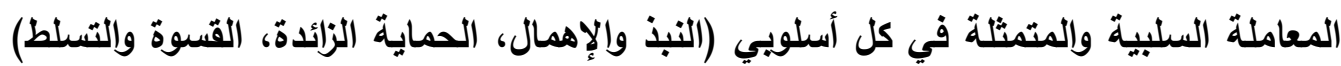
لصالح الأم بينما لم تكن هناك فروق ذات دلالة إحصائية بين أساليب المعاملة الوالدية للأطفال الموهوبين في أسلوب المساواة وإثارة الآلم النفسي. وتتفق هذه النافي النتيجة مع دراسة

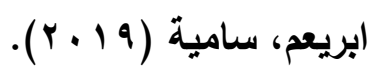

نص الفرضية الرابعة: -توجد فروق ذات دلالة إحصائية بين متوسطات درجات الموهوبين

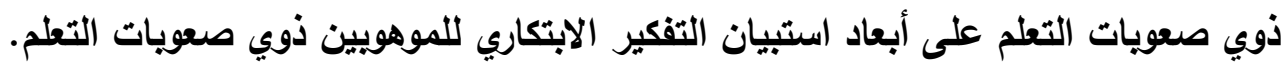
يوضح جدول رقم (؛ (1) فروق بين متوسطات درجات عينة الموهوبين ذوي صعويات التعلم على أبعاد استبيان التفكير الابتكاري

\begin{tabular}{|c|c|c|c|c|c|}
\hline \multirow{2}{*}{ مستوي الدلالة } & \multirow{2}{*}{ مستوي } & \multirow[b]{2}{*}{ 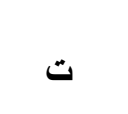 } & \multicolumn{2}{|c|}{$\bullet q=\dot{0}$} & \multirow[t]{2}{*}{ التفكير الابتكاري } \\
\hline & & & $\varepsilon$ & p & \\
\hline دال & $\varepsilon$ & $\because \cdots 0$ & $\varepsilon . \cdot r$ & $r \wedge . \vee 0$ & الطلاقة \\
\hline دال & 1 & $\because \cdot 1$ & A.Y. & rr... & المرونة \\
\hline دال & $r$ & .00 & $r .79$ & r.0. & الأصالة \\
\hline دال & $r$ & $\theta .1 \leqslant r$ & $V .7 V$ & r..OQ & إدراك التفاصيل \\
\hline
\end{tabular}

يوضح جدول رقم (\& 1) وجود فروق بين متوسطات درجات عينة الموهوبين ذوي

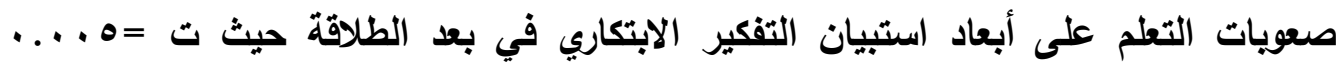

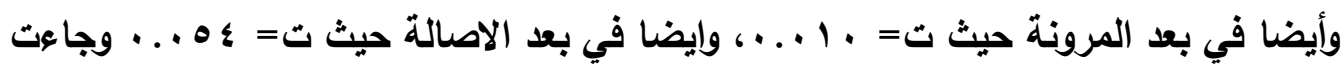

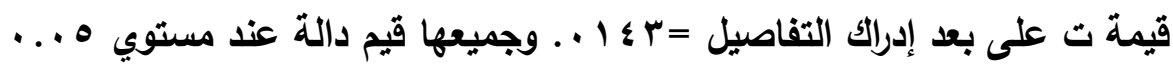
مما يشير الى فروق بين متوسطات درجات عينة الموهويين ذوي صعويات التعلم

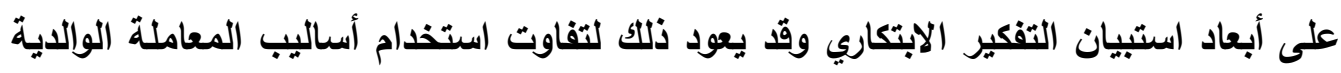
الإيجابية مع الأبناء حيث جاء ترتيب مستويات قياس التفكير الابتكاري المرونة في المركز

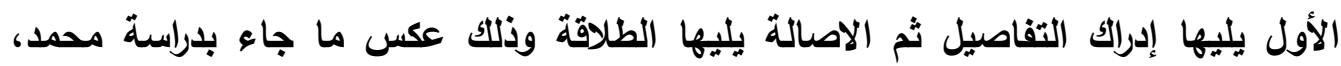




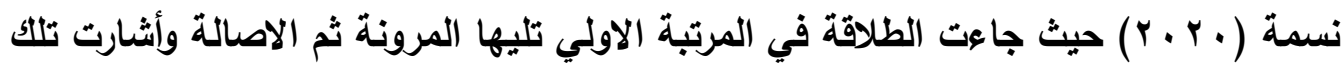
الدراسة الى عدم وجود فروق ذات دلالة إحصائية بين مستويات التفكير الإبداعي. مناقشة النتائج يتضح من خلال عرض ومناقشة الفرضيات أن الاراسة الراهنة قد حاولت تحقيق أهدافها بطرق إحصائية متعددة واستخلصنا النتائج التالية : 1 - وجود علاقة ارتباطية إيجابية دال احصائياً عند مستوي (0.01) بين أساليب المعاملة الوالدية ومستوي التفكير الابتكاري لاي الموهوبين ذوي صعويات التعلم وعلاقة عكسية

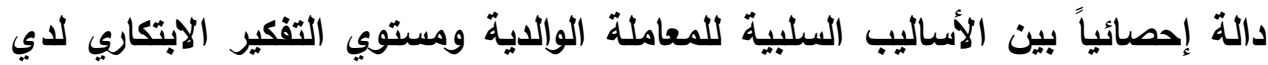
الموهويين ذوي صعويات التعلم ، ويمكن تفسير هذه لنتيجة في ضوء نظرية التحليل

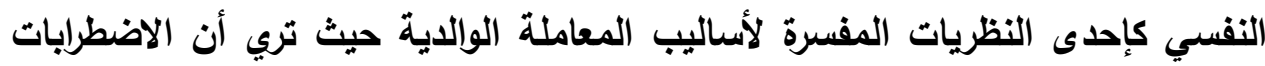

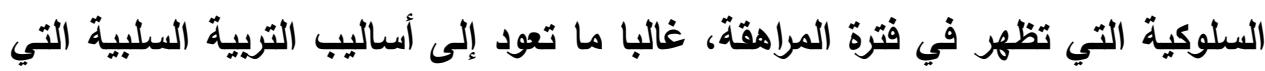
يتعرضون لها في فترة الطقولة المبكرة، التي تثبت فيها معالم الثخصية في أثناء التنشئة الاجتماعية للطقل. (بن راثد، 2014) ويلاحظ أن من إيجابيات هذه النظرية

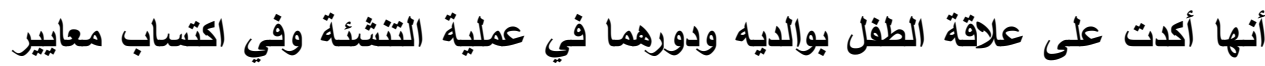

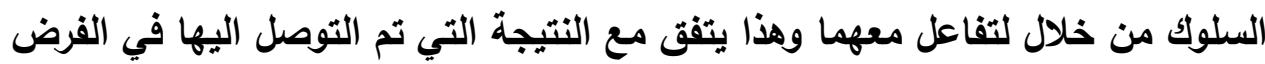
الأول والتي تشير الى وجود علاقة إيجابية ذات دلالة إحصائية بين أساليب المعاملة

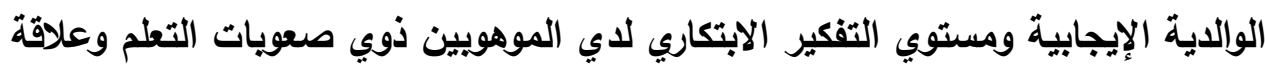
عكسية بين الأساليب السلبية للمعاملة الوالدية ومستوي التفكير الابتكاري لاي الأطفال

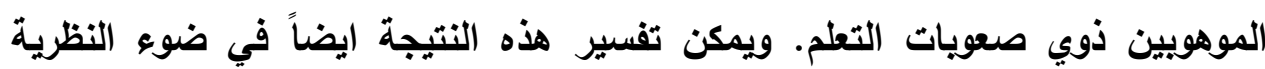
لسلوكية المفسرة للتفكير الابتكاري والتي تري ان سلوك الأطفال عبارة عن استجابات لمثيرات وهو ما يوضح ان الأساليب الإيجابية للمعاملة الوالدية إذا ما اعتبرناها مثيرات فسوف نجني من ورائها استجابات جيدة من الأطفال الموهوبين ذوي صعويات التعلم. r - أن أكثر أساليب المعاملة الوالدية التي يتعامل بها الآباء مع أبنائهم الأطفال الموهوبين

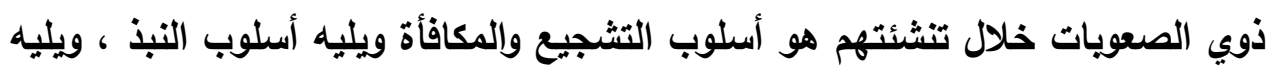
أسلوب المساواة ، وجاء أسلوب التقبل والاهتمام في المركز الرابع وأسلوب الايمقراطية

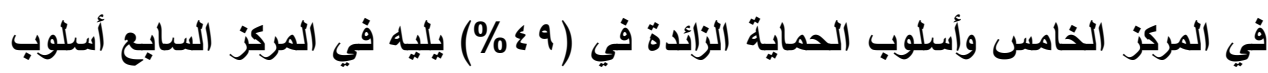


إثارة الألم النفسي ، وجاء أسلوب القسوة والتسلط في المرتبة ، أما بالنسبة للأمهات فنجد ان أسلوب التثجيع والمكافأة جاء في المركز الأول ، ثم يليه أسلوب التقبل

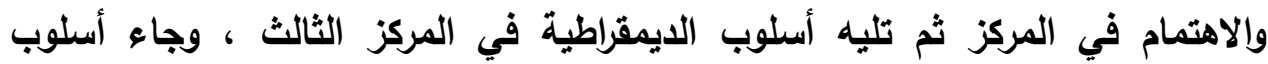

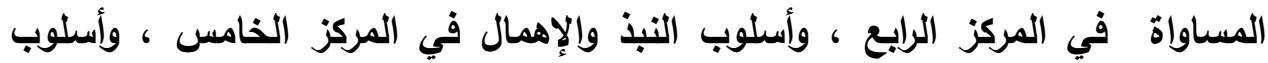
الحماية الزائدة في المركز السادس ، وأسلوب إثارة الألم في المركز السابع ، وأخر فالمابع

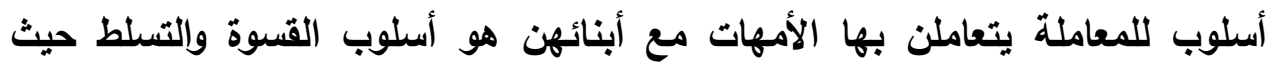

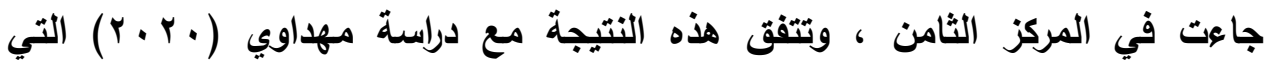
توصلت إلى أن أكثر الأساليب التي يتعامل بها الآباء والأمهات مع أبنائهم الموهوبين

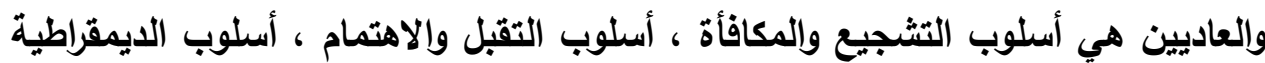
، ، أما في الأساليب السلبية المتمثلة في (أسلوب النبذ والإهمال وأسلوب الحماية

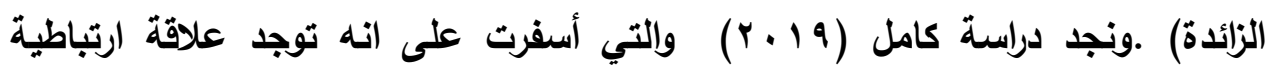
عكسية دالة إحصائياً عند مستوى دلالة ا... بين أبعاد العنف الوالاي والتفكير

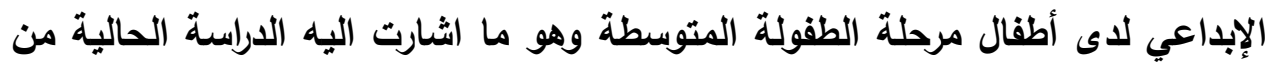
انخفاض متوسط درجات الوالدين على الأساليب السلبية حيث جاء أسلوب القسوة والتسلط والالم النفسي بمتوسطات منذفضة مقارنة بباقي الأساليب . r- توجد فروق ذات دلالة إحصائية بين كلا من الاب والام في استخدام الاساليب الايجابية

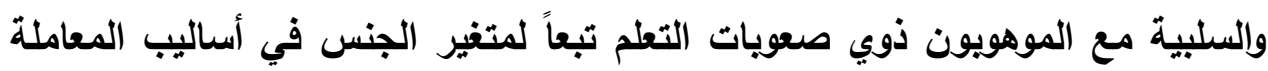
الإيجابية والمتمثلة في كل أسلوبي (الديمقراطية، التقبل والاهتمام، التشجيع والمكافأة)

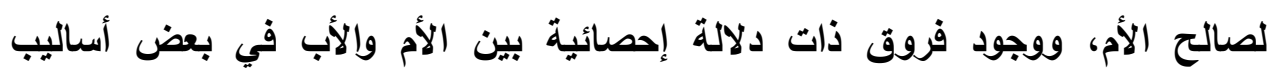

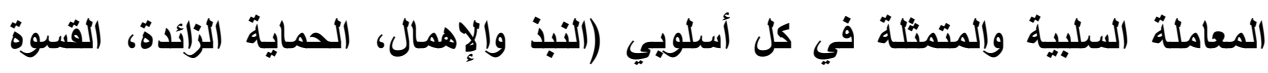

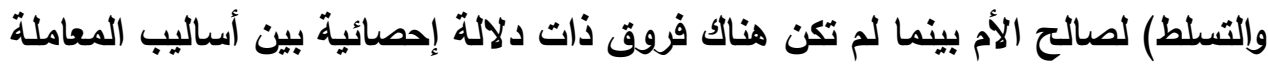
الوالدية للأطفال الموهوبين في أسلوب المساواة وإثارة الآلم النفسي. وتتفق هذه التهات النتيجة

$$
\text { مع دراسة ابريعم، سامية (9 (19 بـ). }
$$

§ - وجود فروق بين متوسطات درجات عينة الموهوبين ذوي صعويات التعلم على أبعاد

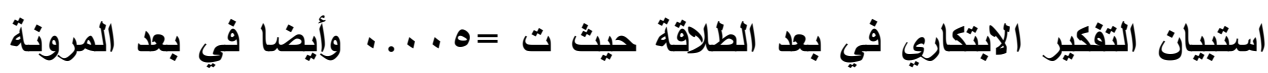

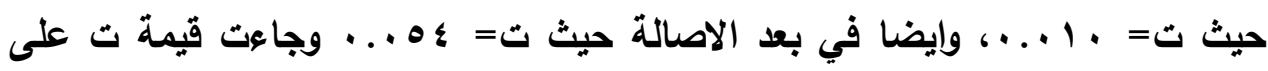




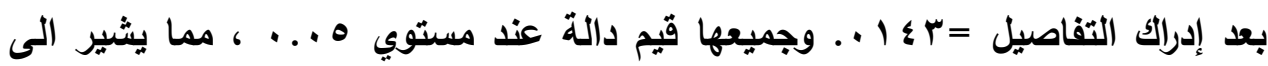
فروق بين متوسطات درجات عينة الموهوبين ذوي صعويات التعلم على أبعاد استبيان

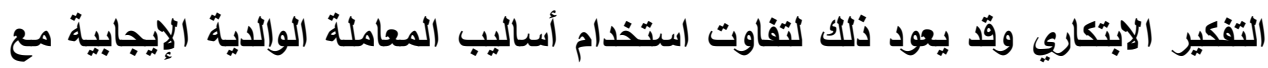
الأبناء حيث جاء ترتيب مستويات قياس التفكير الابتكاري المرونة في المركز الأول يليها إدراك التفاصيل ثم الاصاية يليها الطلاقة وذلك عكس ما جاء بدراسة محمد، نسمة

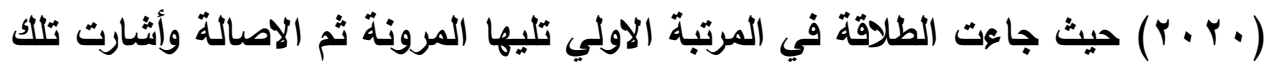
الدراسة الى عدم وجود فروق ذات دلالة إحصائية بين مستويات التفكير الإبداعي.

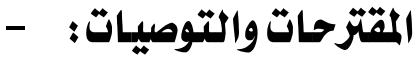

من خلال نتائج الدراسة الحالية يمكن تقديم التوصيات والمقترحات التالية: - القيام بدراسات مستقبلية وافية حول سبل تعزيز أساليب المعاملة الوالدية الإيجابية -القيام بدراسات مستقبلية حول دعم الأطفال الموهويين ذوي صعويات التعلم. - تطوير الرعاية العلاجية والتعليمية لفئة الموهويين ذوي الصعويات بهدف احداث تنمية مجتمعية - مساعدة هؤلاء الأطفال على إزالة الموانع المحتملة لإمكاناتهم القائمة على المشاريع الفردية. وقبول التفرد والاختلاف في الأطفال حتى يمكن أن يسهم في التسامح وتنمية الإبداع، لصالح المجتمع -على الآباء والأمهات أن يتسموا بالتسامح والمبادئ الأخلاقية العالية والبعد عن العقاب والأساليب الأكثر تسلطاً.

-إن توفير الأمن النفسي من خلال أساليب تنشئة إيجابية للطفل يقوّي لايه ملكات الابتكار. -دراسة العلاقة بين أساليب المعاملة الوالدية والقدرات العقلية الأخرى كالاكاء لاي فئية الموهويين ذوي صعويات التعلم. - دراسة العلاقة بين أساليب المعاملة الوالدية والصحة النفسية للموهوبين ذوي صعويات التعلم. - ضرورة تقديم خدمات الارشاد النفسي للوالدين وللأطفال الموهوبين ذوي صعويات التعلم. 
- توعية آباء الطلاب بأهمية اتباع أسلوب الديمقراطية، التشجيع والمكافأة عند كلا من الإباء والامهات مما يساعد على دعم التفكير الابتكاري لاى الأبناء من التلاميذ الموهوبين ذوي صعويات التعلم. -على وسائل الإعلام القيام بدورها في التعريف بكيفية التعامل مع الطلاب المبتكرين.

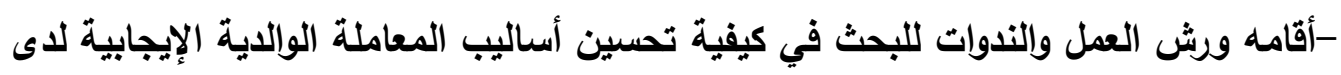

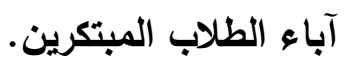




\section{المراجع}

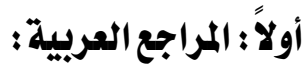

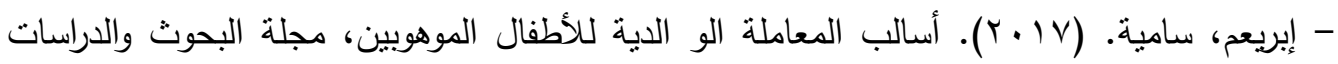

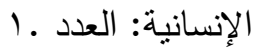

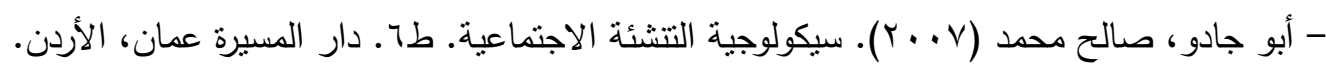
- أبو حسين، عبد العزيز (2014) درجة امتلاك معلمى الطلاب الموهويين للكفايات المهنية والاجتماعية اللازمة من وجهة نظرهم ببحافظة جدة .رسالة ماجستير غير منشورة، كلية التربية-

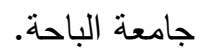

- أحمد غراب، هشام. (10 • ب). الصحة النفسية للطفل. طا ـ دار الكتب العلمية. بيروت. لبنان. - العيسوي، عبد الفتاح محمد. (991)). سيكولوجية اللعب ودوره التربوي. مجلة التربية، العدد

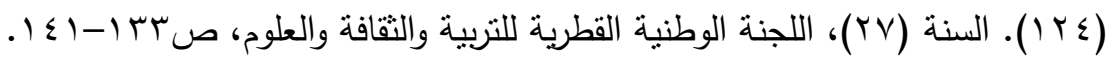
-الثريف، شيخة سعيد. (ع^91) المعاملة الو الدية وعلاقتها بالتحصيل الدراسي للفتاة المراهقة بالمرحلة المتوسطة؟ رسالة ماجستير جامعة الرياض.

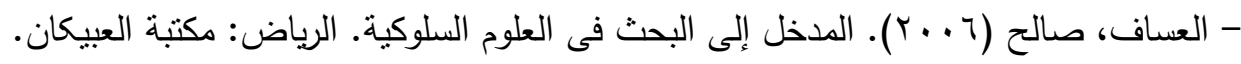

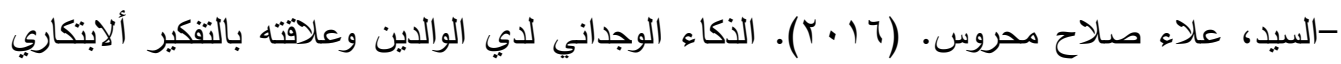

لدي الأبناء. اطروحة ماجستير • جامعة عين شمس - معهد الطفولة - قسم الدراسات النفسية.

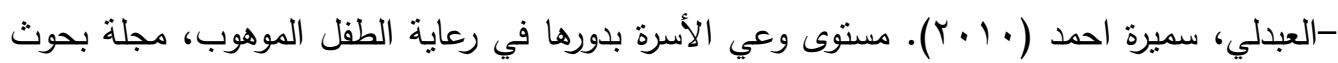

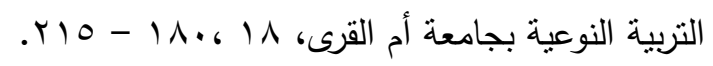
-القريطي، عبد المطلب أمين (919 (1)). المتقوقون عقلياً: مشكلاهم في البيئة الأسرية والمدرسية ودور

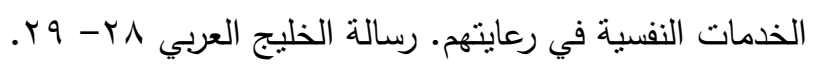
- الوكيل، عبد الحكيم عبد العزيز • (919 (1). الاتجاهات الوالدية وعلاقتها بالتحصيل الدراسي والتفكير الابتكاري. رسالة ماجستير غير منشورة، جامعة الملك سعود، الرياض، المملكة العربية السعودية.

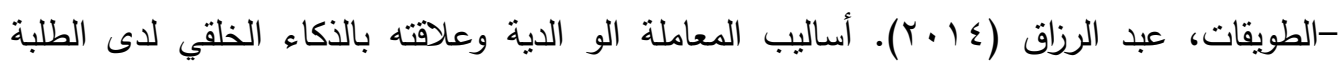
الموهوبين في مدرسة الملك عبد اله الثاني للتمبيز في محافظة البلقاء. رسالة ماجستير، جامعة البلقاء النطبيقية. - الحسين، إبراهيم عبد الكريم. (ץ + . ץ). إعداد الطفل للتفوق "هنظور تربوي معلوماتي لتتمية القدرات

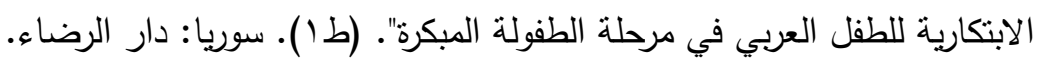

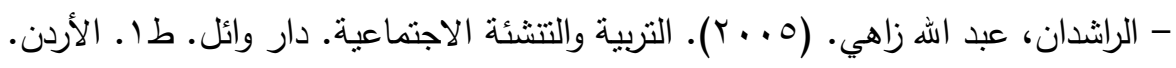


- المقاطي، طعيس. (1) • (ץ). أساليب التتشئة الاجتماعية. طا، فهرس مكتبة الملك فهر الوطنية، الرياض.

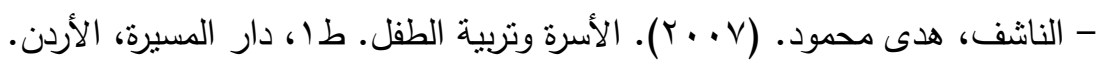

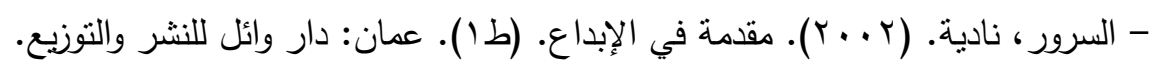

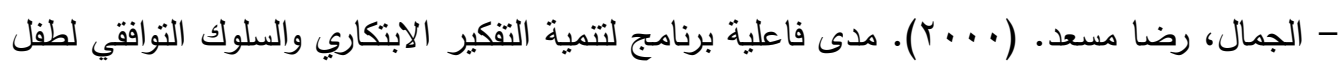

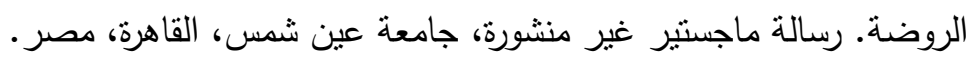

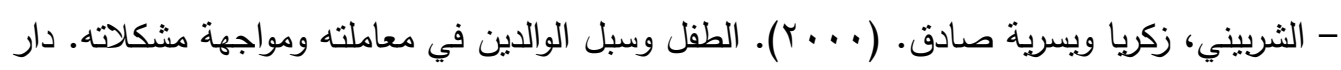
الفكر العربي، القاهرة.

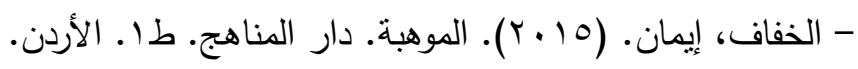

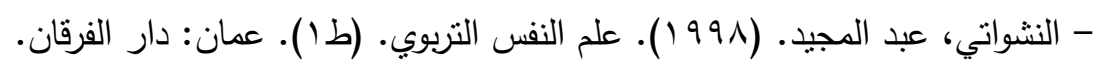

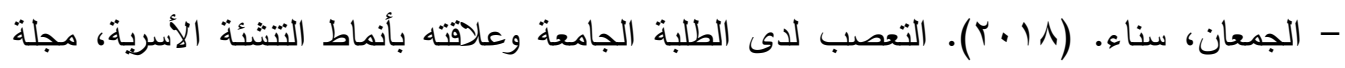

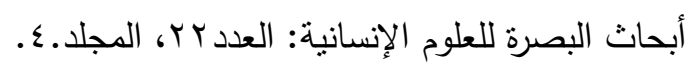

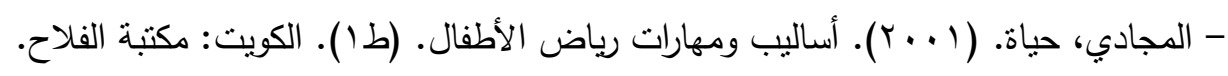

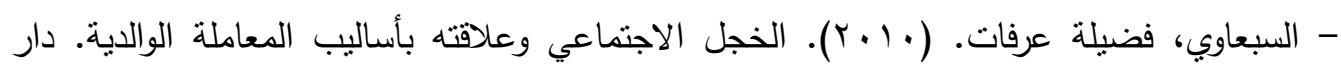
صفاء. طا ـ الأردن.

-إلياس، فاديا سابا (ـ991). الفروق في المشكلات والحاجات الإرشادية بين الطلبة المتميزين وغير المتميزين. رسالة ماجستير غير منشورة، الجامعة الأردنية، عمان، الأردن.

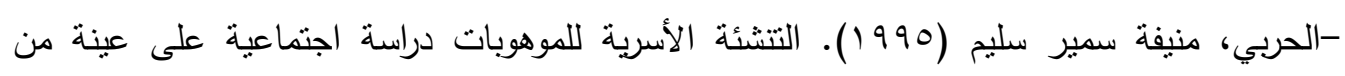
أمهات الموهوبات والعاديات بمدينة الرياض، رسالة ماجستير غير منشورة. جامعة الملك سعود، الرياض، السعودية.

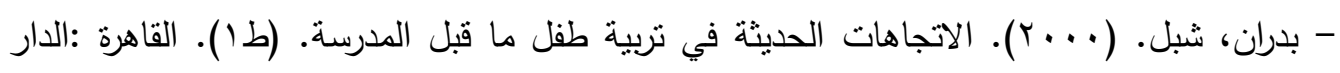
المصرية اللبنانية. - بركات، آسيا. (.... (ب). العلاقة أساليب المعاملة الو الدية والاكتئاب لاى بعض المراهقين

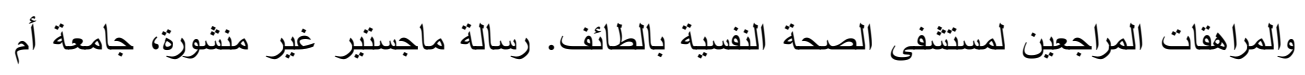

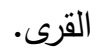

- بهادر، سعدية محمد. (r . . r). برامج تربية أطفال ما قبل المدرسة. (ط ). عمان: دار المسيرة. 
- بن راثند، ناصر بن محمد (؟ ( ب). اساليب المعاملة الوالدية كما يدركها الابناء وعلاقتها بالاتزان

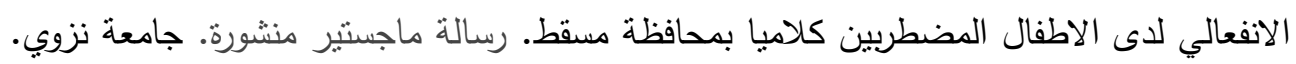

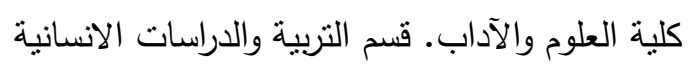

-توفيق، سهام حسن. (ع ( ـ ب). اساليب المعاملة الوالدية كما يدركها الأبناء وعلاقتها بالتفكير الابتكاري لدى طلاب المرحلة الثانوية. ماجستير علم النفس التربوي. جامعة أفريقيا العالمية. كلية التربية،

$$
\text { محلية الخرطوم - وحدة الخرطوم شرق. }
$$

- جروان، فتحي عبد الرحمن. (999 (1)). تعليم التقكير مفاهيم وتطبيقات. (ط ()). العين: دار الكتاب

$$
\text { الجامعي. }
$$

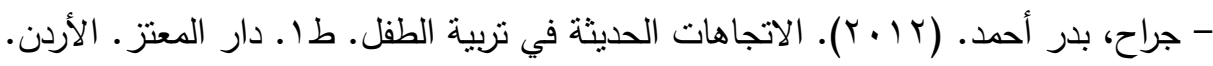

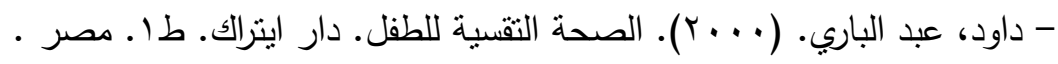

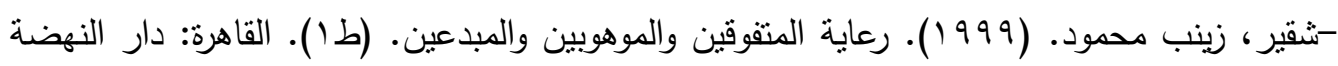
العربية.

- صادق، آمال وأبو حطب، فؤاد. ( •99 19). علم النفس التربوي. القاهرة: مكتبة الأنجلو المصرية.

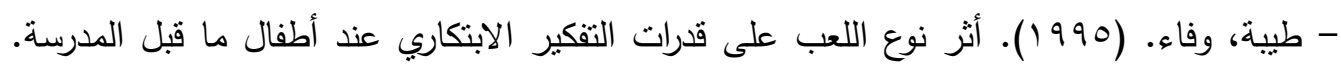
رسالة ماجستير غير منشورة، جامعة الملك سعود، الرياض، المملكة العربية السعودية.

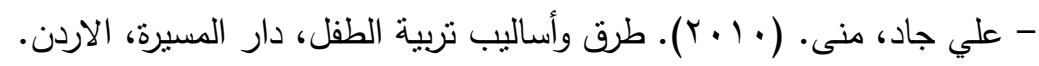

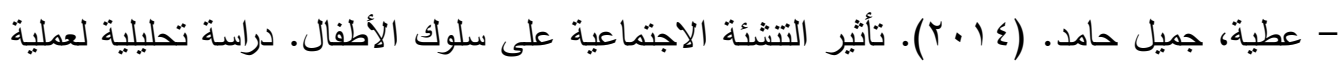
النتشئة الاجتماعية. - عويس، عفاف أحمد. (ب99 (1). الطفل المبدع: دراسة تجريبية باستخدام الدراما الإبداعية(ط ().

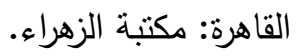
- غنام، صليحة. (· ( • ( ). عمالة الأطفال وعلاقتها بالظروف الأسرية. رسالة ماجستير غير منشورة، جامعة باتتة. - عدس، محمد عبد الرحيم ومصلح، عدنان عارف. (999 (1). رياض الأطفال. (طץ). عمان :دار الفكر للطباعة. - عشوي، مصطفى. (1991). تربية القدرات الابتكارية لاى الطفل نحو تتاول تكاملي. مجلة التربية،

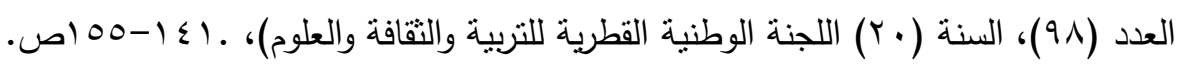

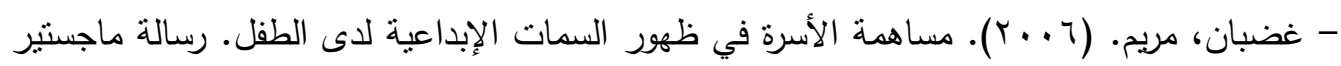
غير منشورة، جامعة قسنطينة. 


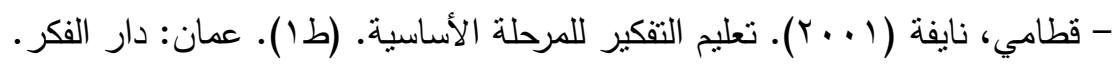

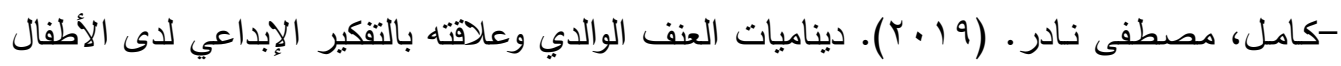

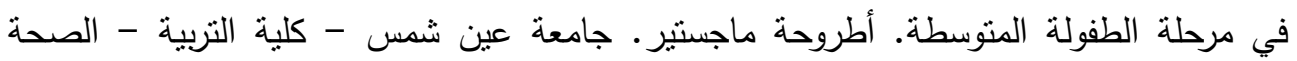
النفسية والإرشاد النفسي. مافه

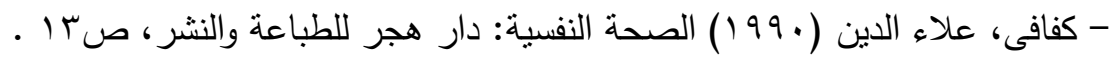

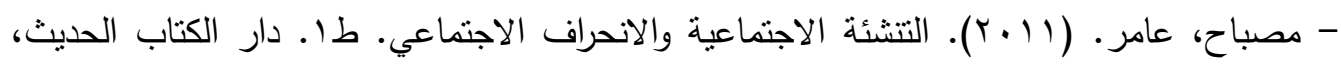

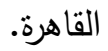

- معوض، خليل ميخائيل. (r/911). قدرات وسمات الموهوبين. (ط ). الإسكندرية: دار الفكر الجامعي.

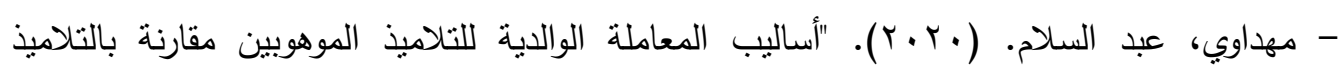

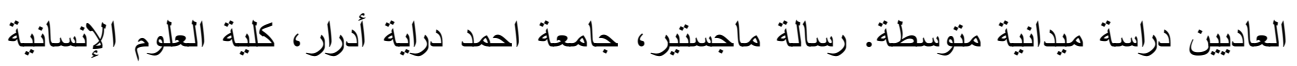
والاجتماعية والعلوم الإسلامية، الجزائر - مرزوق، عبد الحميد مرزوق. (1991). عوامل تتمية التفكير الإبداعي في مرحلة الطفولة المبكرة. المؤتمر السنوي الرابع للطفل المصري، مركز دراسات الطفولة، جامعة عين شمس، المجلد الثاني. - مقحوت، فتيحة. (ع ( ـ ؟). أساليب المعاملة الو الدية للمراهقين المتفوقين في شهادة التعليم المتوسط. رسالة ماجستير ، جامعة بسكرة.

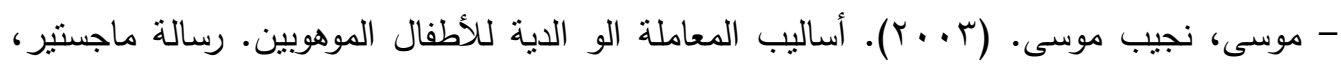
جامعة حلوان. - محمد، دعاء صادق. (999 (1). أثر ممارسة النشاط الدرامي على تتمية التفكير الابتكاري لاى الأطفال ضعاف السمع. رسالة ماجستير غير منشورة، جامعة عين شمس، القاهرة، مصر .

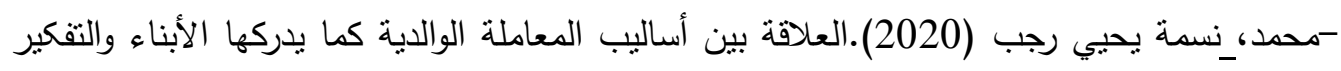

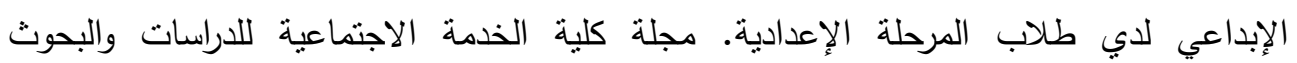

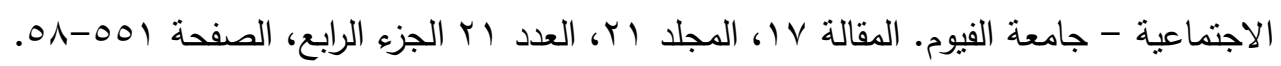

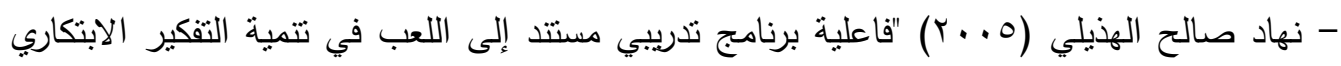

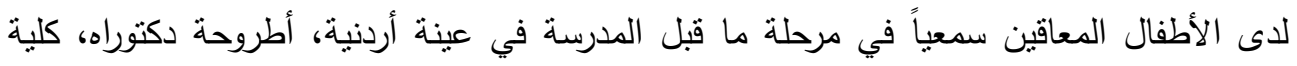
الدراسات العليا الجامعة الأردنية. 
- يس، جيهان أبو ضيف. (1 (ب). برنامج مقترح لتتمية قدرات التفكير الابتكاري لاى عينة من

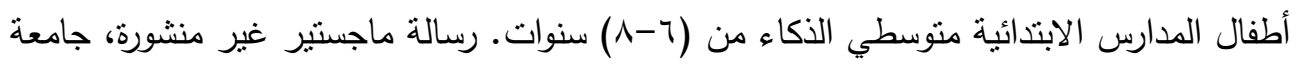

عين شمس، القاهرة، مصر .

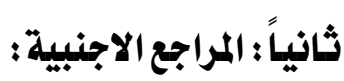

- Assouline, S.G.; Foley Nicpon, M.; \& Huber, D.H. The impact of vulnerabilities and strengths on the aca-demic experiences of twiceexceptional students: A message to school counselors. Sch. Couns.2006,10, $14-24$.

Besnoy, Kevin D.; Sosnowska, Nicole C.; Newman, Jane L.; et al (2015).-

- Coleman, M.R.; Harradine, C.; Williams King, E. (2015) Meeting the needs of students who are twice exception-al. Teach. Except Child.,38, 5-6.

-Gierczyk, Marcin; Hornby, Garry.2021." Twice-Exceptional Students: Review of Implications for Special and Inclusive Education" EDUCATION SCIENCES Volume: 11

Issue:2 Article Number: 85. :

- Isenberge, M. H. (1999). Creative and Mental Growth. Canada: Ottawa University.

Katya, A. (1998). "Creativity and Cultivation". Child Development, 3, 35-40.-

-Neilson, M. (2002). Gifted students with learning disabilities: Recommendations for identification and programming. Exceptionality, A Special Education Journal,10(2).

- Park, Soeun; Foley-Nicpon, Megan; Choate, Alyssa; eL aL. (2018) GIFTED CHILD QUARTERLY.P.309-319. Issue,3. Volume:62.

- Reis, S.M.; Baum, S.M.; Burke, E. An Operational Definition of TwiceExceptional Learners. Gift. Child. Q.2014,58, 217-230.

- Ritchotte, Jennifer A.; Zaghlawan, Hasan Y. (2019)." Coaching Parents to Use Higher Level Questioning with Their Twice-Exceptional Children ". GIFTED CHILD QUARTERLY. 1 • 1 _ᄉ 7 P.63 Volume. Issue:2 :

-Rimm, Sylvia (1988). Family Environments of Underachieving Gifted Students, Gifted Child Quarterly. 32(4), 353-359.

- Torrance, E. P. (1976). Guiding Creative Talent. New York: Robert E. Krieger Publishing Company, Huntington.

-Yewchuk, C.; Lupart, J.L. Gifted handicapped: A desultory duality. International Handbook of Research and Development of Giftedness and Talent; Heller, K., Monks, F.J., Passow, A.H., Eds.; Pergamon: New York, NY, USA, (2019). 709-725.-

-Wakefield, F. (1998). Is Creative Thinking Normally Distributed? Paper Presented at The Annual Meeting of the Southeastern Psychological Association. New Orleans. 